Portland State University

PDXScholar

Spring 6-30-2015

\title{
Defining the Terroir of the Columbia Gorge Wine Region, Oregon and Washington, USA Using Geographic Information Systems (GIS)
}

Hilary Whitney

Portland State University

Follow this and additional works at: https://pdxscholar.library.pdx.edu/open_access_etds

Part of the Geology Commons, Soil Science Commons, and the Viticulture and Oenology Commons Let us know how access to this document benefits you.

\section{Recommended Citation}

Whitney, Hilary, "Defining the Terroir of the Columbia Gorge Wine Region, Oregon and Washington, USA Using Geographic Information Systems (GIS)" (2015). Dissertations and Theses. Paper 2396.

https://doi.org/10.15760/etd.2393

This Thesis is brought to you for free and open access. It has been accepted for inclusion in Dissertations and Theses by an authorized administrator of PDXScholar. Please contact us if we can make this document more accessible: pdxscholar@pdx.edu. 
Defining the Terroir of the Columbia Gorge Wine Region, Oregon and Washington, USA

Using Geographic Information Systems (GIS)

by

Hilary Whitney

A thesis submitted in partial fulfillment of the requirements for the degree of

\author{
Master of Science \\ in \\ Geology
}

Thesis Committee:

Scott Burns, Chair

Adam Booth

Alan Busacca

Portland State University

2015 


\section{ABSTRACT}

The Columbia Gorge Wine Region (CGWR) is an emerging wine producing in Oregon and Washington State in which the number of vineyards, wineries and physical terroir conditions have yet to be defined. The CGWR extends for about 100km along the Columbia River and includes the Columbia Gorge American Viticultural Area (AVA) and the southwest portion of the Columbia Valley AVA. To better understand the physical factors affecting Oregon and Washington wine, this project analyzes the climate, topography, geology and soil at vineyards in the CGWR. This was accomplished using Geographic Information Systems, existing earth science databases and field work. As of September 2013, the region is home to 82 vineyards, 513 hectares (1268 acres), 36 wineries and 41 different varieties of Vitus Vinifera. Vineyards range in elevation from 29 to 548 meters (95 to 1799 feet).Vintner responses to a grower's survey suggest that 28 grape varieties account for $98 \%$ of the estimated grape variety acreage, with Pinot Noir being the most widely planted grape variety in both AVAs.

The boundaries of each climatic regime were mapped based on 1981-2010 PRISM data, the Winkler Index (Amerine and Winkler, 1944) updated by Jones et al. (2010) and climatic maturity groupings designed for Oregon (Jones et al., 2002; Jones et al., 2010). Three Winkler climate regimes are represented within the CGWR, including Regions Ia, Ib, and II from the Winkler Index (Jones et al., 2010). The diversity in regimes allows for a diversity of grape varieties to be planted within the regime. The average growing season temperatures and growing degree days, respectively, from $1981-2010$ calculated for vineyards ranges from $13.7^{\circ} \mathrm{C}\left(55.7^{\circ} \mathrm{F}\right)$ to $17.7^{\circ} \mathrm{C}\left(63.9^{\circ} \mathrm{F}\right)$ and 
871 for ${ }^{\circ} \mathrm{C}\left(1567\right.$ for $\left.{ }^{\circ} \mathrm{F}\right)$ to 1664 for ${ }^{\circ} \mathrm{C}\left(2994{ }^{\circ} \mathrm{F}\right)$ respectively. $58 \%$ of the vineyards are characterized in an intermediate climatic regime, 29\% are within a cool climatic regime, $9 \%$ are within a warm climatic regime and $4 \%$ are on the boundaries between a cool, intermediate or warm regime. $80 \%$ of the vineyards are within Regions Ia and Ib characterized by the Winkler Index, and 20\% are within Region II. The growing degrees days calculated for the CGWR are similar those measured in the Willamette Valley, Oregon, Burgundy, France, Umpqua Valley AVA in Oregon and Bordeaux wine region in France.

All of the soils used to grow grapes are well-drained, within a xeric moisture regime, which is favorable for viticulture. 30 soil series are represented among the vineyard sites, with the Chemawa Series (Underwood Mountain) and Walla Walla Series (eastern portions) being the dominant soil series. Majority of the soils contain a silt loam texture. Soil Survey data for Oregon and Washington suggest that loess is extensive in the CGWR, with $46.5 \%$ of the total vineyard acreage planted on soils formed in loess. The Missoula Floods also greatly influenced the texture and age of the soil in this region, with skeletal textures close to the Columbia River and finer textures at higher elevations. Other common geological deposits at vineyards in the CGWR include, Quaternary Basalt (19.6\%), Missoula Flood deposits (9.1\%), The Dalles Formation (8.0\%), Columbia River Basalt Group (7.5\%), Pliocene Basalt (3.0\%), Quaternary Surficial deposits (3.0\%), lahars (2.3\%) and Quaternary Basaltic Andesite and Andesite (0.9\%). Common geological deposits, soil series, and climate conditions at vineyard sites vary spatially in the region, and therefore it is suggested that future work focus on separating the region 
into separate climatic sub-AVA regimes to better reflect the diversity in terroir conditions. 


\section{DEDICATION}

To my family, particularly my parents, sister and Josh,

Thank you for your encouragement and compassion on my worst of days.

Without your love, support, and patience this project would have never been accomplished. 


\section{ACKNOWLEDGMENTS}

This project would not have been performed or accomplished without Scott Burns. You have taught me so much, both within and beyond the classroom, and I feel very fortunate to have you as a mentor and a constant source for inspiration. I would like to also thank Alan Busacca for his willingness to partake as a committee member in our study. Your expertise in soils and passion for winemaking in the Columbia Gorge has added to the success of this project. To my other committee member Adam Booth, thank you for your input and much needed support during the writing stages of my thesis. This project was also completed with the help of Greg Jones at Southern Oregon University, who generously donated 400 meter PRISM data to be used in our research.

I would like to acknowledge the marketing coordinators of the Columbia Gorge Wine Association, Talia and Kate for connecting us with vintners and winery owners in the region and support in promoting our project. To the winemakers, vintners, tasting room staff and winery/vineyard owners of the CGWR, thank you for your support and participation in the growers survey, especially, Lonnie Wright of The Pines 1852, Rich Cushman of Viento Wines and Mark Wharry at Swift Water Vineyards.

Soil pits were completed by the support of 12 vineyard owners/managers, including Jack Brady at Underwood Mountain Vineyard, Franco Marchesi at Marchesi Vineyards, Becky and Bob Morus at Phelps Creek Vineyard, The Reed Family (Dick, Christie and Keely) at Wy'East Vineyards, Luke Bradford at Cor 
Cellars, Brain McCormick of Idiots Grace Vineyard and Memaloose Winery, Dennis Beeks at Chuck Ridge Vineyard, Walt Houser of Bethany in the Gorge Vineyard, Doug Graves at Graves Vineyard, Harold Haake at HD LLC (Hillside Vineyard), Eric and Bridget Nisley at Dry Hollow Vineyards, Molli and James Martin of Sunshine Mountain Vineyard. Thank you also to the PSU graduate and undergraduate students who helped to dig soil pits and complete soil profile descriptions. These students include: Ellie Brown, David Demchak, Gabi Ferreira, Heather Hurtado, Tamara Linde, Dougal Hansen, Dustin Cramer, Angela Pillar, Jacob Stone, Heather Trolley, Selicity Icefire, and Tiyana Casey.

I would also like to express my appreciation for my many wonderful friends and colleagues back home and in Portland that have supported me through graduate school, especially Nina Abdollahian, Kelly Hughes, Heather Hurtado, Kassandra Lindsey, Gabi Ferreira, Kat Barnard, Emily Jenkins, Justin Ohlschlager and Tamara Linde. Thank you for being my sound board and for inspiring me to become a better scientist and friend. Thank you again to my Mom, Dad, sister Katie, Josh and family. Your love, support and encouragement allows me to find the courage to pursue my dreams. 


\section{TABLE OF CONTENTS}

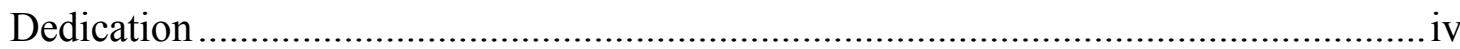

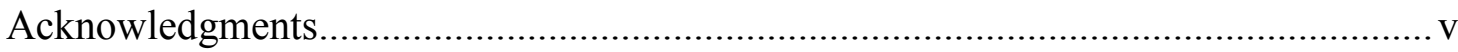

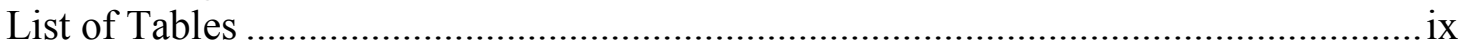

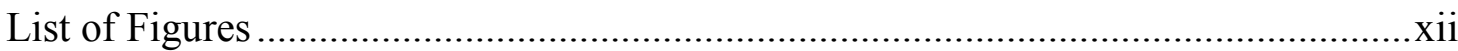

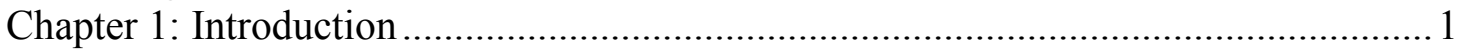

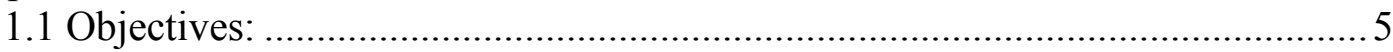

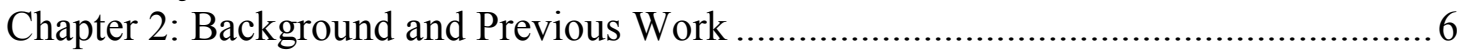

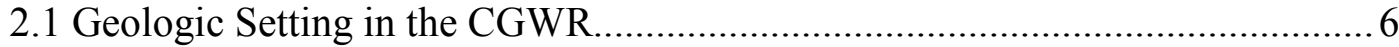

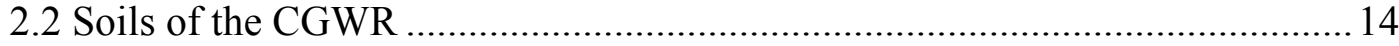

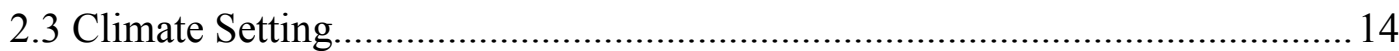

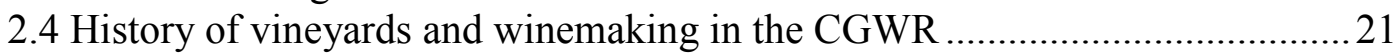

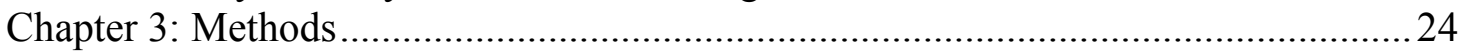

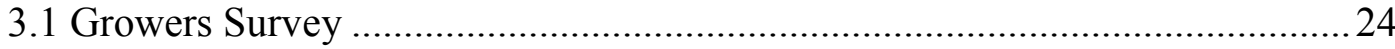

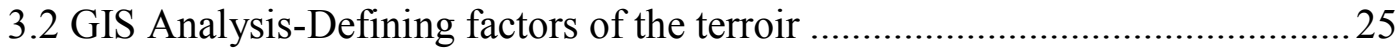

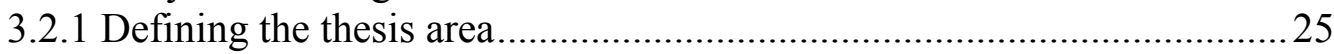

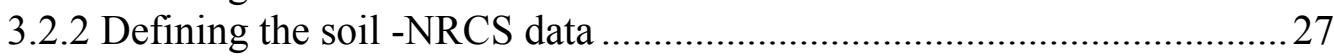

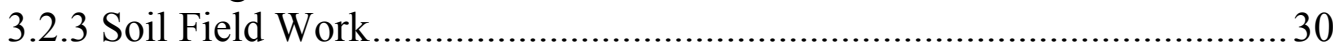

3.2.4 Soil Laboratory Work ........................................................................... 31

3.2.5 Characterizing the Geology-Geological Maps and Soil Surveys .............31

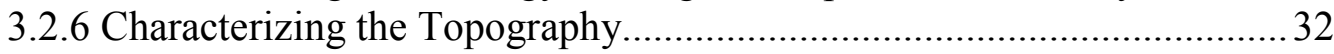

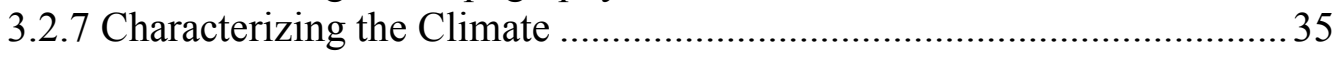

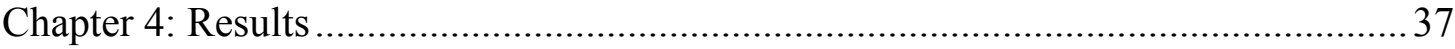

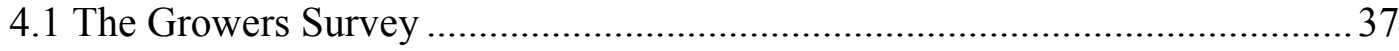

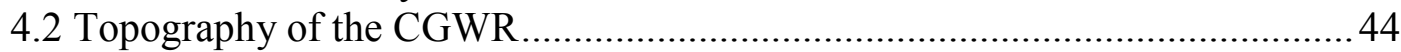

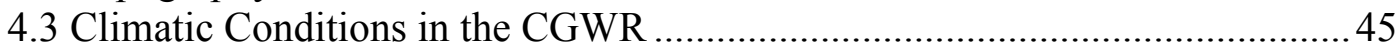

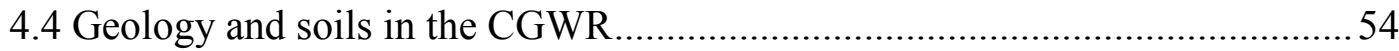

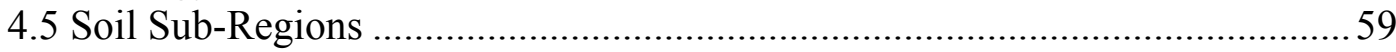

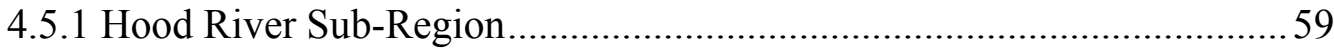

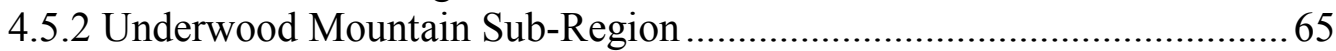

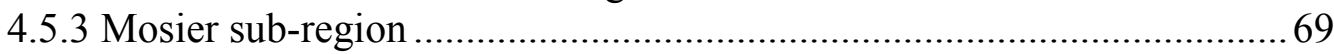

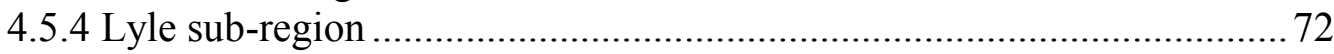

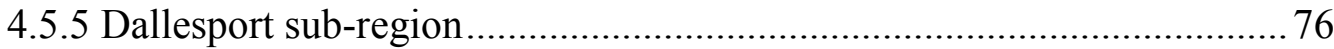

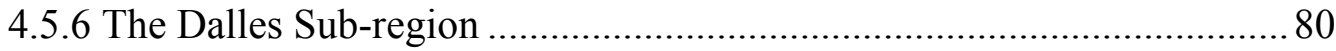

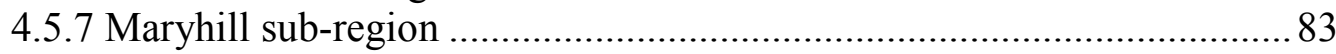

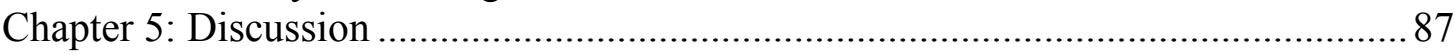

5.1 Geological Influences on Soil Development and Textures................................... 87

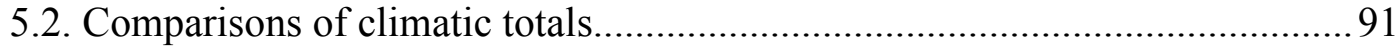

5.3 Evaluation of the Current AVA Boundaries......................................................97

5.4 Geological and Climatic Influences on Irrigation Practices ................................98

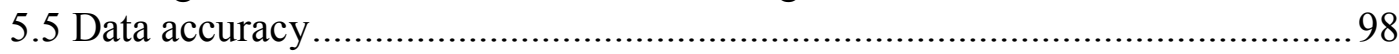

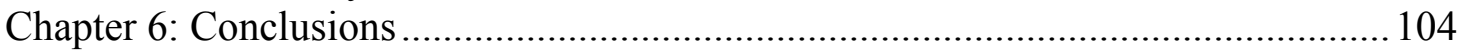

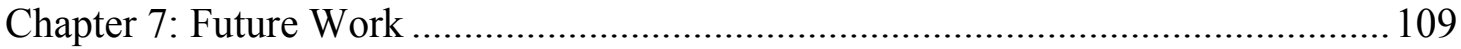




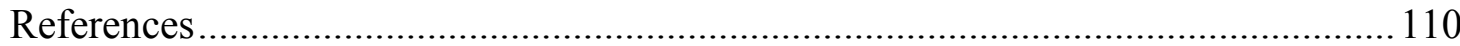

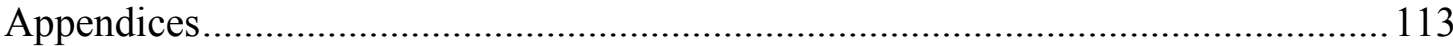

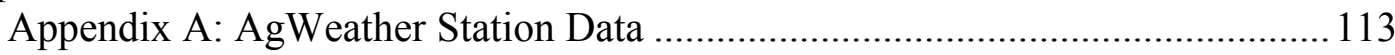

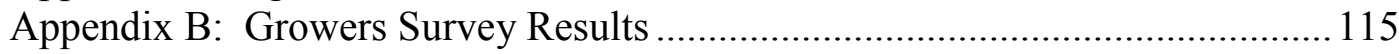

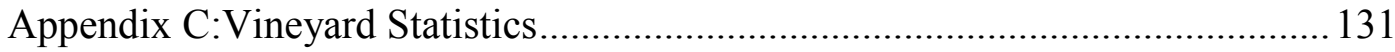

Appendix D: Soil pit field notes and descriptions ................................................ 141 


\section{LIST OF TABLES}

Number

Page

Table 1. The following equations can be used to calculate average growing season temperatures (GST)'s and growing degree day measurements (GDD). These equations are further used in this study to separate the CGWR into climate

groupings.

Table 2. Growing degree-days have been correlated with suitable grape varieties by Jones et al. (2010). Wine regions have also been compared by Jones et al. (2010) using growing degree days. Some of the more popular and regional relevant wine regions are included below.

Table 3. Loess is the dominant geological deposit underlying vineyards in the CGWR. Quaternary basalt on Underwood Mountain and in the Hood River Valley is also a common bedrock at vineyard sites. Vineyards are also commonly underlain by Missoula Flood Deposits (silts, sands and gravels), followed by The Dalles Formation, Columbia River Basalt Group, Young surficial deposits (alluvium, landslides, talus), lahar deposits (in the Hood River Valley) and Pliocene basalt and basaltic andesite.

Table 4.There are 30 soil series represented at vineyards within the CGWR. The Walla Walla Series and Chemawa Series account for over half (53.6\%) of the growing acreage in the CGWR.

Table 5. Five soil orders are represented among the vineyard soils in the CGWR

(Soil Survey Staff, 2012a, b)

Table 6. The soils in the CGWR can be classed into 9 particle size classes, with coarse-silty being the dominant texture.

Table 7. Soil series located among vineyards in the Hood River sub-region. Six soil series were mapped only among vineyards in the Hood River Valley (third column). The Oak Grove and Hood Series are the most commonly planted soil series used to plant grapes in the Hood River sub-region (fourth column). 
Table 8. Five separate soil series are mapped within the Underwood Mountain soil sub-region. All of the soils in this sub-region are volcanically-derived and contain andic properties (column 2). Majority of the vineyards are planted on the Chemawa Series or the Underwood Series (column 5). The Chemawa Series is the second most common soil series at vineyards in the entire CGWR and is represented among $17 \%$ of the total vineyard acreage (column 4). 68

Table 9. The Wamic soil series is only located at vineyards in the Mosier soil subregion. The Wind River Series is the most commonly used series for viticulture in the Mosier sub-region (column 5). The Wind Series is also mapped at Columbia Gorge Vineyard near Hood River, Oregon.

Table 10. The Balake and Gunn Series are the dominant soil series in the Lyle sub region. 74

Table 11. The Fisherhill, Dallesport, and Ewall series are mapped only at vineyard sites with the Dallesport soil sub-region. The Walla Walla series, which is dominant in the Maryhill sub-region, is also present in the Dallesport subregion.

Table 12. There are six soil series and three complex soils within The Dalles soil sub-region. The boundaries for this sub-region were drawn to include sites dominated by the Cherryhill and Chenoweth soil series.

Table 13. The Walla Walla, Quincy, Wato, Nansene and Anderly soil series dominate in the Maryhill sub-region.

Table 14. Grapes of the cool climate regime of the CGWR. The typical regime that each variety falls within is provided by Jones, 2010 . $82 \%$ of the grapes planted within the cool-climates regimes of the CGWR are typical coolclimate (or early ripening) varieties. $6 \%$ of the varieties planted within the cool-climatic regime are typical of regions of intermediate or warmer. $12 \%$ of the region contained varieties in which Jones, 2010 did not characterize a typical regime. 
Table 15. Grapes of the Intermediate Climate Regime of the CGWR. 51\% of the grape varieties planted within the Intermediate climatic zone are typical of an intermediate climatic region, characterized by Jones, $2010.7 \%$ of the grapes are typical of a warm climatic region and $42 \%$ are grapes typical for a cool climatic regime

Table 16. Grapes of the warm-climatic regime of the CGWR. Of the grapes characterized by Jones et al. (2010), only warm varietals are present in the warm climatic regime, compromising $87 \%$ of the total acreage.

Table 17. The equations used in the Statistics calculator to calculate growing degree days in GIS are provided below. To determine GDDs from a monthly dataset, GDD values had to be multiplied by the average days in each month (bold). This resulted in a value that was similar to GDDs each month, but will vary from GDD values calculated from hourly temperature data. 102

Table 18. There are 13 vineyards in which grape variety estimations were not provided. The vineyards labeled "unknown" were sites in which no background information was attained. Expected grape varieties were collected from either online vineyard profiles, winery websites, or communication with owners (Hood River Vineyards \& Winery) 103 


\section{LIST OF FIGURES}

Number

Page

Figure 1. The Columbia Gorge Wine Region (CGWR) is located in both Oregon and Washington, along the Columbia River. It is roughly 45 minutes away from Portland, Oregon and includes the Columbia Gorge American Viticultural Area (AVA) and the southwest portion of the Columbia Valley AVA. 4

Figure 2. Generalized geological map units are compiled from three geological maps for the Hood River Valley (McClaughry et al., 2012b), Oregon (Ma et al., 2009) and Washington State (Staff, 2010) 7

Figure 3. The Columbia River Basalt Group is a large flood lava province that covers more than $167.300 \mathrm{~km} 2$ in the Pacific Northwest and is the dominant basement rock in the CGWR. This figure is modified from Pogue (2009) and was originally based on Tolan et al. (1989). ID- Idaho; MT-Montana; OR-Oregon; WA-Washington. .8

Figure 4. Six major axes of The Yakima Fold Belt extend into the CGWR, forming ridges and valleys near The Dalles, Mosier Valley, Columbia Hills and Bingen anticline. The figure taken from Pogue (2012) and the fold locations were provided by Tolan et al. (1989). The two field trip stops described in Pogue (2012) were located at Syncline Winery and Maryhill Winery. 9

Figure 5. Elevations of Flood Features compiled by Benito and O'Connor (2003) suggest that flood elevations decreased from east to west as it traveled through the Columbia Gorge 12

Figure 6. The extent of loess in the CGWR was determined using the soil surveys. Soils desribed as forming in loess were labeled as yes, where as soils not formed in loess are labeled as no. Loess appears to be a dominant surficial deposit in the CGWR, especially on the eastern boudaries.

Figure 7. Soils representing six soil orders are present wihtin the CGWR. The region is dominated by Mollisols (grassland soils) in the eastern portions 
and Hood River Valley (Soil Survey Staff, 2010). The western CGWR has a mix of soil orders, including Andisols (volcanically derived), Inceptisols (young soils) and Alfisols (well developed and fertile).

Figure 8.Climate maturity groupings are defined for Oregon by Jones et al. (2002) based on the approximate ripening period potential for each grape variety in wine regions worldwide. Figure is taken from Jones et al., (2010).

Figure 9. Aerial Photographs from the National Agriculture Imagery Program (NAIP) were used to trace vineyard boundaries once GPS locations were imported into Arc Map. This example shows Ziegler Brothers Family Vineyard (top left), Columbia River View Vineyard (new planting example) and Underwood Mountain Vineyards (bottom left). 26

Figure 10. The soil vector data taken from the gSSURGO database were joined with a series of attribute tables in order to collect the adamant soil information to define the terroir of the CGWR (Soil Survey Staff, 2012a, b).

Figure 11. 37 wineries are located in the CGWR with one winery (15 Mile Winery) outside of the AVA boundaries, 24 wineries in the Columbia Gorge AVA

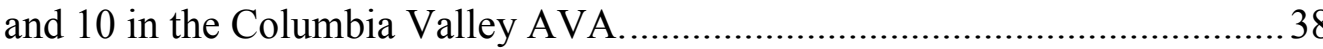

Figure 12. As of 2013, there are 82 vineyards located in the CGWR and one vineyard (Deere Run Family Vineyard) outside the CGWR.

Figure 13. Percentages are based on acreage estimations provided by vintners during the grower's survey. The numbers within each pie chart represent the number of vineyards that have planted each grape variety Pinot Noir is the mostly widely planted grape within the CGWR. Other cool varieties (labeled green, blue or purple) that dominate the CGWR include Chardonnay, Pinot Gris, Riesling and Gewürztraminer. Warm varieties (labeled red, orange or yellow) that dominate in the CGWR include Syrah, Merlot and Zinfandel. In general, the Columbia Gorge (CG) AVA is dominated by early varietal grape varieties (74\%) while for the exception of Pinot Noir, the dominate grape varieties in the Columbia Valley (CV) AVA are warm varietals $(45 \%)$ 
Figure 14. Majority of the vineyards that have dry farming practices (no irrigation during the growing season) are located in the western portions of the study area (orange circles).

Figure 15. The annual precipitation in the CGWR decreases from over 100 centimeters ( $\sim 40$ inches) in the south-western boundaries, to less than 30 centimeters $(<10.8$ inches) in the eastern portions near the Columbia River and Deschutes River

Figure 16. The average growing season precipitation calculated using 1981-2010 PRISM data was less than 4.0 centimeters (1.6 inches) between 1981 and 2010. For the exception of one vineyard, dry-farming irrigation is practiced among vineyards receiving on average greater than 2.0 centimeters of precipitation during the growing season.

Figure 17. The climate groupings defined by average growing season temperatures (GSTs) range from cool to warm. Area too cool for viticulture are located outside the CGWR, and at the highest elevation in the Columbia Hills. Majority of the vineyards in the CGWR are located within an intermediate climate. The GST Measurements for each climatic grouping above have been adjusted to reflect GST values measured at each vineyard and are not the identical to the measurement groupings provided by Jones et al., (2010). . 49

Figure 18. Vineyards in highest in elevation and in the coolest regimes tend to be in the western portions of the CGWR, while those on the eastern side tend to be lower in elevation and contain a warmer climate. Note that elevation is not directly related to each climatic regime, as vineyards in similar elevation on Underwood Mountain and in Mosier are characterized in different regimes. The climatic boundaries in the CGWR are dependent on both elevation and east and west locations.

Figure 19. Growing degree-days range from 1396 to 3004 in the CGWR, based on ${ }^{\circ} \mathrm{F}$. Vineyards are located within three Winkler Regions from criteria set by Winkler and Amerine (1994) and updated by Jones (2003). Most vineyards are within Region $\mathrm{Ib}$ (51\%). The GDD Measurements for each Winkler 
Region above have been adjusted to reflect GDD values measured at each vineyard and are not the identical to the measurement groupings provided by Jones et al., (2010). For example, 3004 GDD s was the highest GDD value measured among the vineyard sites, however Region III as defined by Jones et al., (2010) includes GDD values ranging from $3000-3500$.

Figure 20. Seven soil regions were drawn based on the clustering of 20 common soil series in the CGWR. The soil sub regions were named by the geographic location within each boundary. These 20 soil series account for $98.7 \%$ of the total growing acreage

Figure 21. There are 18 vineyards located within the Hood River soil sub-region. Five soil pits were dug in this sub-region: at Phelps Creek Vineyard, Blue Chip Vineyard, Wy'East Vineyard and Marchesi Vineyard to further analyze the common soil series in this sub-region.

Figure 22. There are 19 vineyards within the Underwood Mountain soil sub-region. Vineyards in this sub-region are dominated by Quaternary volcanic deposits, the Chemawa and Underwood soil series. Soil pits in this sub-region were both located at Underwood Mountain Vineyards

Figure 23. There are 5 vineyards within the Mosier soil sub-region. Due to times constraints, the soil was not further examined among soil pits. Majority of the vineyards in this sub-region are planted on Missoula Flood deposits and loess. This soil sub-region was drawn to include vineyard primarily planted on the Wind River and Wamic soil series

Figure 24. There are ten vineyards located within the Lyle soil sub-region. Two soil pits were dug at Parkers (Memaloose) Vineyard and Cor Cellars Vineyard....73

Figure 25. There are 7 vineyards ( 77 acres) near Dallesport, Washington that are dominated by the Fisherhill, Ewall, and Dallesport Series. The geological deposits vary from Loess at higher elevation vineyards, to Missoula Flood and Sand Dune deposits at lower elevation vineyards. The soil pits were dug at three vineyards in the Dallesport soil sub-region. 
Figure 26. There are 13 vineyards within The Dalles soil sub-region. Vineyards in this region overly the Cherryhill and Chenoweth Series, as well as the Missoula Flood and loess deposits. One soil pit was analyzed at Hi Valley Vineyard and another soil pit was analyzed at HD LLC (Hillside) Vineyards.

Figure 27. There are five vineyards (totaling to 189 hectares; 513 acres) within the Maryhill sub-region. Vineyards in this region are dominated by Loess, the Walla Walla series and the Quincy Series. Sites close to the Columbia River contain skeletal and sandy textures and derived from alluvium and Missoula Flood deposits. Silt loam textures are common of sites derived in loess.

Figure 28. The extent of the Missoula Floods is estimated using maximum flood elevation provided by Benito and O'Connor (2003).All soil pits containing a skeletal texture are below evidence for maximum flood elevations. Soil pit identifications are as the following: 1-Marchesi \#1, 2-Marchesi \#2, 3Phelps Creek, 4-Wy'East, 5-Blue Chip, 6-Underwood Mt. \#1, 7-Underwood Mt. \#2, 8- Cor Cellars, 9-Parkers (Memaloose), 10-Graves, 11-Bethany in the Gorge, 12-Chuckar Ridge, 13-Sunshine Mt, 14-HD LLC, 15-Dry Hollow.

Figure 29. Soil texture and development characterized at each soil pit varies above and below the expected Missoula Flood elevations. All the sites containing skeletal textures are below expected Missoula Flood elevations. Above the expected Missoula Flood elevations, geological deposits influencing the soil include lahars, loess, The Dalles Formation and Basalt.

Figure 30.Climate maturity groupings based upon average growing season temperatures (Jones et al., 2002b). The vertical dark blue bar is the mean value for the CGWR, while the shaded area is the predominant climate suitability in the region (+/- 1.0 standard deviation about the mean). 92 


\section{CHAPTER 1: INTRODUCTION}

Along with the skill of a winemaker and vineyard management techniques, the natural environment influences the production and character of wine (Burns, 2012).

Terroir is a term used by French winemakers that refers to the complex interaction of the physical aspects at a vineyard site, which combine to create a particular "taste of the place" for where the grapes are grown (Unwin, 2012). The physical aspects commonly recognized as combining to create a unique expression in a wine include the grapes themselves, soil, underlying geology, topography and climate. In Europe, both viticulture and winemaking techniques have evolved in response to the unique physical terroir of each region (Pogue, 2009). Hundreds of years of trial and error have also allowed wine grapes to be matched with terroirs that encourage the best expression of that variety, such as Pinot Noir in Burgundy and Riesling in the Mosel Valley (Pogue, 2012). Terroir research in new world wine regions, such as the United States, has been motivated by discussions with winemakers who aim at shortening the trial and error process (Meinert and Busacca, 2000, 2002).

Recent terroir research conducted in the in the Pacific Northwest has been conducted using a combination of field work and existing earth science databases on soils, geology, topography and climate to define the terroir on a regional scale (Burns, 2012; Jones et al., 2004; Meinert and Busacca, 2000, 2002). Terroir conditions have been defined for the Willamette Valley (Burns, 2012), Walla Walla Valley (Meinert and Busacca, 2000; Pogue, 2012), Umpqua Valley (Jones et al., 2004), and the Red Mountain AVA in Washington (Meinert and Busacca, 2002). The purpose of this thesis is to focus 
on the variations in vineyard geology, soil, topography and climate that have produced a broad range of physical terroirs within the Columbia River Gorge Wine Region, a region in which the terroir has yet to be defined.

The Columbia Gorge Wine Region (CGWR) is located along a roughly east-west reach of the Columbia River and such includes parts in both Washington State and Oregon State. The region consists of two American Viticultural Areas (AVA)'s: the Columbia Gorge AVA and the southwest portions of the Columbia Valley AVA (Figure 1). The CGWR is emerging as a wine region, increasing from about 43 vineyards to 82 vineyards in the past decade alone. This region has already gained recognition as a "World of Wine in 40 miles" by the diverse range of grape varieties planted within this relatively small region (over 30 varietals) (Columbia Gorge Wine Association, 2012). This is attributed to the differences in climatic conditions within the CGWR. As the CGWR continues to grow, vintners and winemakers continue to experiment with different types of grape varieties, to determine the best quality of wine for this region. Although the climate is well known by vintners to vary within the region, definitive boundaries of the climatic conditions have not yet been defined. Also, little is known about how other terroir conditions, such as the geology, soils, and topography vary at vineyard sites throughout the region.

It is important for a winemaker to have a strong background in winemaking, knowledge of the terroir conditions and how to adjust winemaking and vineyard management techniques to the terroir conditions in order to make a preferable wine 
(Unwin, 2012). Therefore, the dominant physical terroir conditions at each vineyard block within the CGWR are compiled and formatted into a GIS database for vintners to 


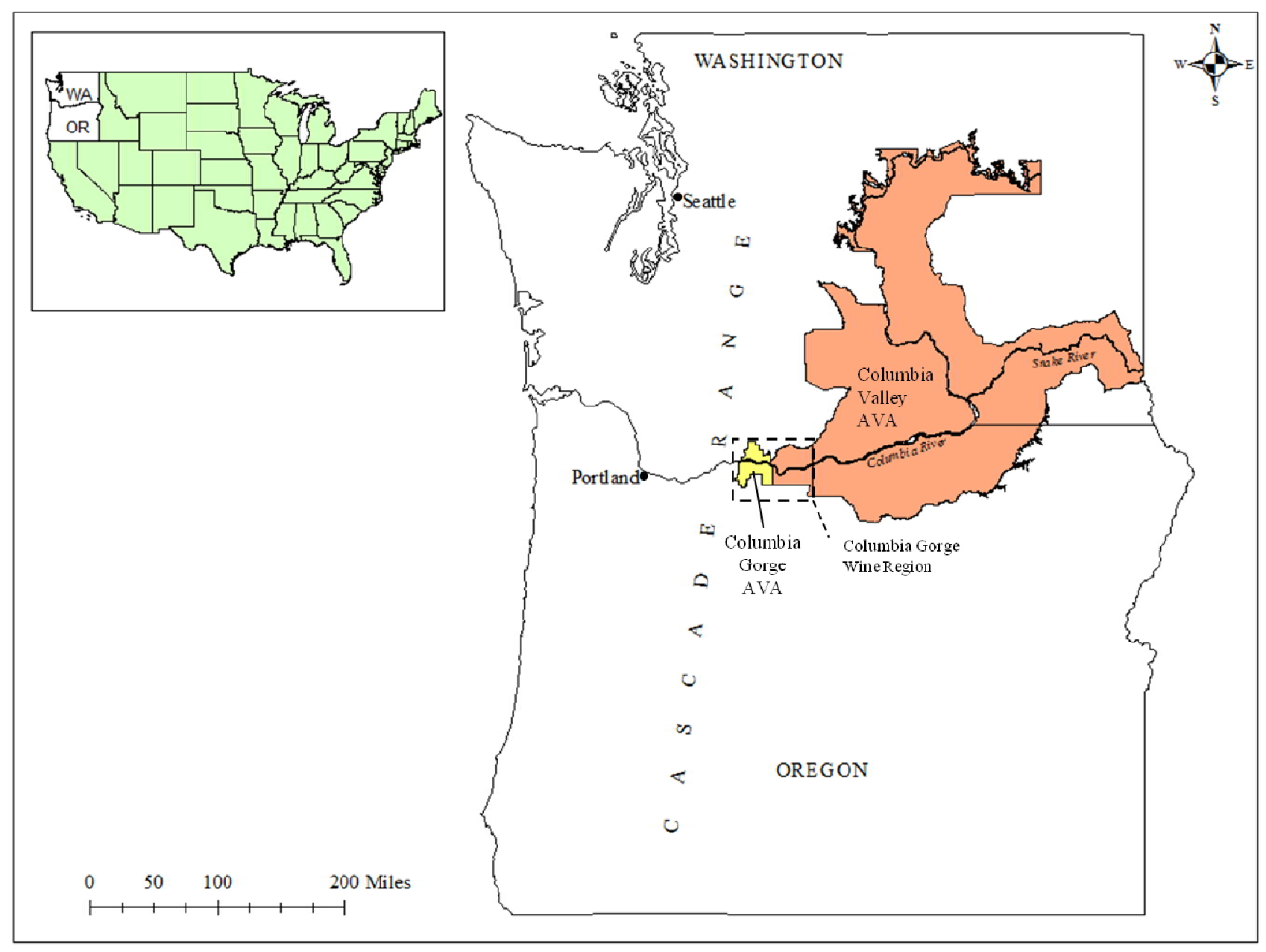

Figure 1. The Columbia Gorge Wine Region (CGWR) is located in both Oregon and Washington, along the Columbia River. It is roughly 45 minutes away from Portland, Oregon and includes the Columbia Gorge American Viticultural Area (AVA) and the southwest portion of the Columbia Valley AVA. 
use as a general guideline to the terroir conditions at each site. The goal of this research is to provide winemakers in this region with the knowledge of major terroir conditions in order to bolster the quality of wine made from this area. Defining the terroir of the CGWR will also provide a better understanding of the physical environment that affects wine quality in Washington and Oregon.

\subsection{Objectives:}

- Determine the locations of existing wineries and vineyards inside the Columbia Gorge Wine Region;

- Extract topographical, geological, climatic and soil information for each vineyard site in a Geographic Information System (GIS) using existing earth science databases; and

- Compare commonalities and differences in the terroir conditions at vineyard sites to determine dominant physical factors that unite a unique collection of terroirs in the Columbia Gorge. 


\section{CHAPTER 2: BACKGROUND AND PREVIOUS WORK}

\subsection{Geologic Setting in the CGWR}

Miocene-aged basalt of the Columbia River Basalt Group (CRBG) (Mb; Figure 2; Figure 3) is the oldest known rock-unit exposed in the CGWR (Ma et al., 2009; McClaughry et al., 2012a; Washington Department of Natural Resources Staff, 2010). The CRBG is composed of a succession of tholeiitic basalt and basaltic andesite lava flows that cover more than $167,300 \mathrm{~km}^{3}$ of land in the Pacific Northwest (Tolan et al., 1989). These lava flows erupted from north-northwest-trending fissures on the border of Oregon, Washington and Idaho between 17 to $6 \mathrm{Ma}$ (Tolan et al., 1989). It is estimated that at least 28 separate flows extend into the CGWR, forming rock layers up to 610 meters (2000 feet) thick (Norman and Busacca, 2004; Reidel et al., 1989; Tolan et al., 1989).

During the emplacement of the CRBG (ca. $16 \mathrm{Ma}$ ) compressional stresses began to take place in south-central Washington from the rotation of the Pacific Plate (Reidel et al., 1994; Reidel et al., 1989). These compressional stresses formed a series of east-west trending ridges and basins that extend from central Washington to the CGWR, referred to as the Yakima Fold Belt (Reidel et al., 1989). Axes of the Yakima Fold Belt restricted younger CRBG flows to the eastern portions of the Columbia River Gorge and Columbia Valley (McClaughry et al., 2012a). Compressional deformation from the Yakima fold belt continued in the CGWR through the Pliocene, shown by the folding of 3 Ma lava flows along the Bingen anticline (McClaughry et al., 2012a). Volcaniclastic and sedimentary deposits overly the CRBG in synclinal basins of the CGWR 


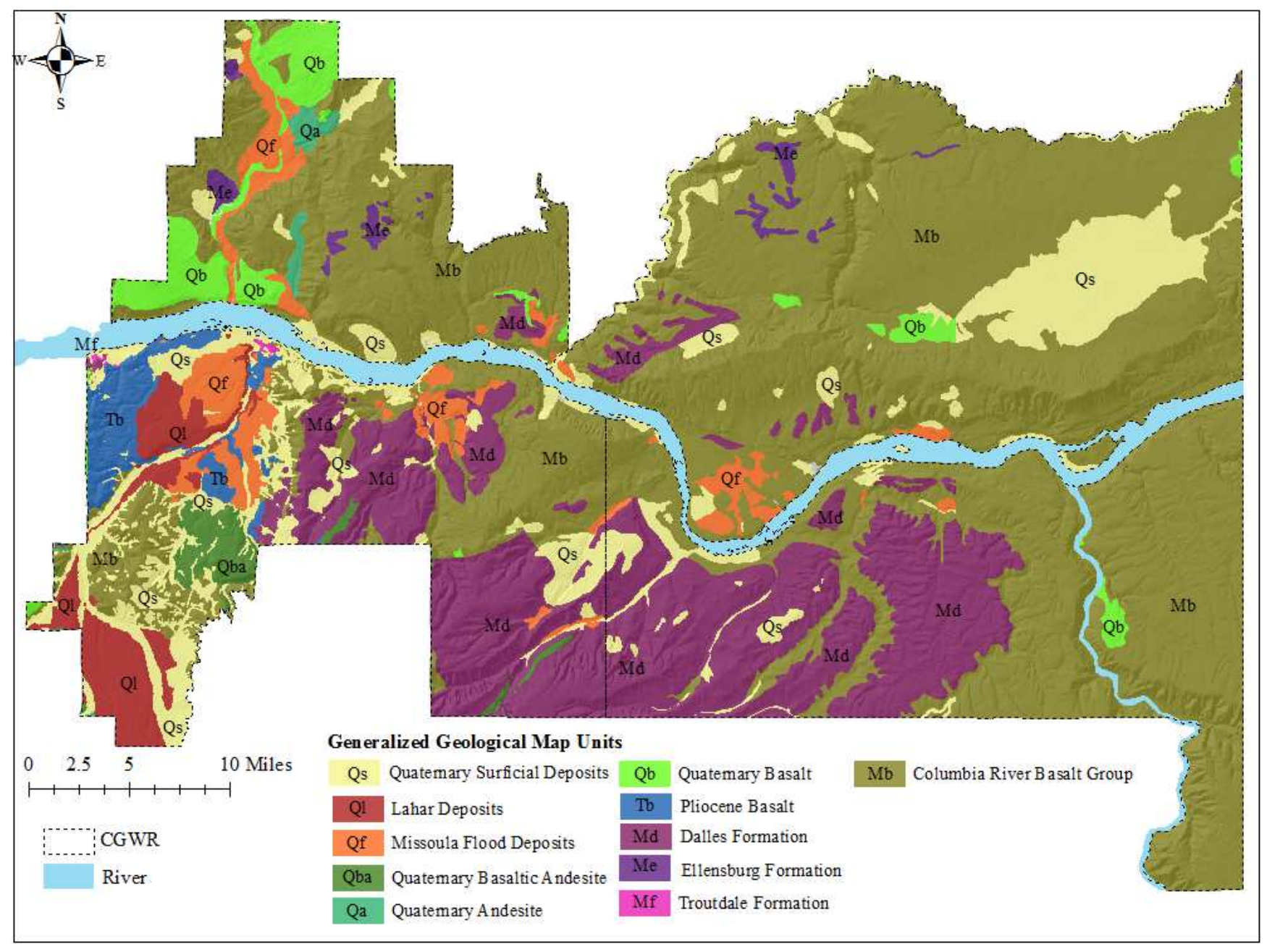

Figure 2. Generalized geological map units are compiled from three geological maps for the Hood River Valley (McClaughry et al., 2012b), Oregon (Ma et al., 2009) and Washington State (Staff, 2010). 


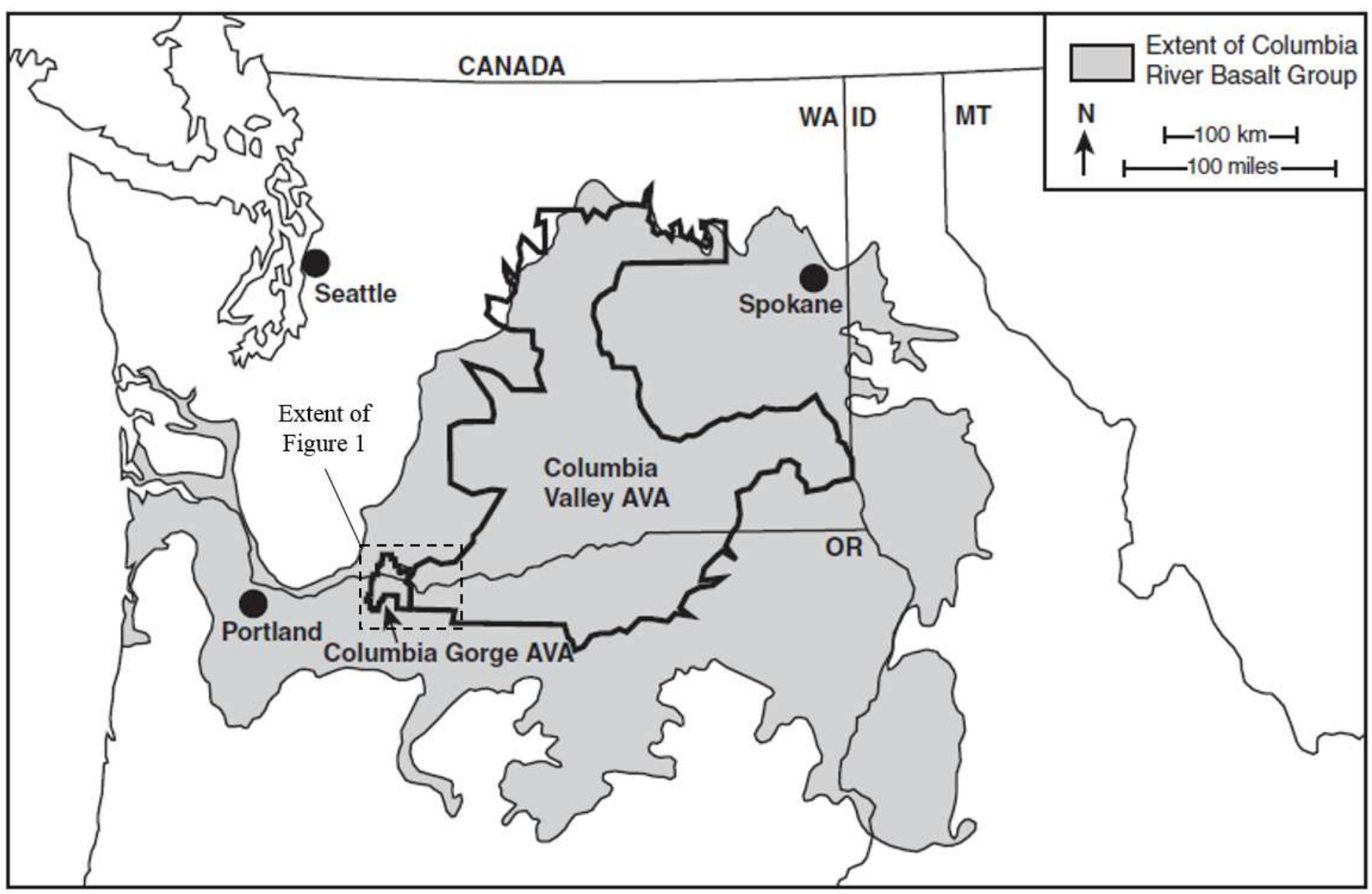

Figure 3. The Columbia River Basalt Group is a large flood lava province that covers more than $167.300 \mathrm{~km} 2$ in the Pacific Northwest and is the dominant basement rock in the CGWR. This figure is modified from Pogue (2009) and was originally based on Tolan et al. (1989). ID- Idaho; MT-Montana; OR-Oregon; WA-Washington. 


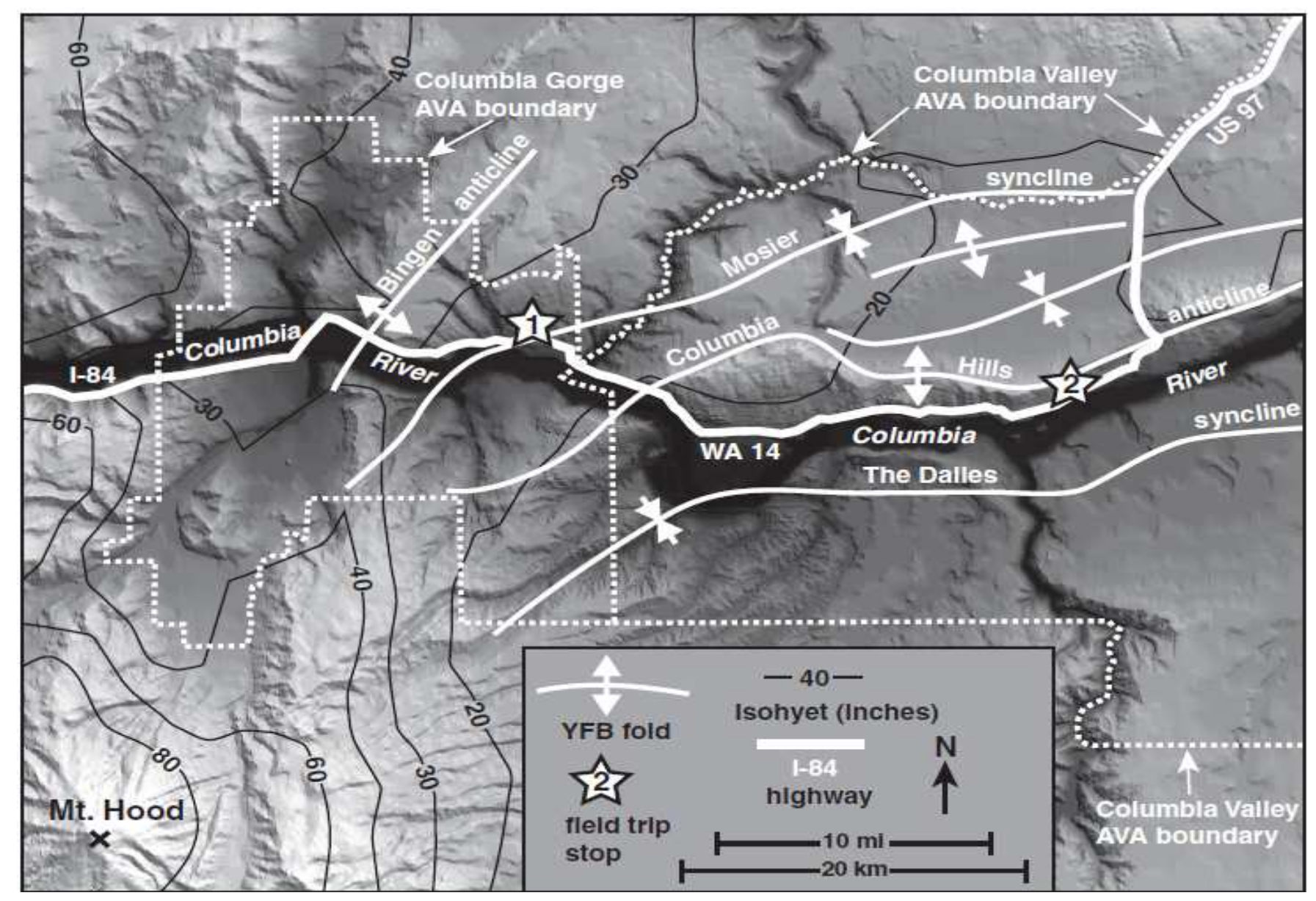

Figure 4. Six major axes of The Yakima Fold Belt extend into the CGWR, forming ridges and valleys near The Dalles, Mosier Valley, Columbia Hills and Bingen anticline. The figure taken from Pogue (2012) and the fold locations were provided by Tolan et al. (1989). The two field trip stops described in Pogue (2012) were located at Syncline Winery and Maryhill Winery. 
(McClaughry et al., 2012a; Pogue, 2009). Volcaniclastic and sedimentary deposits eroded from Mount Hood that are deposited near The Dalles, Mosier and Lyle are referred to as The Dalles Formation (Ma et al., 2009; McClaughry et al., 2012a) whereas ancestral Columbia River fluvial deposits in the Hood River Valley and eastward towards Portland, Oregon are referred to as The Troutdale Formation (McClaughry et al., 2012a). Few extents of The Troutdale Formation are mapped in the CGWR at locations close to current Columbia River in the Hood River Valley (McClaughry et al., 2012a).

Other bedrock commonly found within the CGWR includes locally derived Quaternary volcanic deposits, such as the basalt flows on Underwood Mountain and several basaltic andesite and andesite lava flows from vents on Booth Hill and Van Horn Butte in the Hood River Valley (McClaughry et al., 2012a). Two Quaternary lahar deposits are also located within the Hood River Valley, known as the Hood River and Oak Grove Lahars (McClaughry et al., 2012a). It is inferred that the Hood River lahar originated as a debris avalanche from the north flanks of Mount Hood (McClaughry et al., 2012a). The source for the Oak Grove lahar is unknown but is assumed to have traveled from Mount Hood as well (McClaughry et al., 2012a).

Between 18,000 and 15,000 calendar years ago, cataclysmic floods were released repeatedly from an ice dam blocking glacial Lake Missoula on the Idaho-Montana border (Allen et al., 2009). At least 40 floods swept across large parts of the Columbia Basin eroding the existing soils and landscape (Waitt, 1985). When the flood waters traveled through the Columbia Gorge, constrictions such as Mitchell Point and Rowena Gap 
slowed velocities on the upstream, forming temporary ponds and lakes (Benito and O'Connor, 2003).

There are two types of Missoula Flood deposits in the Gorge: (1) high energy deposits of unsorted gravels, sands and silts and (2) slack water deposits in the side canyons (rhythmites), which contain graded beds of sand with silts on top. Gravel, sand and silt deposits formed by the Missoula Floods are mapped within the CGWR at low elevations close to the Columbia River and in surrounding tributaries (Ma et al., 2009; McClaughry et al., 2012a; Washington Department of Natural Resources Staff, 2010). The highest elevations of ice-rafted erratics, flood deposits and erosional features formed by the Missoula Floods within the Columbia Gorge are compiled by Benito and O'Connor (2003). These features represent the maximum known flood elevations in the CGWR (Benito and O'Connor, 2003). Flood feature elevations decrease from 323 meters (1060 feet) west of Maryhill, Washington to 283 meters (928 feet) west of Mosier, Washington (Benito and O'Connor, 2003).

Miocene and Quaternary bedrock is draped by numerous Quaternary $(<2,6 \mathrm{Ma}$ in age) surficial deposits, including landslides, alluvium, debris fans and older terrace deposits (Ma et al., 2009; McClaughry et al., 2012a; Washington Department of Natural Resources Staff, 2010). Soils that have formed in Quaternary loess (windblown silt) are very common in the CGWR, suggesting that loess is a dominant surficial deposit in the eastern boundaries and higher elevations of the CGWR (Ma et al., 2009; McClaughry et al., 2012a; Soil Survey Staff, 2012a, b; Washington Department of Natural Resources Staff, 2010). Also, one vineyard is found on an ancient sand dune in Dallesport. 


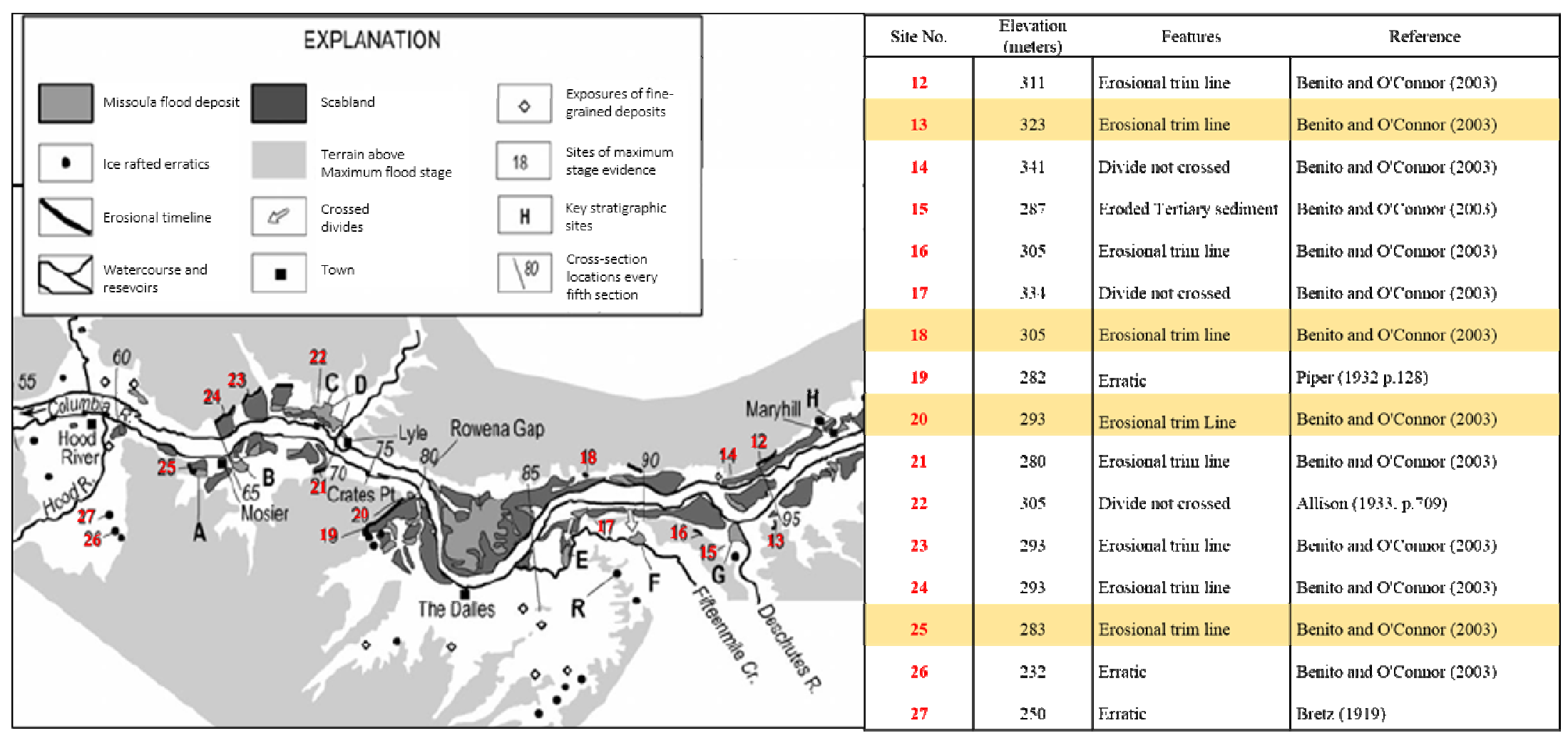

Figure 5. Elevations of Flood Features compiled by Benito and O'Connor (2003) suggest that flood elevations decreased from east to west as it traveled through the Columbia Gorge. 


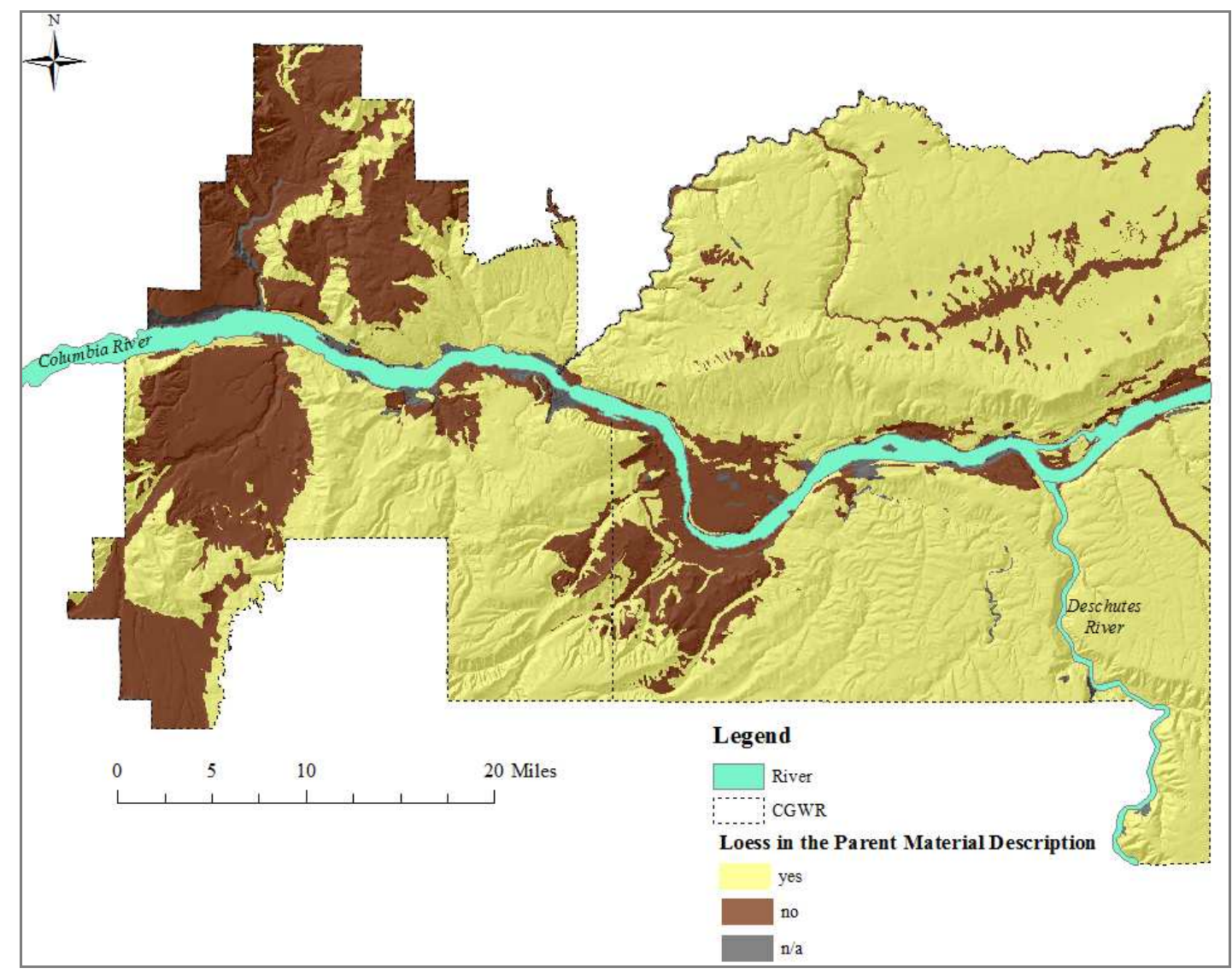

Figure 6. The extent of loess in the CGWR was determined using the soil surveys. Soils desribed as forming in loess were labeled as yes, where as soils not formed in loess are labeled as no. Loess appears to be a dominant surficial deposit in the CGWR, especially on the eastern boudaries. . 


\subsection{Soils of the CGWR}

Soils weathered from volcanic deposits (Andisols) are common in the western agricultural regions of Hood River and Underwood Mountain, where young basalt flows and lahar deposits are present (Soil Survey Staff, 2010, 2012a, b). Very dark colored, grassland soils (Mollisols) are common throughout the entire region and dominate agricultural regions near The Dalles, eastward towards Maryhill and the valley bottoms near Hood River and Mosier (Figure 7). Soils slightly younger in age and lighter in color (Inceptisols) are common near Mosier, Hood River and Underwood Mountain. Very young soils containing no soil profile development that are associated with shifting sand dunes (Entisols) are located near the Columbia River and within surrounding tributaries (Soil Survey Staff, 2010, 2012a, b). Alfisols are naturally fertile soils that have a higher base saturation $(>55 \%)$ and clay content relative to other soils found in the region because they are older. Dry soils common in desert environments (Aridisols) are present on the southeastern portion close to the Deschutes River (Figure 7). Majority of the soils present in the CGWR are loam-rich and contain a xeric moisture regime.

\subsection{Climate Setting}

The CGWR is located in a transitional climatic zone between the wet, marineinduced climate of the Cascade Range and the dry continental climate of eastern Oregon and Washington (McClaughry et al., 2012). Orographic precipitation effects from the Cascade Range cause rainfall to rapidly decline within the region, reducing from 76 centimeters (30 inches) in Hood River, Oregon, to roughly 48 centimeters (19 inches) at Mosier, Oregon and 36 centimeters (14 inches) at The Dalles, Oregon 


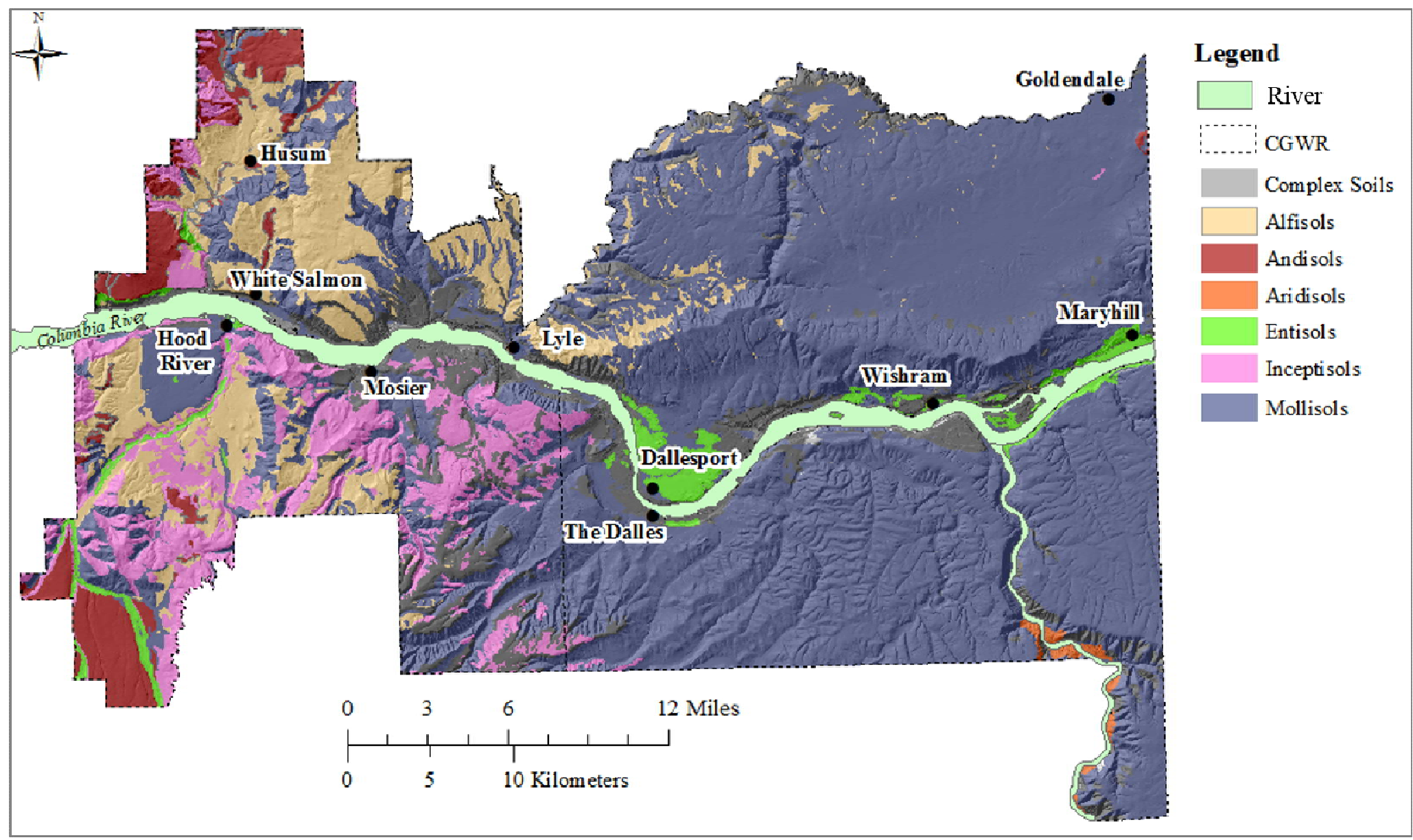

Figure 7. Soils representing six soil orders are present wihtin the CGWR. The region is dominated by Mollisols (grassland soils) in the eastern portions and Hood River Valley (Soil Survey Staff, 2010). The western CGWR has a mix of soil orders, including Andisols (volcanically derived), Inceptisols (young soils) and Alfisols (well developed and fertile). 
(Oregon Climate Service, 2014). The rapid change in precipitation is visibly apparent by the change in native vegetation while driving eastward on Interstate- 84 .

Climate based aspects of terroir are related to many factors at various scales, however regional suitability of vineyards is most often analyzed by the assessment of temperature, also referred to as heat accumulation (Jones et al., 2010). Grapes need certain amount of heat in order to fully develop to accumulate enough sugars for wine development. Therefore, various formulations for growing degree-days (GDD) have been established to attempt to quantify the amount of heat available for vine development during the growing season using daily air temperature measurements (Jones et al., 2010) The most common formulation for growing degree days is the accumulation of degrees above a base temperature of $10^{\circ} \mathrm{C}\left(50^{\circ} \mathrm{F}\right)$ between April 1st to October 31 st (Table 1.). A base temperature of $10^{\circ} \mathrm{C}$ is commonly used because it is the minimum temperature for plant growth (Jones et al., 2010).

GDD values has been used to place broad bounds (or classes) on viticultural suitability in a wine region, with the most common systems being the designation of Winkler regions developed for California (Amerine and Winkler, 1944). A lower and upper class limit and a division of the lower class into Region Ia and Ib was added to the standard Winkler Index to better depict region most suitable for viticulture in the western United States (Jones et al., 2010). The lower class (Region I) was also separated into two indices, one most suitable for the earliest cool climate varieties (Region Ia) and one that is typical for V.Vinifera cool climate varieties (Region Ib) (Jones et al., 2010). The Winkler region growing degree-day limits (Amerine and Winkler, 1944), updated by 
Table 1. The following equations can be used to calculate average growing season temperatures (GST)'s and growing degree day measurements (GDD). These equations are further used in this study to separate the CGWR into climate groupings.

\begin{tabular}{|c|c|c|c|c|c|}
\hline \multirow{2}{*}{ Variable } & \multirow{2}{*}{ Equation } & \multirow{2}{*}{ Months } & \multicolumn{3}{|c|}{ Class Limits } \\
\hline & & & Grouping & ${ }^{\circ} \mathrm{C}$ units & ${ }^{\circ} \mathrm{F}$ units \\
\hline \multirow{7}{*}{$\begin{array}{l}\text { Average Growing Season } \\
\text { Temperature (GST) }\end{array}$} & \multirow{7}{*}{ 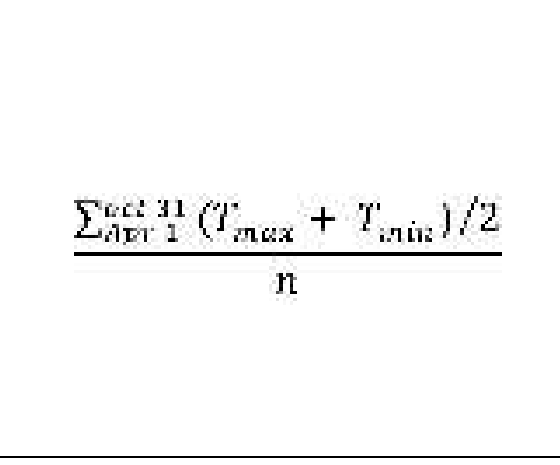 } & \multirow{7}{*}{ Apr-Oct } & Too Cool & $<13^{\circ} \mathrm{C}$ & $<55^{\circ} \mathrm{F}$ \\
\hline & & & Cool & $13-15^{\circ} \mathrm{C}$ & $55-60^{\circ} \mathrm{F}$ \\
\hline & & & Intermediate & $15-17^{\circ} \mathrm{C}$ & $60-63^{\circ} \mathrm{F}$ \\
\hline & & & Warm & $17-19^{\circ} \mathrm{C}$ & $63-66^{\circ} \mathrm{F}$ \\
\hline & & & Hot & $19-21^{\circ} \mathrm{C}$ & $66-72^{\circ} \mathrm{F}$ \\
\hline & & & Very Hot & $21-24^{\circ} \mathrm{C}$ & $72-75^{\circ} \mathrm{F}$ \\
\hline & & & Too Hot & $>24^{\circ} \mathrm{C}$ & $>75^{\circ} \mathrm{F}$ \\
\hline \multirow{8}{*}{ Growing degree-days (GDD) } & \multirow{8}{*}{ 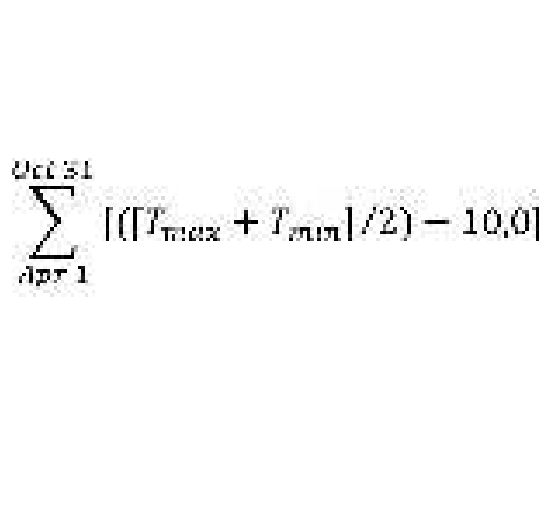 } & \multirow{8}{*}{ Apr-Oct } & Too Cool & $<850$ & $<1500$ \\
\hline & & & (Region Ia) & \multirow{2}{*}{$850-1389$} & $1500-2000$ \\
\hline & & & (Region Ib) & & $2000-2500$ \\
\hline & & & (Region II) & $1389-1667$ & $2500-3000$ \\
\hline & & & (Region III) & $1667-1944$ & $3000-3500$ \\
\hline & & & (Region IV) & $1944-2222$ & $3500-4000$ \\
\hline & & & (Region V) & $2222-2700$ & $4000-4900$ \\
\hline & & & Too Hot & $>2700$ & $>4900$ \\
\hline
\end{tabular}


Table 2. Growing degree-days have been correlated with suitable grape varieties by Jones et al. (2010). Wine regions have also been compared by Jones et al. (2010) using growing degree days. Some of the more popular and regional relevant wine regions are included below.

\begin{tabular}{|c|c|c|c|}
\hline Region & $\begin{array}{l}\text { Degree-Days } \\
\text { (F units) }\end{array}$ & Suitability & Other Wine Region \\
\hline Region Ia & $1500-2000$ & $\begin{array}{l}\text { Only very early ripening varieties } \\
\text { achieve high quality, mostly hybrid } \\
\text { varieties and some V. Vinifera }\end{array}$ & \multirow{2}{*}{$\begin{array}{c}\text { Champagne, France, Burgundy, France \& } \\
\text { Willamette Valley, Oregon }\end{array}$} \\
\hline Region Ib & $2000-2500$ & $\begin{array}{c}\text { Only early ripening varieties achieve } \\
\text { high quality, mostly hybrid varieties and } \\
\text { some V. Vinifera }\end{array}$ & \\
\hline Region II & $2500-3000$ & $\begin{array}{c}\text { Early and mid-season table wine } \\
\text { varieties will produce quality wines }\end{array}$ & Bodeaux, France \& The Umpqua Valley, Oregon \\
\hline Region III & $3000-3500$ & $\begin{array}{c}\text { Favorable for high production of } \\
\text { standard to good quality table wines }\end{array}$ & Mendocino, Sonoma \\
\hline Region IV & $3500-4000$ & $\begin{array}{l}\text { Favorable for high production, but } \\
\text { acceptable table wine quality at best }\end{array}$ & Napa Valley, Chianti \\
\hline Region V & $4000-4900$ & $\begin{array}{l}\text { Typically only suitable for extremely } \\
\text { high production, fair quality table wine } \\
\text { or table grape varieties destined for } \\
\text { early season consumption or growth. }\end{array}$ & Fresno, Bakersfield \\
\hline
\end{tabular}


Jones et al. (2010), is a better depiction of cool climate limits for viticulture and can be used to determine the boundaries between micro-climates in the CGWR (Jones et al.,2010). Each of the five classes represent a unique set of growing conditions (Jones, 2011)

In addition to the Winkler Index, average growing season temperatures (GST)'s can be used to define separate climatic boundaries within the CGWR. GSTs are calculated using average monthly growing season temperatures, and the resulting value is classed into five different climate maturing groupings suitable for viticulture: cool intermediate, warm, hot and very hot (Jones et al., 2010). The climate maturity groupings have also been used by Jones et al. (2002) to correlate climate and grape maturity potentials for different grape varieties grown in the wine regions around the world (Jones et al., 2002).

Similar to changes in precipitation, air temperatures vary from west to east in the CGWR. Two weather stations provided by the AgWeatherNet website administered by Washington State University, are installed close to vineyards at the eastern and western CGWR boundaries (Washington State University Staff, 1988). These stations provide a comparison of annual air temperature, annual precipitation, and GDD extremes from east to west over the past five years (Appendix A - 1; Appendix A - 2; Appendix A - 3). The precipitation at the eastern most vineyard site on Underwood Mountain has been between 24 to 43 more inches compared to the site by Maryhill, Washington (Appendix A - 1). On average, the annual temperatures measured at the Maryhill Station are $15^{\circ} \mathrm{C}\left(4^{\circ} \mathrm{F}\right)$ higher than what is measured at the Underwood site (Appendix A - 2). Growing degree-days, are 


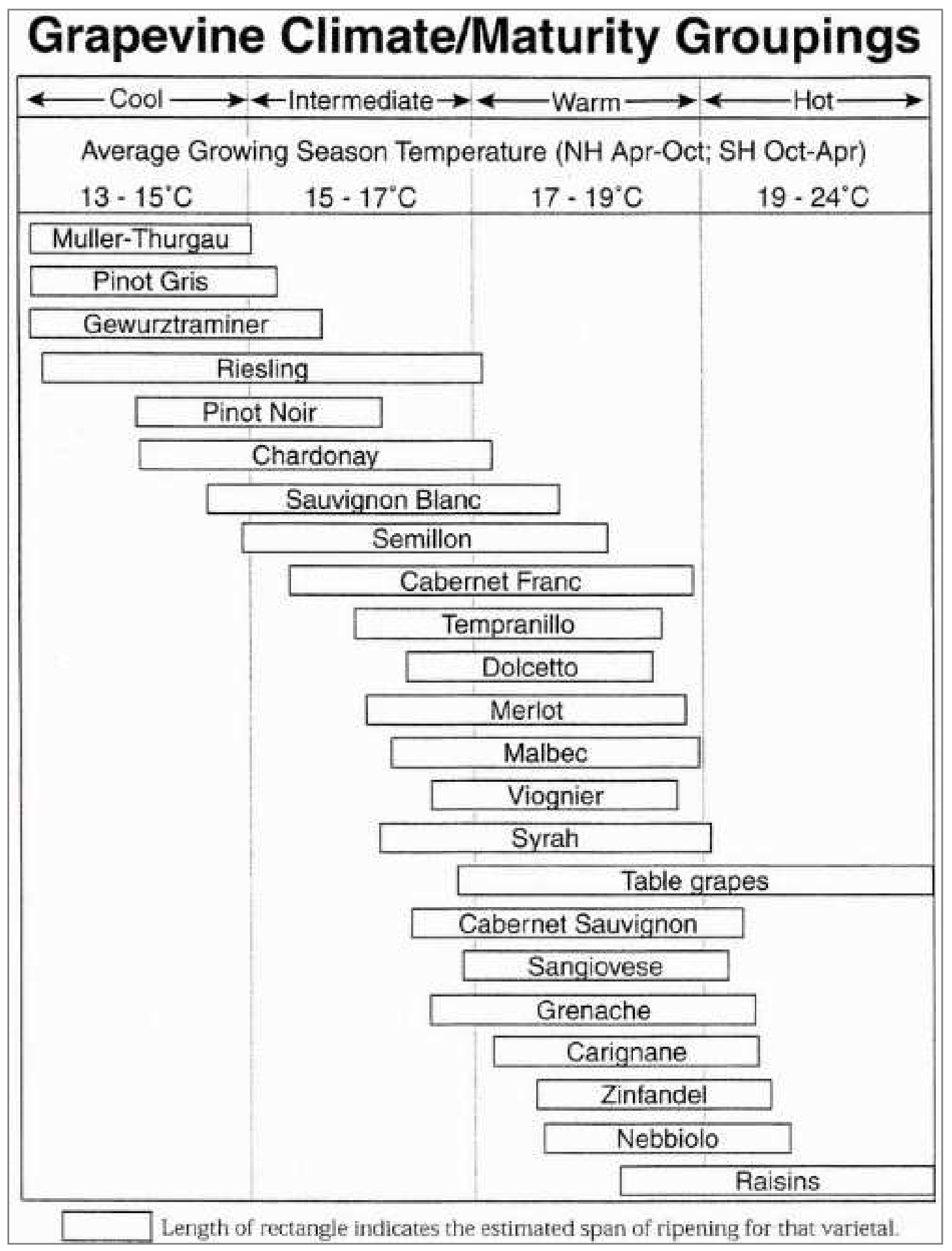

Figure 8.Climate maturity groupings are defined for Oregon by Jones et al. (2002) based on the approximate ripening period potential for each grape variety in wine regions worldwide. Figure is taken from Jones et al., (2010). 
also consistently higher at the Maryhill site, with at least 150 more growing degree days recorded in Maryhill the past five years (Appendix A - 3 Although extremes) in.temperature and precipitation are apparent from the AgWeatherNet Station data, the boundaries of the differences in climatic boundaries have not yet been compiled.

Jones et al.(2010) spatially modeled the GST and GDD for wine regions in the western United States, including the Columbia Gorge AVA and the Columbia Valley AVA, using PRISM (Parameter-elevation Relationships on Independent Slope Model) data from 1971-2000 (Jones et al., 2010). PRISM is the official spatial climate dataset of the USDA and reflects the current state of knowledge of spatial climate patterns in the United States (Daly et al., 2008). GDDs calculated within the Columbia Gorge AVA ranged from 686 to 1490 (units in ${ }^{\circ} \mathrm{C}$ ) (Jones et al., 2010). GST values ranges from 12.6 to $16.9^{\circ} \mathrm{C}$, representing cool to intermediate climatic groupings (Jones et al., 2010). The boundaries of the GST and GDD groupings were not established in this study and have not been updated with more current datasets. Therefore, this study attempts to use the methods set by Jones to depict separate climatic regimes within the Columbia Gorge Wine Region using updated 1981-2010 PRISM climatic normals.

\subsection{History of vineyards and winemaking in the CGWR}

Grape growing in the CGWR extends back to the 1880's when American vines brought from Illinois were planted on a south-facing slope above Bingen, Washington by the Jewett family, founders of White Salmon, Washington (Bugenhagen, 2008). Two other families that introduced grape cuttings to the CGWR include John Balfour, who raised grapes near Lyle, Washington in the late 1900's and Leonis and Elizah Meress, 
who brought vine cuttings with them from their native village in one of France's coldest regions (Bugenhagen, 2008). Some of the oldest Zinfandel grapes in the state of Oregon were planted near the Dalles, Oregon in the late 1800's by Louie Comini, an Italian immigrant stone mason (Lonnie Wright, The Pines 1852 Vineyard, verbal communication,, 2013). This century-old vineyard, now named the Pines 1852 vineyard and managed by Lonnie Wright, is one of the oldest vineyards in the region to be currently in production.

Many of the older vineyards planted in the CGWR emerged from experimental plots planted in the 1960's and 1970's. Charles (Chuck) Henderson planted a Gewürztraminer vineyard near White Salmon, Washington in 1965 under the guidance of Dr. Walter J. Clore, a pioneer in grape growing and agricultural research in Washington State (verbal commun., Steven Thompson and Rick Ensminger, 2013). Similar in time, Don Graves also received advice from Dr. Clore to experiment with 24 grape varieties near Dallesport, Washington (Larsen, 2014). Don Graves' vineyard was expanded to a 16-acre site vineyard in the early 1960's, containing varieties such as Cabernet Sauvignon, Chenin Blanc, Grenache, and Riesling (Larsen, 2014). Test blocks planted on Underwood Mountain in 1973 by Dr. William McAndrew originally contained seven different grape varieties (verbal communication, Rick and Jody Ensminger, 2013). Experimentation eventually led to the planting of Chardonnay, Pinot Gris and Gewürztraminer, all which are now known to do well on Underwood Mountain (verbal communication, Rick and Jody Ensminger, 2013).

The American Viticulture Areas system was established in 1978 to regulate the 
proper use of geographic areas of origins on wine labels by designating boundaries to wine regions that have unique terroir condition (Bugenhagen, 2008). In 1984, the petition for the Columbia Valley AVA was approved, and the boundaries encompass areas with viticultural potential within the Columbia Basin and Columbia River Gorge principally regions at low elevations with an arid to semi-arid climate (Pogue, 2009). The Columbia Gorge AVA was established twenty years later in 2004, designating an area that encompassed silt loam soils, elevations below 610 meters (2,000 feet), annual rainfall between 50.8 centimeters to 102 centimeters ( 20 inches to 40 inches), and average growing season temperatures between $16^{\circ} \mathrm{C}$ and $18^{\circ} \mathrm{C}\left(61^{\circ} \mathrm{F}\right.$ and $\left.65^{\circ} \mathrm{F}\right)($ Columbia Gorge Wine Association, 2002).

The petition for the Columbia Gorge AVA was submitted in 2002 and included 4 wineries and 24 vineyards, totaling to 284 acres (Columbia Gorge Wine Association, 2002). The 24 vineyards were grown on 7 different soil series, including the: Chemawa, Underwood, McElroy, McGowan, Oak Grove, Parkdale, Van Horn, Wyeast and Wamic Series. These vineyards were dominated by early ripening varietals, such as Pinot Noir, Chardonnay, and Gewürztraminers (Columbia Gorge Wine Association, 2002). According to the Columbia Gorge Wine Association website, the Columbia Gorge wine region has grown to more than 45 vineyards, 30 wineries with at least 31 separate grape varieties planted in the region (Columbia Gorge Wine Association, 2012). The number of wineries and vineyards has continued to increase within the CGWR since 2012, and the present day summary is found in the results section. 


\section{CHAPTER 3: METHODS}

\subsection{Growers' Survey}

During the summer of 2013, a grower survey was conducted to determine the current locations of vineyards and wineries within the CGWR. This survey was designed to capture grape variety information that would help to describe the overall terroir and also to collect production information associated with each winery and vineyard that would serve as general background information for the wine region. The survey started with a list of growers and wineries from the Columbia Gorge Wine Association website (Columbia Gorge Wine Association, 2012) who were contacted by phone, email and mail to participate in the survey. Once interviewed, vineyard and winery owners were asked to provide contact information for owners not included on the CGWA list. Vineyard sites and wineries found while driving to survey interviews were also included in this study, and the owners were approached or contacted by mail to participate in the survey.

Each survey, filled out on site or by correspondence, consisted of collecting the Global Positions System (GPS) location of each winery or vineyard, taking pictures of the site, and interviewing the owners, managers or tasting room staff on information specific to each site. Questions related to the vineyard site included: first year of planting, the total acreage of the site, the grape varieties grown and corresponding acreage, the average tons per acre, the root stock (either self-rooted or grafted), irrigation practices, and any knowledge pertaining to the topography, climate and soil at the site. Information collected for the wineries included: the first year established, the vineyard sources, the 
wines currently being produced and the average amount of cases produced each year. The collected survey information was entered and stored in Microsoft Excel, to begin the first step in building a vineyard database for the region.

\subsection{GIS Analysis-Defining factors of the terroir}

\subsubsection{Defining the thesis area}

The boundaries of the Columbia Gorge AVA and Columbia Valley AVA were traced from an existing shapefile found in ArcGIS Online (Environmental Systems Research Institute; Peale, 2013). The existing shapefile contains all 2013 AVA boundaries in Washington State and was created using Federal register documents and referenced digital raster graphics (Peale, 2013). The traced boundaries were stored as a shapefile using the Environmental Systems Research Institute Geographic Information System (GIS) suite of applications, Arc Map 10.1. The Alcohol and Tobacco Tax and Trade Bureau (TTB) descriptions for the Columbia Gorge AVA were drawn in Google Earth using Google imagery and downloaded township and range grids from Earth Point Corporation to provide a reference (Bugenhagen, 2008). The boundaries formed in Google Earth were visually compared to the traced AVA boundary to further validate the boundaries.

GPS locations of vineyard sites collected during the survey were imported into GIS, and a new polygon layer was created that would be used for further analysis. Each individual vineyard block was traced on aerial photographs provided by the National Agriculture Imagery Program (NAIP) and saved into the new polygon layer (Figure 9). 


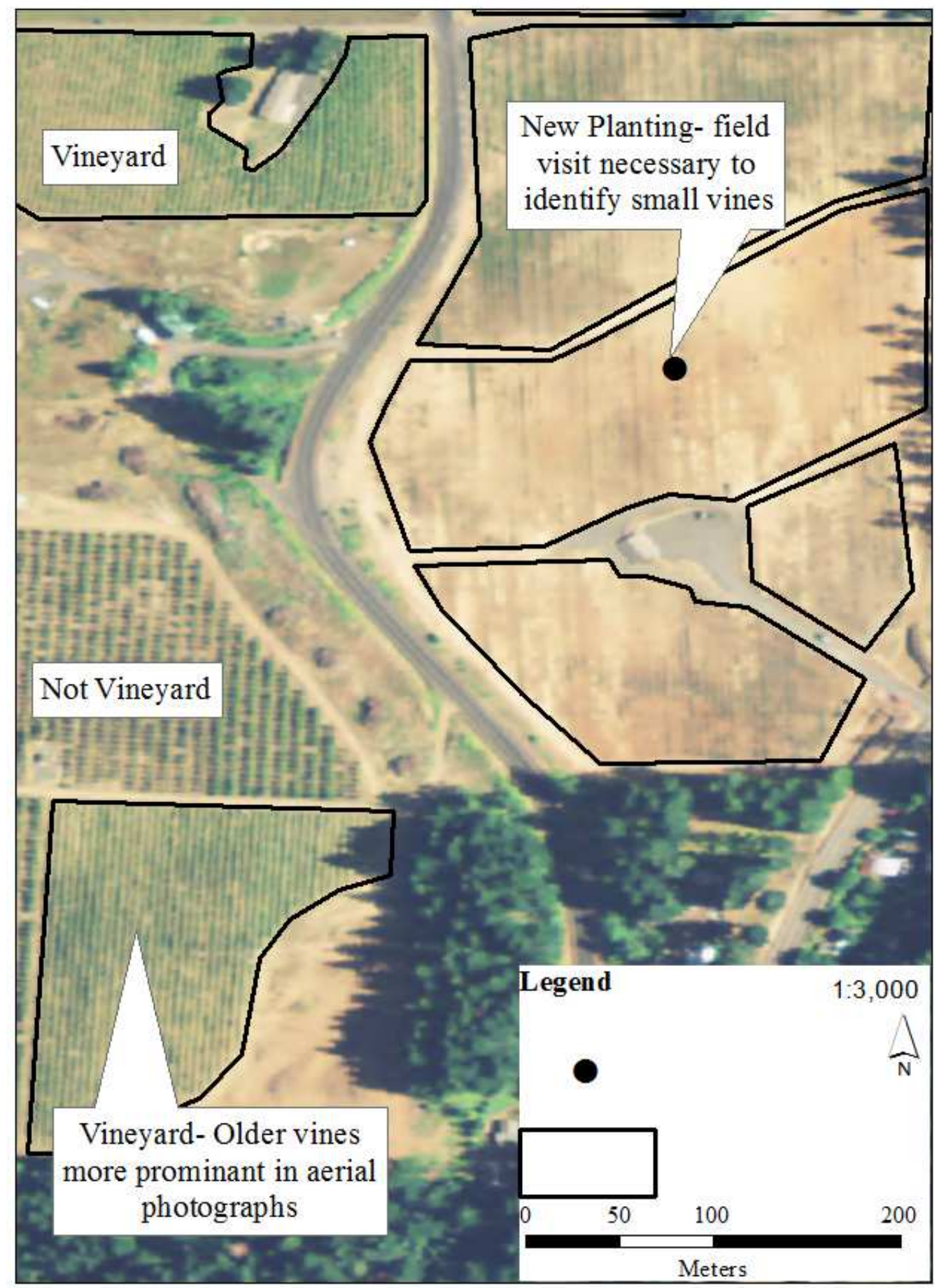

Figure 9. Aerial Photographs from the National Agriculture Imagery Program (NAIP) were used to trace vineyard boundaries once GPS locations were imported into Arc Map. This example shows Ziegler Brothers Family Vineyard (top left), Columbia River View Vineyard (new planting example) and Underwood Mountain Vineyards (bottom left). 
The NAIP, administered by the USDA Farm Service Agency (FSA) acquires imagery during the agricultural growing seasons when foliage is present, making the vines easier to identify therefore boundaries easier to trace (Barnard, 2009). The most recent year of NAIP Imagery for Oregon (2012) and Washington (2013) were added to GIS by connecting to the Aerial Photography Field Office (APFO) online server (http://gis.apfo.usda.gov/arcgis/services). To minimize distortions in the area calculations, the shapefile was projected into the Universal Transverse Mercator (UTM) North American Datum (NAD) 1983 projection. The area of each vineyard site was calculated in this projection using the calculate geometry tool in the Editor toolbox. The area, given in units of both acres and hectares, was checked with acreage estimations collected during the interviews to help validate the calculation.

\subsubsection{Defining the soil -NRCS data}

Soil vector data was downloaded from the Gridded Soil Survey Geographic (gSSURGO) Database for Oregon and Washington using the Geospatial Data Gateway website (http://datagateway.nrcs.usda.gov/). The statewide gSSURGO databases were derived from the Soil Survey Geographic (gSSURGO) Database (Soil Survey Staff, 2012a, b). The SSURGO database contains soil information collected by the National Cooperative Soil Survey, led by the National Resource Conservation Service (NRCS) and is generally the most detailed level of soil data in the United States (Soil Survey Staff, 2012a, b). The gSSURGO data were formed by merging SSURGO digital vector data into statewide extends (Soil Survey Staff, 2012a, b). The gSSURGO database also contains tabular data that represents soil attributes stored in the National Soil Information 
System (Soil Survey Staff, 2012a, b). The data from the gSSURGO database used for this project includes soils data from the Hood River, Wasco, Sherman, Skamania and Klickitat counties, originally collected at a scale of 1:20,000 to 1:24,000 (Soil Survey Staff, 2012a, b).

Soil polygons and attribute tables from the gSSURGO database for Oregon and Washington were imported into GIS, and the vector data were joined with multiple attribute tables to extract information used to describe the terroir (Figure 10). Once the attribute tables were joined, the Oregon and Washington soil polygons were merged together using the Merge tool in the Data Management toolbox, and soil information was extracted for individual vineyard blocks, using the Clip tool located in the Data Management toolbox. The area of each soil map unit was calculated in UTM NAD 1983 projection using the field calculator tools.

The clipped soil data for individual vineyards were exported to Excel as a text file, where further analysis of the dominant soil attributes were based on acreage calculations. The soil series, texture and soil order were also spatially analyzed to determine how often a given characteristic was located at a given vineyard. The dominant soil series, soil texture and soil order with the highest overall acreage located at the highest number of vineyards were determined as the dominant soil features for the region.

To add the dominant soil series to the vineyard database in Excel, the vector gSSURGO data were converted to a raster format. The raster data were converted in the Albers Equal Area projection to have a cell size of ten meters using a cell assignment of maximum area, meaning the cell would be assigned the value of the attribute with the 


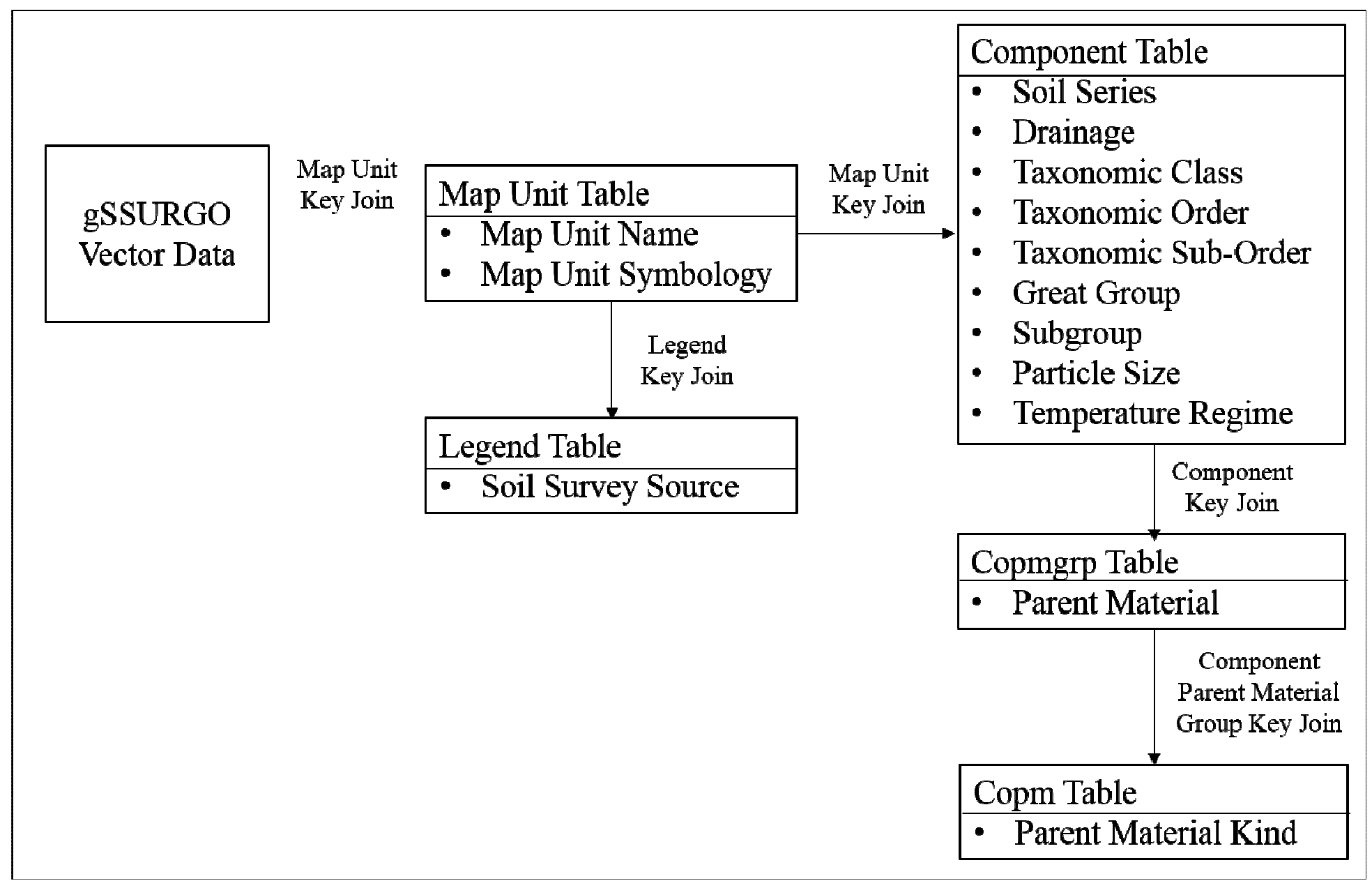

Figure 10. The soil vector data taken from the gSSURGO database were joined with a series of attribute tables in order to collect the adamant soil information to define the terroir of the CGWR (Soil Survey Staff, 2012a, b). 
largest area within the cell. A number code was assigned to each soil type after conversion to a raster. The major soil type at each vineyard block was summarized using the Zonal Statistics as Table tool in the Spatial Analyst toolbox. The resulting table included one number for each vineyard block, representing the major soil type. The soil series names were joined to each number code, which were then joined again to vineyard boundary polygon layer. Soil series for each vineyard block were permanently added to the vineyard shapefile, to be later imported into the vineyard database in Excel.

\subsubsection{Soil Field Work}

Each vineyard site was re-visited in October 2013 to validate gSSURGO map units using Soil Web, a smartphone application that combines the USDA-NRCS digital soil survey data with the GPS included on the smartphone. The application provides a cross sectional view of the soil horizons for each soil series, as well as the soil taxonomy descriptions, including the: order, suborder, great group, subgroup, family, soil series, phase and land classification. After spatially analyzing the soil data and performing the site visits, it was apparent that individual soil series dominated certain regions within the CGWR. Soil sub-regions were then drawn in GIS around areas with one or more dominant soil series. If one or more soil series was $90 \%$ contained in a specific region, then boundaries were drawn to include those series.

Soil pits were dug in October, 2013 at sites containing a characteristic soil series for each soil sub-region. A 3 -feet ( 0.9 meter) deep by 3 -feet ( 0.9 meter) wide soil pit with vertical sides was dug at selected vineyard sites in order to describe the soil profile. Horizons, distinctive in color and texture, were identified in the soil profile and measured 
for depth. The wet-color of each horizon was identified in the field using a Munsell Color Book, and texture was described using the texture-by-feel method (Birkeland, 1999). Pictures of the soil profile and soil samples from both the A horizon and B horizon were taken at each soil pit. A taxonomic subgroup was recommended for each soil pit using field observation and the Keys to Soil Taxonomy (Soil Survey Staff, 2010). If the field subgroup classification was different than the NRCS classification, a new soil series was recommended by analyzing other soil series in the region.

\subsubsection{Soil Laboratory Work}

Soil samples were taken to the soils lab in the Geology Department at Portland State University and analyzed for the dry color and $\mathrm{pH}$. Each sample was first placed into a drying oven for 24 hours before analysis took place. Once completely dry, the dry color

was identified in the lab using a Munsell Color book. To determine the $\mathrm{pH}$, first $10 \mathrm{~cm}^{3}$ of soil was added with $10 \mathrm{ml}$ of distilled water in a $50 \mathrm{ml}$ glass beaker. The combined solution was mixed with a glass rod and the solution sat for 5 minutes. A pH 211 Microprocessor $\mathrm{pH}$ meter was used to electronically record the $\mathrm{pH}$ to a unit of 0.01 , and then rounded to one place past the decimal. The $\mathrm{pH}$ probe was calibrated using colorcoded buffer solutions of $\mathrm{pH} 4.0$ and 7.0 before the initial measurements, and the probe was washed with distilled water between each recording.

\subsubsection{Characterizing the Geology-Geological Maps and Soil Surveys}

Geological maps used to determine the geology at each vineyard sites were accessed from the National Geological Map Database, created by the United States Geological Society (USGS) and Association of American State Geologists. The 
geological maps used for this study range in scale from 1:36,000 to $1: 100,000$ and include the most updated maps for the Hood River Valley, Oregon and Washington (Ma et al., 2009; McClaughry et al., 2012a; Washington State Department of Natural Resources Staff, 2010). Each map was imported into GIS and merged together using data management tools. Similar geological units across all three maps were consolidated into one shapefile, to form one geological map for the wine region. The consolidated shapefile was converted to a raster file, and the major geological mapping unit was calculated for each vineyard site using the Zonal Statistics as Table tool in the Spatial Analyst toolbar. The major geological mapping unit for each vineyard site was then added to the database in Excel.

The parent material provided in the gSSURGO database for each map unit was used to determine the extent of loess at vineyard sites (Soil Survey Staff, 2012a, b). The attribute table containing the parent material for each soil map unit was joined to the soil vector data during the process of determining the mapped soil units at each vineyard. An attribute table separated the parent material by common lithology (parent material kind) and map units predominantly formed in loess were labeled "Loess" is this table. The acreage of soil maps units that were dominantly formed in loess was calculated in Excel, and the number of vineyards containing loess in the parent material was spatially determined in GIS.

\subsubsection{Characterizing the Topography}

The National Elevation Dataset (NED) was used to characterize the topography at vineyard sites in GIS. The NED was created by the United States Geological Society 
(USGS) and accessed through the National Map Viewer and Download Platform program. This dataset is a mosaic of best-available elevation data drawn from a variety of data sources, including USGS 7.5-minute series Digital Elevation Models (DEM's) and remote sensing technologies (United States Geological Survey, 2013a; United States Geological Survey, 2013b). The assemblage of elevation data results in a raster dataset in which each cell has a value that corresponds to an elevation at the surface. The NED is distributed as 1-degree quadrangles, with decimal-degree geographic coordinates referenced to the North American Datum of 1983 (NAD83) and elevation values in meters, referenced to the North American Datum of 1988 (NAVD88) (United States Geological Survey, 2013a; United States Geological Survey, 2013b).

The downloaded NED for the thesis area included two quadrangles, both at $1 / 3$ arc second ( $\sim 10$ meter) resolution (United States Geological Survey, 2013a; United States Geological Survey, 2013b). The two tiles were joined together in GIS using mosaic tools in the data management toolbox, resulting in one combined elevation raster dataset. The combined elevation raster was projected into UTM NAD 1983 coordinates in order for all the axes to be in the same units.

The spatial analyst surface tools were used to create aspect, slope and curvature surfaces from the combined raster. The Zonal Statistics as Table tool in the Spatial Analyst Toolbox was used to calculate the mean and corresponding standard deviation, minimum and maximum elevation and slope values for each vineyard block. The resulting tables for elevation and slope were temporary joined to the vineyard polygon layer in order to permanently add the values to the vineyard block shapefile. 
Calculating the aspect presented a new problem when averaging two directions using zonal statistics. For example, averaging 359 and 1 yields 180 , resulting in an aspect value that will appear to be due south instead of close to north. The aspect values were therefore reclassified in order to obtain useful results following methods provided by Barnard (2009). The Reclassify tool within the Spatial Analyst Toolbox was used to convert azimuthal values for northern directions (337.5 to 22.5), northeastern directions (22.5 to 67.5 degrees), eastern directions (67.5to 112.5$)$, southeastern directions (112.5 to 157.5), southern direction (157.5 to 202.5 degrees), southwestern directions (202.5 to 247.5), western directions (247.5 to 292.5 degrees) and northwestern directions (292.5337.5) to $1,2,3,4,5,6,7$ and 8 respectively. The Zonal Statistics as Table Tool was used again to summarize the majority and minority aspect pixel values within each vineyard block. These values were also added to the vineyard shapefile using the Join tool. In addition, the variety of aspects pixel values was calculated and added to each vineyard shapefile. The variety indicated the number of different aspects represented in each vineyard block but did not indicate which specific aspect values were represented.

When the pixel values are negative, the curvature is considered concave compared to its neighbors, flat when the value is between 1 and -1 , and convex when the pixel values are positive. The curvature surface raster was also reclassified for ease of finding majority curvature for each vineyard block (Barnard, 2009). All negative values were reclassified as -1, zero values remained zero, and all positive values were reclassified as +1 . The Zonal Statistics as Table Tool was then used to determine the majority curvature 
pixel value for each vineyard, and the Join tool is used to add these values to its field in the vineyard shapefile.

\subsubsection{Characterizing the Climate}

The PRISM dataset is created as 15 arc-second ( 400m, 1312ft) grids through an interpolation method that incorporates a comprehensive collection of climate stations from many networks (Daly et al., 2008). PRISM takes into account the location, elevation, coastal proximity, topographic facet orientation (aspect), vertical atmospheric layer, topographic and orographic position of the terrain (Daly, 2008; Jones et al., 2004). PRISM has been used for other viticultural studies in the western United States and has been validated using remote sensing vineyard locations (Jones et al., 2010).

The PRISM dataset used for this study includes monthly precipitation and maximum and minimum temperature rasters (400m resolution) from 1981-2010. Monthly precipitation rasters were summarized for annual and growing season (April-October) periods using the field calculator in the GIS toolbox. Monthly maximum and minimum temperature rasters were processed into (1) growing degree days (GDDs, $\mathrm{C}^{\circ}$ units) from April to October using a base temperature of $10^{\circ} \mathrm{C}\left(50^{\circ} \mathrm{F}\right)$ and (2) average growing season temperatures (GST, $\mathrm{C}^{\circ}$ units) from April to October using equations provided in Table 1. The exact equations used in the field calculator to calculate the GDD and GST from the PRISM grids are provided in Appendix B. A new raster grid containing GDD and GST values was classified by the criteria set for each climatic regime (Table 1; Jones et al., 2010). 
The 400 meter resolution PRISM data was too small of a scale to calculate statistics for a vineyard block using the Zonal Statistics as Table tool in the Spatial Analyst Toolbox. Therefore, the GDD and GST raster data were converted to a shape file, and the mean and corresponding standard deviation, variance, minimum and maximum values were calculated when spatially joining the PRISM data to the vineyard boundary shapefile. The resulting tables were temporarily joined to the vineyard polygon layer in order to permanently add the values to the vineyard block shapefile. 


\section{CHAPTER 4: RESULTS}

\subsection{The Growers' Survey}

Thirty-seven wineries were identified by the growers' survey in 2013. Twentyfive wineries are located in the Columbia Gorge AVA, ten are in the Columbia Valley AVA, and one winery is located outside of both AVAs (Figure 11). Pinot Noir is the most common type of wine produced at wineries in the CGWR, followed by Chardonnay and Syrah (Appendix B - 1). Winemakers in the CGWR source their grapes from vineyards in the CGWR, Willamette Valley AVA, the Horsehaven Hills AVA, Walla Walla AVA, Rattlesnake Hills AVA, Red Mountain AVA, and the Yakima Valley AVA (Appendix B3). Some wineries in the past recorded sourcing grapes from regions as far as California (Appendix B - 3).

The average amount of cases produced each year by wineries in the CGWR ranges from $300-500$ cases at smaller production sites, to more than 100,000 cases at the largest production wineries (Appendix B - 3). Four wineries, including Aniche Cellars, Cascade Cliffs Winery, Domaine Poullion and Syncline Winery, conduct biodynamic practices in the vineyard and winery. At least five wineries conduct organic practices in the winery (Hood Crest Winery, Klickitat Canyon Winery, Pheasant Valley Winery, Phelps Creek Winery and Pour Moore Wine Winery) and as of 2013, Klickitat Canyon Winery is the only certified organic winery (Appendix B - 2).

As of September 2013, there are 82 vineyard sites within the CGWR (Appendix B - 3). Out of the 82 vineyard sites found in this study, 56 are located within the Columbia 


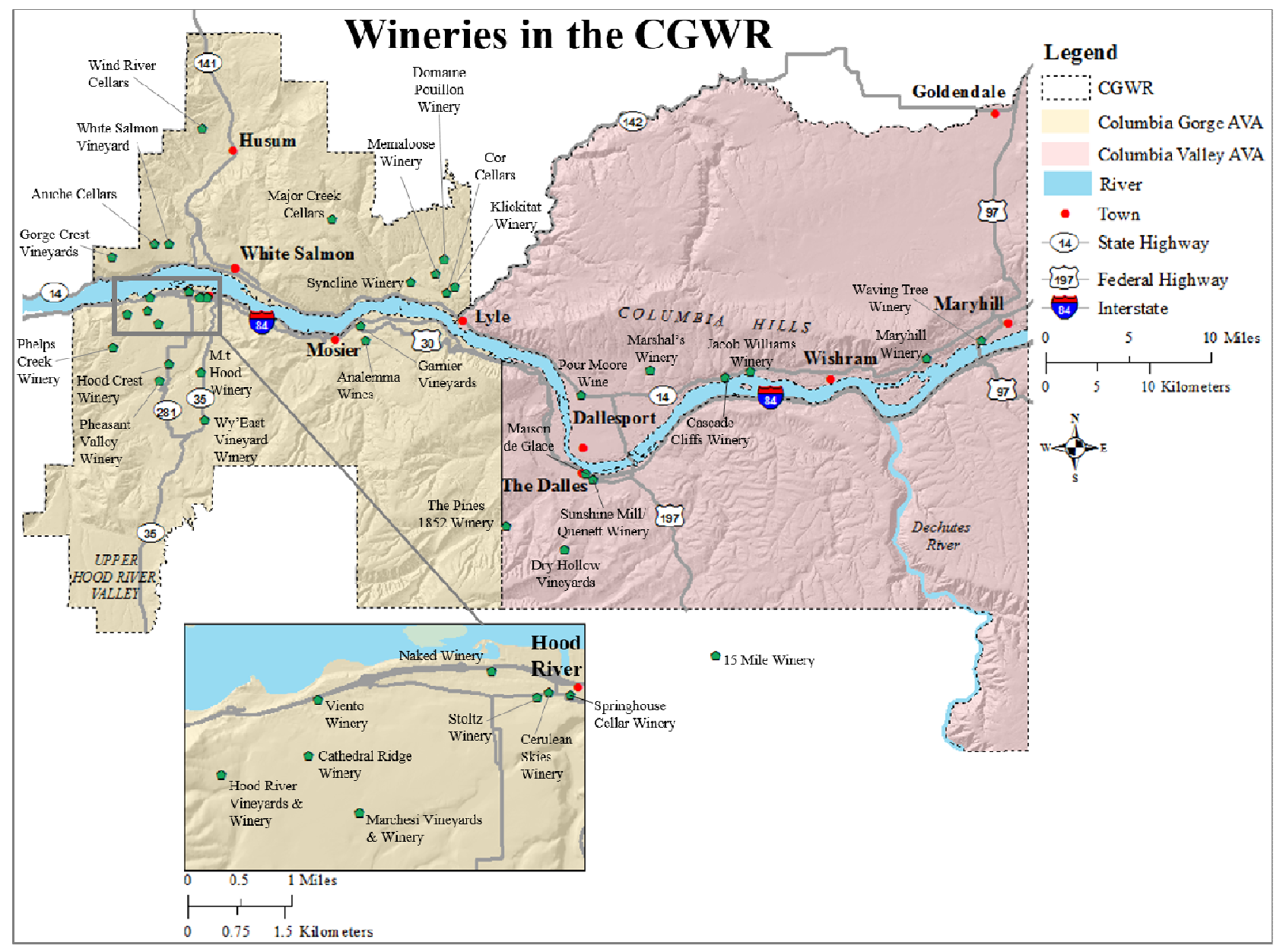

Figure 11.37 wineries are located in the CGWR with one winery (15 Mile Winery) outside of the AVA boundaries, 24 wineries in the Columbia Gorge AVA and 10 in the Columbia Valley AVA. 
Gorge AVA boundary and 24 lie within the Columbia Valley AVA (Figure 12). One vineyard (Deer Run Family Farm and Vineyard) is located completely outside the CGWR and two vineyards are located on the Columbia Gorge AVA boundary; one on the northeast boundary near Underwood Mountain (Pear Blossom Vineyard), and the other on the boundary between the Columbia Gorge AVA and the Columbia Valley AVA, near The Dalles, Oregon (The Old Pines Vineyard; Figure 12).

Out of the 82 vineyards found in the survey, 72 sites located within the CGWR completed responses to the survey questionnaire. Some growers chose not to answer every question in the grower's survey, and therefore the number of responses for each question varies.

In total, 41 grape varieties are planted in the 70 vineyards within the CGWR. The grape variety estimates provided by the vintners total to 386 hectares (954 acres). About half (21) of the grape varieties account for $98 \%$ of the total estimated grape variety acreage. Pinot Noir is the most widely planted variety among the 70 vineyards and accounts for $31 \%$ of the total estimated acreage in the CGWR. Syrah, Chardonnay, Pinot Gris and Zinfandel are also common varieties and represent another $30 \%$ of the total estimated grape variety acreage (Figure 13).

There are 36 varieties planted in the Columbia Gorge AVA. Cool (early) varietals such as Pinot Noir, Chardonnay, Pinot Gris, Gewürztraminer, and Riesling dominate in the Columbia Gorge AVA and account for $71 \%$ of the total estimated grape variety acreage (Figure 13; Appendix B - 5). In the Columbia Valley AVA, Pinot Noir, Syrah, and Merlot compromise 54\% of the estimated grape variety. For the exception of Pinot 


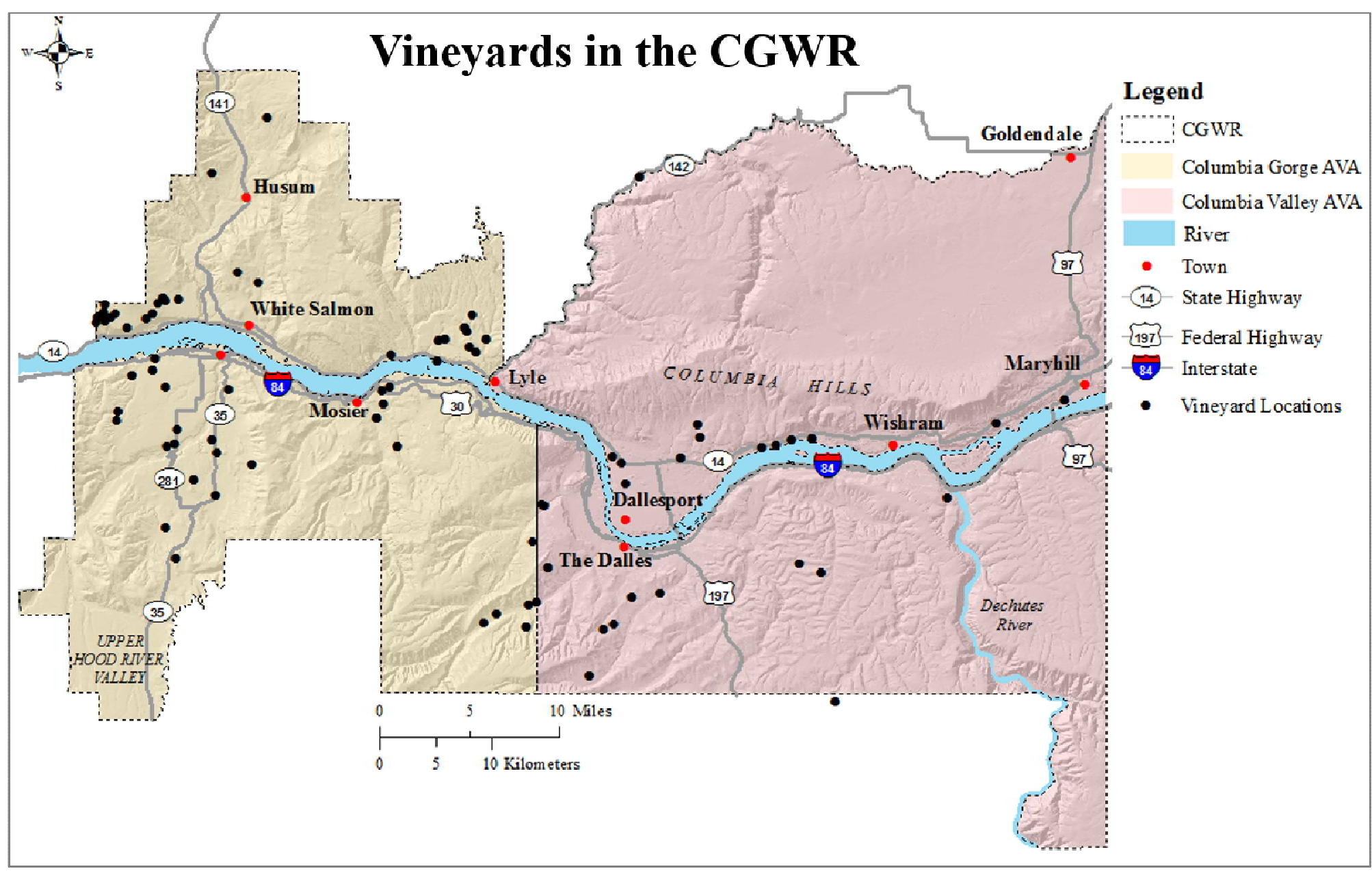

Figure 12. As of 2013, there are 82 vineyards located in the CGWR and one vineyard (Deere Run Family Vineyard) outside the CGWR. 


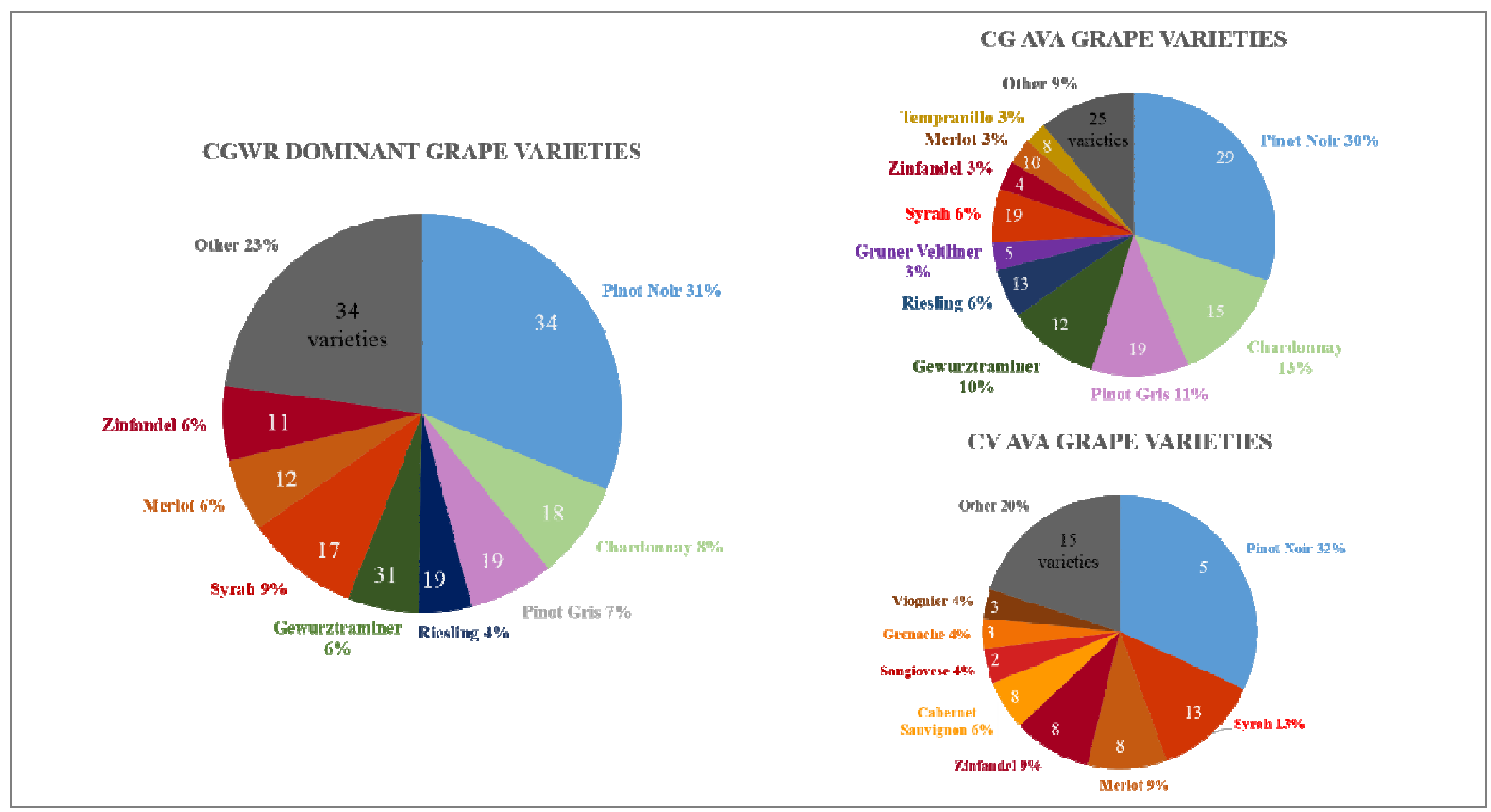

Figure 13. Percentages are based on acreage estimations provided by vintners during the grower's survey. The numbers within each pie chart represent the number of vineyards that have planted each grape variety Pinot Noir is the mostly widely planted grape within the CGWR. Other cool varieties (labeled green, blue or purple) that dominate the CGWR include Chardonnay, Pinot Gris, Riesling and Gewürztraminer. Warm varieties (labeled red, orange or yellow) that dominate in the CGWR include Syrah, Merlot and Zinfandel. In general, the Columbia Gorge (CG) AVA is dominated by early varietal grape varieties (74\%) while for the exception of Pinot Noir, the dominate grape varieties in the Columbia Valley (CV) AVA are warm varietals (45\%). 
Noir, warm varieties dominate the Columbia Valley AVA (Figure 13; Appendix B - 5). Twenty-five different grape varieties are planted in the Columbia Valley AVA (Appendix B - 5).

Yields among 68 vineyards range from 0.5 to 6.0 tons/acre, with the average yield being $2.7+/-1.2$ tons/acre (Appendix B - 2). Out of the 83 vineyards, 10 vineyards $(12 \%)$ are fully grafted, 37 vineyards (45\%) are self-rooted, 15 vineyards (18\%) are partially grafted and partially self-rooted and 21 vineyards (25\%) contained no response (Appendix B - 2). The varieties of rootstocks used by vineyards that were grafted include 3309, 5C Teleki and 101-14. Dry-land farming irrigation takes place among 24 vineyards ( $29 \%$ of the total number of vineyards), all located within the Columbia Gorge AVA (Figure 14; Appendix B - ). Irrigation during the growing season takes place among 34 vineyards ( $42 \%$ of the total number of vineyards) and irrigation information was not provided for 24 vineyards $(29 \%)$.

The 82 vineyards surveyed compromise 374 individual vineyard blocks totaling to 513.0 hectares (1268 acres). The total vineyard block acreage outside of the CGWR is 8.3 hectares (20.6 acres), totaling to 504.5 hectares (1246.8 acres) of vineyards planted within the CGWR. The size of vineyards in the region range from small vineyard plots of 0.5 acres ( 0.2 hectares) to large production vineyards between 50 acres (20 hectares) and 297 acres (120.2 hectares) in size (Appendix $\mathrm{C}-1)$.

Three vineyards representing 125 hectares (308 acres) were not yet planted when the survey was conducted. One of these vineyards includes the largest vineyard in the 


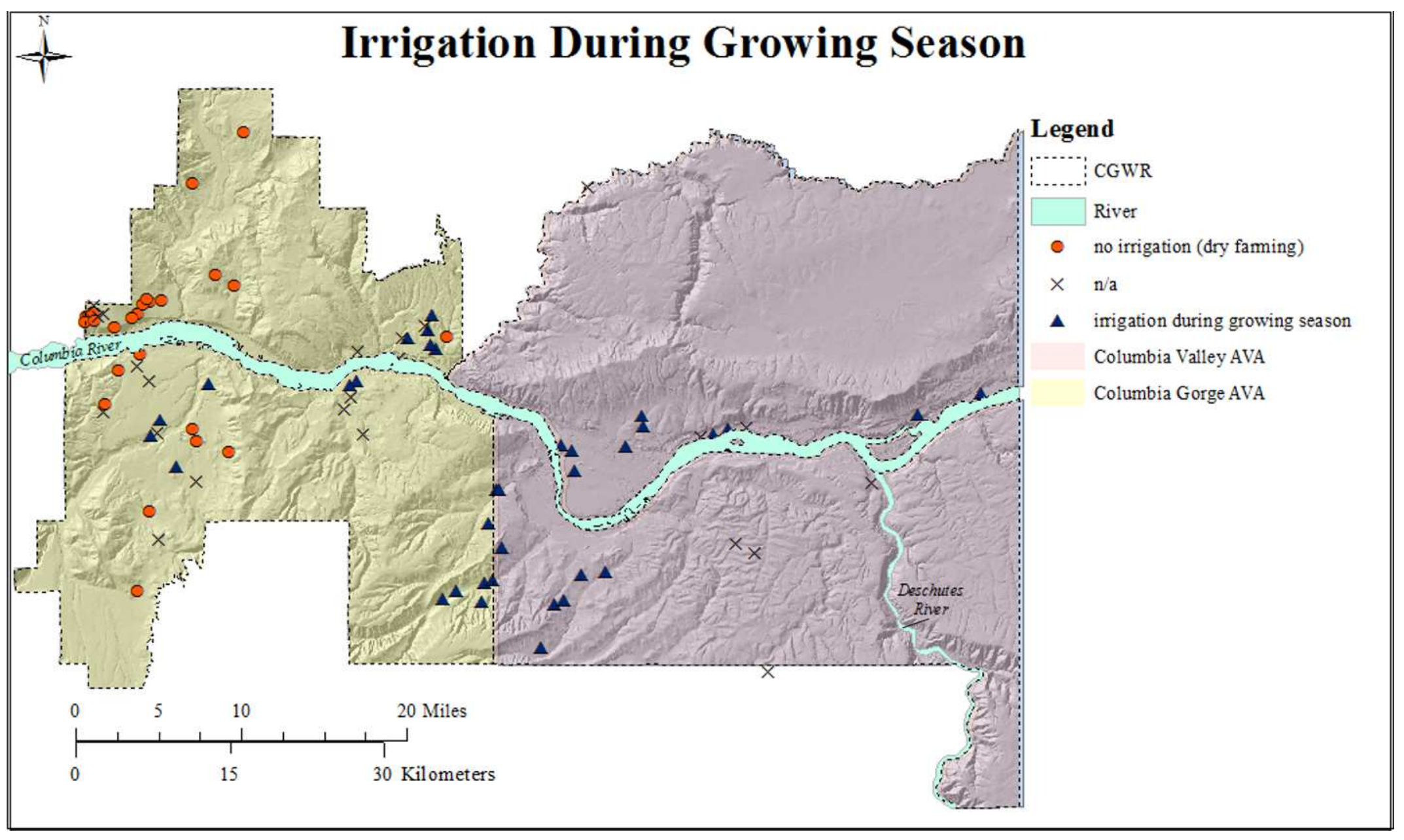

Figure 14. Majority of the vineyards that have dry farming practices (no irrigation during the growing season) are located in the western portions of the study area (orange circles). 
region, Sunshine Mountain Vineyard (297 acres or 120 hectares). Boundaries for this site were drawn using photographs that showed the locations of the final vineyard block plantings. It is estimated that since the survey, roughly 130 acres (52 hectares) of Pinot Noir grapes have been planted at this site (verbal communication, Lonnie Wright, August 2014).

\subsection{Topography of the CGWR}

The elevation of vineyards within the CGWR ranges from a low of 29 meters (95 feet) at Garnier Vineyards near Mosier, Oregon to a high of 548 meters (1799 feet) at Atavus Vineyards near White Salmon, Washington (Appendix C - 1)..The highest and lowest elevated vineyards are both located in the Columbia Gorge AVA. The elevation at vineyards in the Columbia Valley AVA range from 51.3 meters (168.0 feet) at Waving Tree Vineyards near Maryhill, Washington to 396.2 meters (1300 feet) as proposed at Volcano Ridge vineyard, south of The Dalles, Oregon (Appendix C- 2; written commun. Alan Busacca, 2015). Vineyard blocks located outside of the CGWR (Pear Blossom Vineyard \& Deere Run Family Vineyard) ranges between 325.0 meters (1066.4 feet) to 406.8 meters (1334.5 feet) (Appendix C- 3). The elevation range within each vineyard block in the CGWR ranges from 0.0 at sites less than 0.4 hectares (one acre) in size, to 93 meters (303 feet) at the largest vineyard block that is 108 hectares (266 acres) in size (Appendix $\mathrm{C}-1)$.

Values for the slope measured at vineyard blocks within the CGWR boundaries range from $0^{\circ}(0$ percent rise or $\%)$ to $31.0^{\circ}(60.0 \%$ percent rise or $\%)$; the average slope is $7.1^{\circ}+/-4.2^{\circ}(12.6 \%+/-7.5 \%$; Appendix C- 1$)$. The mean slope of the Columbia Gorge 
AVA $6.9^{\circ}+/-4.1^{\circ}(12.2 \%+/-7.4 \%)$, and the mean slope among vineyard blocks in the Columbia Valley AVA is $7.4^{\circ}+/-4.3^{\circ}(13.2 \%+/-7.7 \%)$ (Appendix C- 3; Appendix C2).

Twenty-nine percent of the vineyards in the CGWR have east aspects, whereas $25 \%$ have southeast aspects, $14 \%$ have south aspects, and $10 \%$ have southwest aspects (Appendix C- 1). Other aspects of vineyards in the CGWR are as the following: westerly (9.1\%), northerly (4.8\%), northwesterly (4.1\%), and northeastern (3.3\%). The dominant aspect at vineyard blocks in the Columbia Gorge AVA only are southeast (26.6\%), south (15.9\%), east (15.9\%) and southwest (14.4\%) and the dominant aspect at vineyard blocks in the Columbia Valley AVA are east (41.2\%), southeast (23.7\%), south (13.0\%), and west (8.2\%) (Appendix C- 2; Appendix C- 3). 55\% of the vineyard blocks in the CGWR are flat whereas $13 \%$ are flat and concave topography, $14 \%$ are flat and convex topography, and $18 \%$ are located on a mixture of flat, convex and concave topography (Appendix C- 1).

\subsection{Climatic Conditions in the CGWR}

Annual precipitation as defined by the 1981-2010 PRISM dataset declines from 118.6 centimeters (46.7 inches) in the Upper Hood River Valley, to 27.4 centimeters (10.8 inches) east of Dallesport, Washington (Figure 15). Vineyards located on Underwood Mountain and in the Upper Hood River Valley receive the highest amount of annual precipitation of roughly 95 centimeters ( 37 inches).

The growing season precipitation in the CGWR ranges from 4.3 centimeters (1.6 


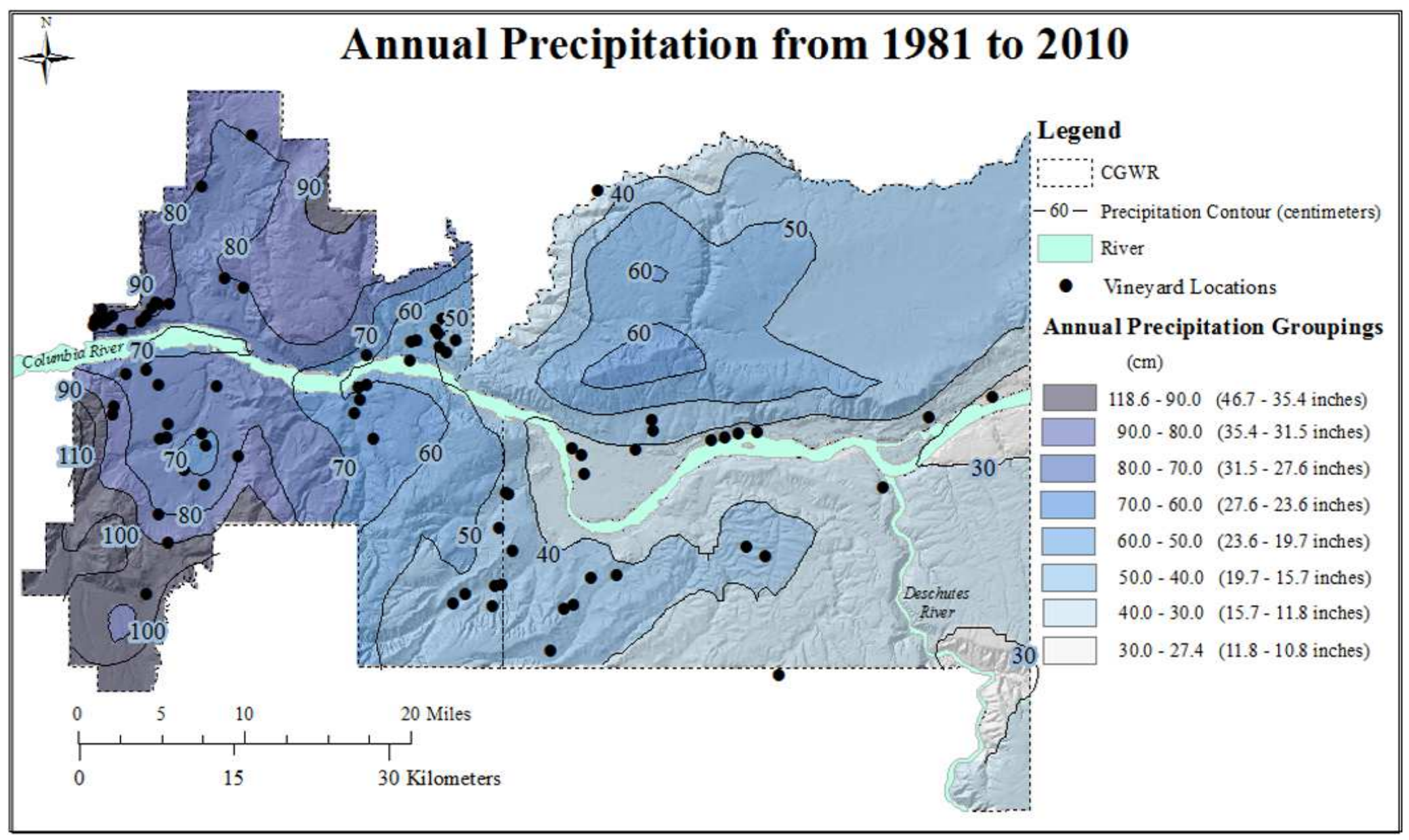

Figure 15. The annual precipitation in the CGWR decreases from over 100 centimeters ( 40 inches) in the south-western boundaries, to less than 30 centimeters $(<10.8$ inches) in the eastern portions near the Columbia River and Deschutes River 
inches) in the western most boundaries near the Upper Hood River Valley, to 1.1 centimeters ( 0.7 inches) in the eastern boundaries from 1981 to 2010 (Figure 16). The highest amount of growing season precipitation measured among the vineyards is 3.4 centimeters (1.3 inches) and on average, vineyards in the CGWR receive $2.1+/-0.7$ centimeters of precipitation during the growing season. (Appendix C-1). Vineyards that practice dry-land farming are usually in regions with more than 2.0 centimeters of precipitation (Figure 16). An exception is at Klickitat Vineyard near Lyle, Washington, which practices dry-land farming in a region that generally receives less than 2.0 centimeters (Figure 16).

Average growing season temperatures (GST) calculated from the 1971-2010 PRISM data (Daly, 2012a; Daly, 2012b) range from $12.9^{\circ} \mathrm{C}\left(55^{\circ} \mathrm{F}\right)$ to $17.8^{\circ} \mathrm{C}\left(64.0^{\circ} \mathrm{F}\right)$ within the CGWR. GST values range from $13.7^{\circ} \mathrm{C}\left(55.7^{\circ} \mathrm{F}\right)$ to $17.7^{\circ} \mathrm{C} .\left(63.9^{\circ} \mathrm{F}\right)$ at vineyards within the CGWR (Figure 16). The mean GST among vineyard in the CGWR is $15.6^{\circ} \mathrm{C}+/-6.7^{\circ} \mathrm{C}\left(60.1^{\circ} \mathrm{F}+/-22.3^{\circ} \mathrm{F}\right)$ (Appendix $\left.\mathrm{C}-1\right)$. GST values at vineyards within the Columbia Gorge AVA range from $13.7^{\circ} \mathrm{C}\left(56.7^{\circ} \mathrm{F}\right)$ to $16.9^{\circ} \mathrm{C}\left(62.4^{\circ} \mathrm{F}\right)$ and vineyards in the Columbia Valley AVA range between $15.0^{\circ} \mathrm{C}\left(59.0^{\circ} \mathrm{F}\right)$ to $17.7^{\circ} \mathrm{C}\left(63.9^{\circ} \mathrm{F}\right)$ (Appendix C- 2; Appendix C- 3). The mean GST at vineyards inside the Columbia Gorge AVA and Columbia Valley AVA are $15.0^{\circ} \mathrm{C}+/-6.3^{\circ} \mathrm{C}\left(59.0^{\circ} \mathrm{F}+/-22.0^{\circ} \mathrm{F}\right)$ and $16.6^{\circ} \mathrm{C}$ $+/-7.3^{\circ} \mathrm{C}\left(61.8^{\circ} \mathrm{F}+/-22.6^{\circ} \mathrm{F}\right)$ respectively (Appendix C- 2 ; Appendix C- 3$)$. The mean GST values calculated for vineyard blocks outside of the CGWR is $16.6+/-22.6^{\circ} \mathrm{C}$ $\left(61.8^{\circ} \mathrm{F}+/-22.6^{\circ} \mathrm{F}\right)$ and range from $15.0^{\circ} \mathrm{C}\left(59.0^{\circ} \mathrm{F}\right)$ to $17.7^{\circ} \mathrm{C}\left(63.9^{\circ} \mathrm{F}\right)$ (Appendix $\mathrm{C}-4$; Appendix C- 2; Appendix C- 3). The mean GST values calculated for vineyard blocks 


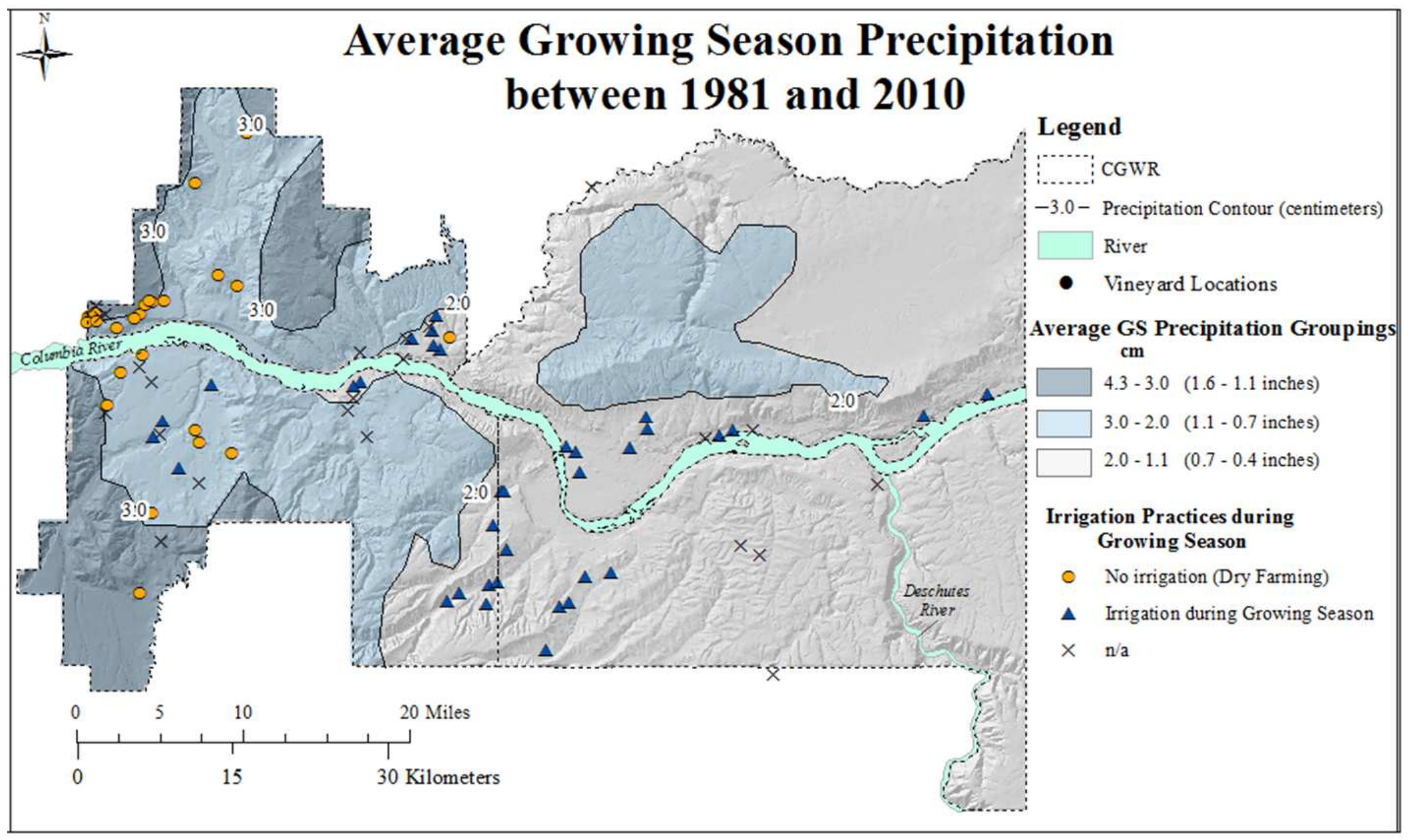

Figure 16. The average growing season precipitation calculated using 1981-2010 PRISM data was less than 4.0 centimeters (1.6 inches) between 1981 and 2010. For the exception of one vineyard, dry-farming irrigation is practiced among vineyards receiving $+\infty$ on average greater than 2.0 centimeters of precipitation during the growing season. 


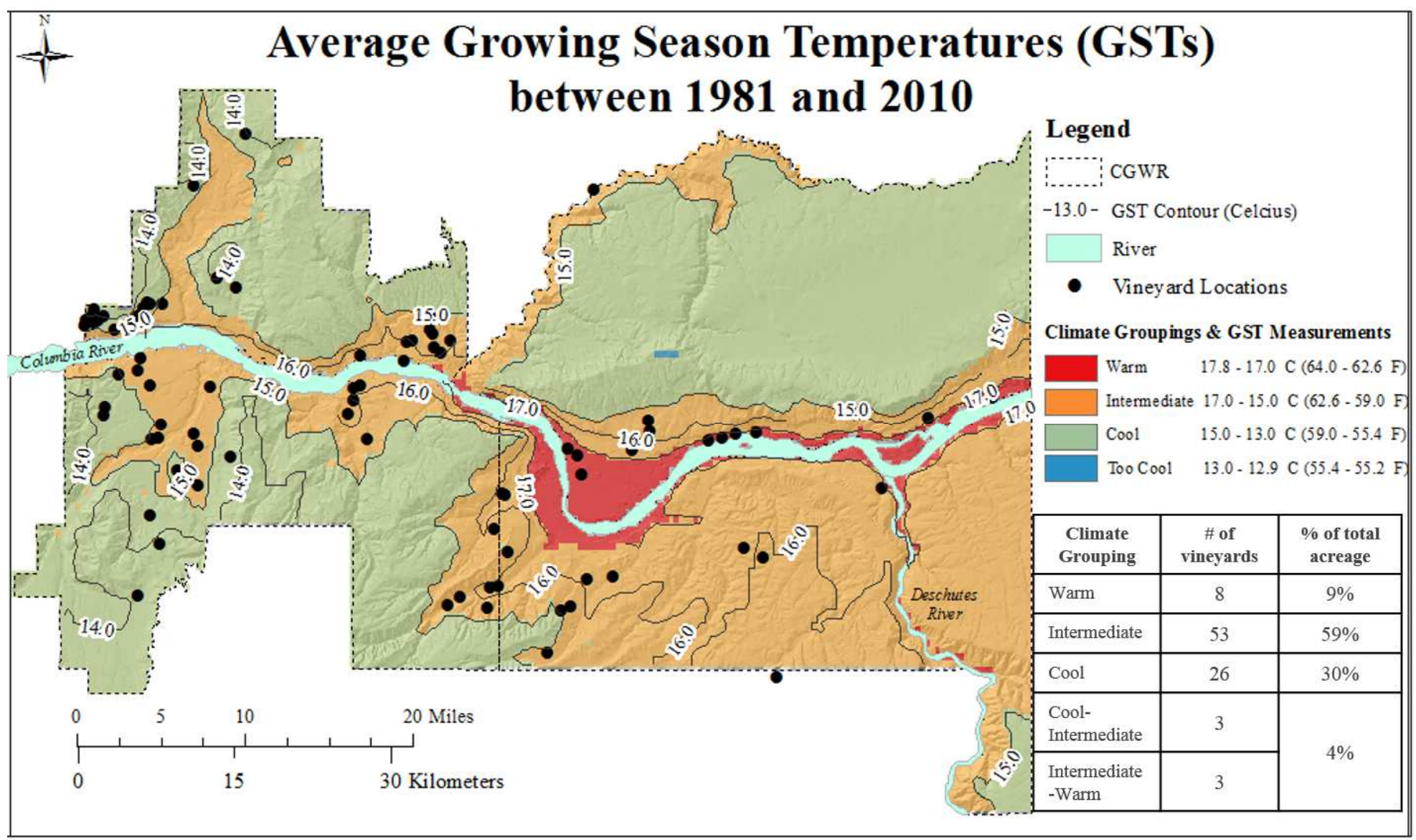

Figure 17. The climate groupings defined by average growing season temperatures (GSTs) range from cool to warm. Area too cool for viticulture are located outside the CGWR, and at the highest elevation in the Columbia Hills. Majority of the vineyards in the CGWR are located within an intermediate climate. The GST Measurements for each climatic grouping above have been adjusted to reflect GST values measured at each vineyard and are not the identical to the measurement groupings provided by Jones et al., (2010). 
outside of the $\mathrm{CGWR}$ is $16.6+/-22.6^{\circ} \mathrm{C}\left(61.8^{\circ} \mathrm{F}+/-22.6^{\circ} \mathrm{F}\right)$ and range from $15.0^{\circ} \mathrm{C}$ $\left(59.0^{\circ} \mathrm{F}\right)$ to $17.7^{\circ} \mathrm{C}\left(63.9^{\circ} \mathrm{F}\right)($ Appendix C- 4$)$.

Using GST values and criteria set by Jones (2005), four climatic regimes are classified within the CGWR (Figure 17). Regions that are too cool for growing grapes are limited to the very highest elevations in the Columbia Hills. Vineyards are only planted within cool, intermediate and warm climatic regimes (Appendix C- 1). Twenty-six vineyards are classified within a cool climate regime that compromise 326.5 acres or $30 \%$ of the total vineyard acreage. Almost all of the vineyards classified as a cool climate regime are located on Underwood Mountain, near Husum, Washington and near White Salmon, Washington. The exception includes one vineyard in the lower Hood River Valley mapped within a cool-climate regime (Figure 17).

Fifty-three vineyards are classified within an intermediate climatic regime, compromising 746.1 acres and 59\% of the total vineyard acreage (Appendix D-2). Vineyards characterized within the intermediate zone located in the Hood River Valley are at lower elevations, close to Hood River and the Columbia River. All of the vineyards located in Mosier, Lyle and near The Dalles are classed within an intermediate climate. Vineyards higher in elevation near Dallesport ( $>163$ meters), near Wishram $(>83$ meters) and near Maryhill ( $>170$ meters) are also within an intermediate zone (Figure 17).

Three vineyards (Celilo, Dampier and Pheasant Valley Vineyard) border the cool and intermediate climatic regimes in the western CGWR and three vineyards (Gunkel Vineyards- Maryhill site, Rapture Ridge LLC \& Waving Tree Winery) border the 
intermediate and warm climatic zones in the eastern CGWR (Figure 17). Vineyards that border the climatic regime boundaries sum to 57.6 acres and account for $4 \%$ of the total vineyard acreage.

The warm-climatic regime boundaries begin in Dallesport and extend eastward into Wishram and Maryhill along the Columbia River (Figure 17). Eight vineyards all at elevations below 233 meters are classified into a warm-climatic regime. Vineyards classified into a warm climatic regime sum to 110 acres and $9 \%$ of the total vineyard acreage.

GST values calculated for each vineyard block vary by elevation and by east to west locations (Figure 18). The lowest GST values $\left(13.8-14.0^{\circ} \mathrm{C}\right)$ are measured among vineyard sites located on Underwood Mountain, near White Salmon and in the upper Hood River Valley (above 448 meters). Vineyards with the highest GST $\left(17-17.4^{\circ} \mathrm{C}\right)$ values are located at low elevations near Dallesport and Maryhill $(<100 \mathrm{~m})$. Growing degree-days calculated from the 1981-2010 PRISM dataset range between 871 for ${ }^{\circ} \mathrm{C}\left(1567\right.$ for $\left.{ }^{\circ} \mathrm{F}\right)$ to 1664 for ${ }^{\circ} \mathrm{C}\left(2994\right.$ for $\left.{ }^{\circ} \mathrm{F}\right)$ at vineyards within the CGWR. Four Winkler Indices are characterized within the Columbia Gorge Wine Region (Figure 19). Regions too cool for growing Vitus Vinifera grapes (GDD between $755-850$ for ${ }^{\circ} \mathrm{F}$ ) are outside of the AVA boundaries and at the highest elevations. Calculated GDDs were classed into Region III at locations closest to the river near The Dalles. All of the vineyards within the CGWR are located in regions suitable for viticulture.

There are 26 vineyards located in Region Ia, compromising of 306 acres and 24\% of the total vineyard acreage (Figure 19). Forty vineyards are located in Region Ib while 


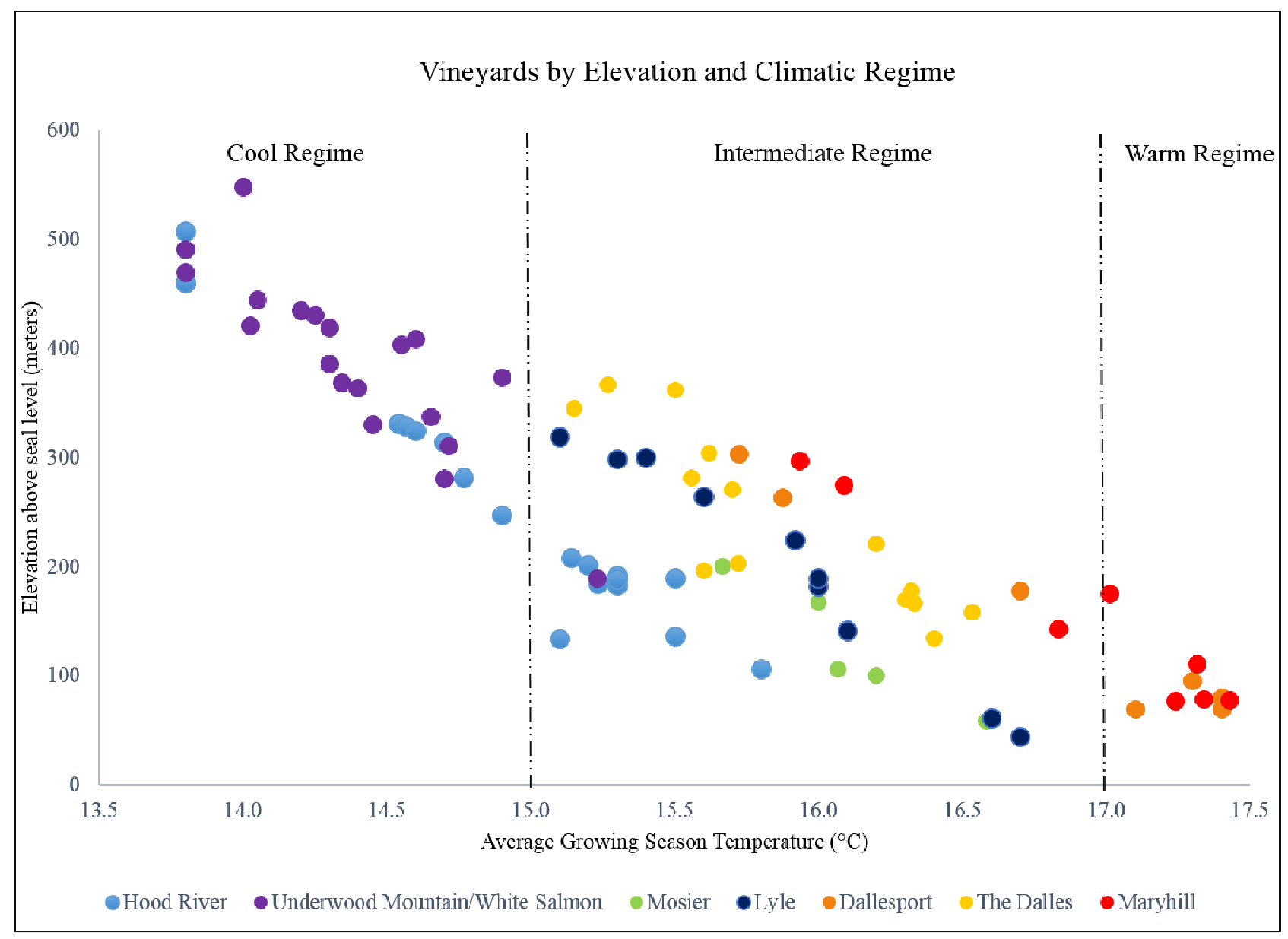

Figure 18. Vineyards in highest in elevation and in the coolest regimes tend to be in the western portions of the CGWR, while those on the eastern side tend to be lower in elevation and contain a warmer climate. Note that elevation is not directly related to each climatic regime, as vineyards in similar elevation on Underwood Mountain and in Mosier are characterized in different regimes. The climatic boundaries in the CGWR are dependent on both elevation and east and west locations. 


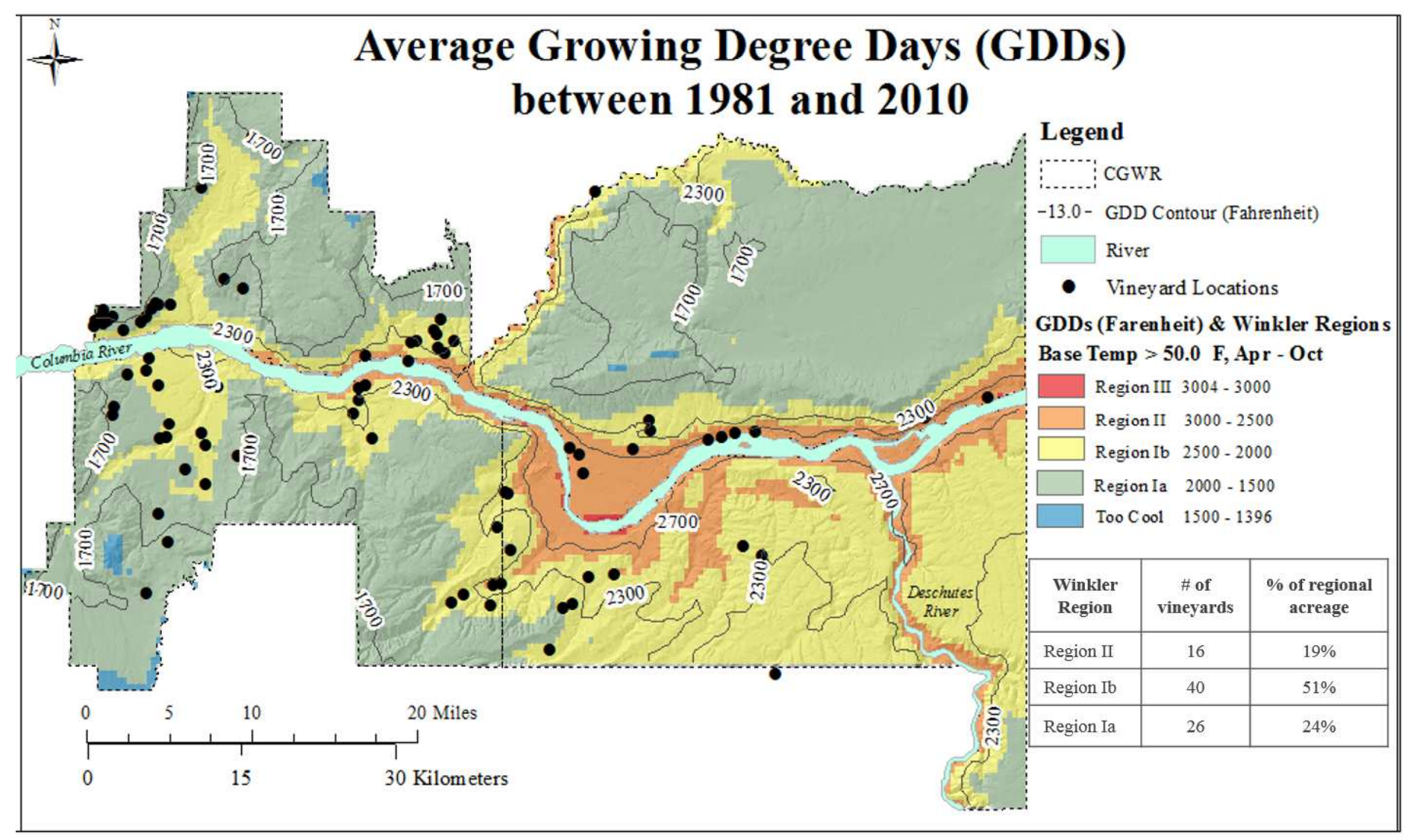

Figure 19. Growing degree-days range from 1396 to 3004 in the CGWR, based on ${ }^{\circ} \mathrm{F}$. Vineyards are located within three Winkler Regions from criteria set by Winkler and Amerine (1994) and updated by Jones (2003). Most vineyards are within Region $\mathrm{Ib}(51 \%)$. The GDD Measurements for each Winkler Region above have been adjusted to reflect GDD values measured at each vineyard and are not the identical to the measurement groupings provided by Jones et al., (2010). For example, 3004 GDD s was the highest GDD value measured among the vineyard sites, however Region III as defined by Jones et al., (2010) includes GDD values ranging from $3000-3500$. 
sixteen vineyards are located in Region II. Vineyards in Region Ib sum to 721 acres (51\%of the total growing acreage), while vineyards in Region II sum to 240 acres (19\% of the total vineyard acreage; Figure 19). Vineyards classed as Region II are located at elevations near Mosier and Lyle, and close to the Columbia River near Dallesport and eastward towards Maryhill. Vineyards within the Columbia Gorge AVA are predominantly classed into Region I, whereas vineyards in the Columbia Valley AVA are evenly split between Region I and Region II (Appendix D-2).

As expected, growing degree days follow a similar pattern east to west as compared to average growing season temperatures. Vineyards in White Salmon, Washington, and upper Underwood Mountain and in the upper Hood River Valley, contain between 880-1000 GDD days. Lower elevation vineyards on Underwood Mountain, in White Salmon and in the higher elevation vineyards of the lower Hood River Valley receive between 1002-1072 GDDs. Vineyards in the higher elevated valleys south of The Dalles, and at higher elevations near Lyle, WA vary between 1127-1183 growing degree-days (GDD). Vineyards at lower elevations in Mosier and west of Lyle are similar in GDDs to closer to the city of The Dalles, Oregon, north of Dallesport and east toward Maryhill (Figure 19). The GDD's increase to greater than 1500 in Dallesport and at the eastern-most vineyards near Maryhill.

\subsection{Geology and soils in the CGWR}

Loess is mapped at 238 hectares (590 acres) or $46.5 \%$ of the growing acreage in the CGWR (Table 3). The dominant geological bedrock (that lies underneath the loess) mapped at vineyards in the region include The Dalles Formation, Quaternary Basalt, 
Columbia River Basalt Group, Missoula Flood deposits, Pliocene Basalt/Basaltic Andesite, Young Surficial deposits and Lahar deposits. Geological totals other than loess in Table 3 signify areas that contain soils not derived in loess.

Two kinds of soil map units are located at vineyard sites within the CGWR, consociation and complex. In an area mapped as consociations, soils are dominated by a single soil taxon and similar soils, whereas areas mapped as complex will contain two or more dissimilar components, such soil taxon's or rock outcrops (Soil Survey Staff, 2012a, b). Out of the 495 hectares (1268 acres), 18 hectares (44 acres), or 3\% of the total vineyard acreage are mapped as complex soil (Appendix D - 1). Further soil totals for the regions are based on consociation totals only.

Thirty soil series are mapped at vineyard sites within the Columbia Gorge Wine Region (Table 4). 178.5 hectares (440.8 acres) or $35 \%$ of the growing acreage in the CGWR is planted on the Walla Walla Series soil. Most vineyards (16 total) are planted on the Chemawa Series, however these 16 vineyards smaller in acreage than vineyards planted on the Walla Walla Series. Over half (53.6\%) of the total growing acreage in the CGWR is planted on the Walla Walla and Chemawa Series. Vineyards are planted on five different soil orders including: Mollisols (58\%), Andisols (18\%), Alfisols (13\%), Entisols (4\%) and Inceptisols (3\%; Table 5).

The soil series represented at vineyards classify into nine particle size classes (Table 6). The soils CGWR are dominantly coarse-silty (35\%), fine loamy (22\%), ashy $(17 \%)$ or coarse loamy $(13 \%)$ textures. Drainage properties described for all the soil series found at vineyard sites vary from well-drained to excessively well-drained. All of 
Table 3. Loess is the dominant geological deposit underlying vineyards in the CGWR. Quaternary basalt on Underwood Mountain and in the Hood River Valley is also a common bedrock at vineyard sites. Vineyards are also commonly underlain by Missoula Flood Deposits (silts, sands and gravels), followed by The Dalles Formation, Columbia River Basalt Group, Young surficial deposits (alluvium, landslides, talus), lahar deposits (in the Hood River Valley) and Pliocene basalt and basaltic andesite.

\begin{tabular}{|c|c|c|c|}
\hline $\begin{array}{l}\text { Dominant Geological } \\
\text { Groupings }\end{array}$ & Age Name & $\begin{array}{c}\% \text { of planted } \\
\text { vineyard acreage }\end{array}$ & Map Source \\
\hline Loess & Quaternary & $46.5 \%$ & Soil Survey Staff, 2012 \\
\hline $\begin{array}{l}\text { Quaternary Basaltic andesite } \\
\text { tephra }\end{array}$ & Quaternary & $19.6 \%$ & $\begin{array}{l}\text { Washington State DNR Staff, 2010; McClaughry et al., } \\
\qquad 2012 \mathrm{~b}\end{array}$ \\
\hline Missoula Flood Deposits & Quaternary & $9.1 \%$ & $\begin{array}{l}\text { Washington State DNR Staff, 2010; Ma et al., 2009; } \\
\text { McClaughry et al., 2012b }\end{array}$ \\
\hline Dalles Formation & Miocene & $8.0 \%$ & Washington State DNR Staff, 2010; Ma et al., 2009 \\
\hline Columbia River Basalt Group & Miocene & $7.5 \%$ & $\begin{array}{l}\text { Washington State DNR Staff, 2010; Ma et al., 2009; } \\
\text { McClaughry et al., 2012b }\end{array}$ \\
\hline Young Surficial Deposits & Quaternary & $3.0 \%$ & $\begin{array}{l}\text { Washington State DNR Staff, 2010; Ma et al., 2009; } \\
\text { McClaughry et al., 2012b }\end{array}$ \\
\hline Pliocene Basalt & Pliocene & $3.0 \%$ & $\begin{array}{l}\text { Washington State DNR Staff, 2010; Ma et al., 2009; } \\
\text { McClaughry et al., 2012b }\end{array}$ \\
\hline Lahar Deposits & Pleistocene & $2.3 \%$ & McClaughry et al., 2012b \\
\hline $\begin{array}{l}\text { Young Basaltic } \\
\text { Andesite/Andesite }\end{array}$ & Quatenary & $0.9 \%$ & McClaughry et al., 2012b \\
\hline
\end{tabular}


Table 4. There are 30 soil series represented at vineyards within the CGWR. The Walla Walla Series and Chemawa Series account for over half (53.6\%) of the growing acreage in the CGWR.

\begin{tabular}{|ccccccc|}
\hline & Soil Series & Soil Subgroup & Hectares & Acres & $\begin{array}{c}\% \text { of } \\
\text { growing } \\
\text { acreage }\end{array}$ & $\begin{array}{c}\text { \# of } \\
\text { vineyards }\end{array}$ \\
\hline 1 & Walla Walla & Typic Haploxerolls & 178.4 & 440.8 & $36.0 \%$ & 8 \\
2 & Chemawa & Humic Vitrixerands & 86.9 & 214.7 & $17.6 \%$ & 16 \\
3 & Chenoweth & Typic Haploxerolls & 24.7 & 61.1 & $5.0 \%$ & 7 \\
4 & Oak Grove & Ultic Haploxeralfs & 24.6 & 60.9 & $5.0 \%$ & 8 \\
5 & Wind River & Typic Haploxerolls & 23.2 & 57.3 & $4.7 \%$ & 5 \\
6 & Cherryhill & Ultic Haploxeralfs & 21.4 & 52.9 & $4.3 \%$ & 8 \\
7 & Hood & Ultic Haploxeralfs & 19.3 & 47.8 & $3.9 \%$ & 6 \\
8 & Fisherhill & Ultic Argixerolls & 14.1 & 35.0 & $2.9 \%$ & 2 \\
9 & Quincy & Xeric Torripsamments & 13.0 & 32.0 & $2.6 \%$ & 2 \\
10 & Underwood & Vitrandic Haploxeralfs & 12.9 & 31.8 & $2.6 \%$ & 7 \\
11 & Wato & Typic Haploxerolls & 9.7 & 24.0 & $2.0 \%$ & 2 \\
12 & Culbertson & Typic Xerumbrepts & 9.5 & 23.6 & $1.9 \%$ & 2 \\
13 & Van Horn & Ultic Argixerolls & 9.2 & 22.8 & $1.9 \%$ & 6 \\
14 & Ewall & Typic Xeropsamments & 8.2 & 20.3 & $1.7 \%$ & 3 \\
15 & Gunn & Ultic Haploxeralfs & 7.2 & 17.9 & $1.5 \%$ & 4 \\
16 & McElroy & Andic Humixerepts & 5.8 & 14.3 & $1.2 \%$ & 3 \\
17 & Dallesport & Typic Haploxerolls & 4.9 & 12.0 & $1.0 \%$ & 5 \\
18 & McGowan & Vitrandic Haploxeralfs & 4.8 & 11.9 & $1.0 \%$ & 1 \\
19 & Parkdale & Umbric Vitrandepts & 3.0 & 7.3 & $0.6 \%$ & 1 \\
20 & Endersby & Cumulic Haploxerolls & 2.7 & 6.6 & $0.5 \%$ & 3 \\
21 & Wamic & Typic Xerochrepts & 2.4 & 5.9 & $0.5 \%$ & 2 \\
22 & Rockford & Ultic Haploxerolls & 2.0 & 5.1 & $0.4 \%$ & 2 \\
23 & Balake & Ultic Argixerolls & 1.8 & 4.4 & $0.4 \%$ & 3 \\
24 & Nansene & Pachic Haploxerolls & 1.3 & 3.2 & $0.3 \%$ & 1 \\
25 & Wyeast & Aeric Fragiaquepts & 1.2 & 2.9 & $0.2 \%$ & 2 \\
26 & Lickskillet & Lithic Haploxerolls & 0.9 & 2.2 & $0.2 \%$ & 2 \\
27 & Bodell & Lithic Haploxerolls & 0.4 & 1.1 & $0.1 \%$ & 1 \\
28 & Anderly & Typic Haploxerolls & 0.4 & 0.9 & $0.1 \%$ & 1 \\
29 & Tygh & Fluvaquentic Haploxerolls & 0.3 & 0.8 & $0.1 \%$ & 4 \\
30 & Horseflat & Lithic Argixerolls & 0.2 & 0.4 & $0.03 \%$ & 1 \\
\hline & & & & & & \\
\hline
\end{tabular}


Table 5. Five soil orders are represented among the vineyard soils in the CGWR (Soil Survey Staff, 2012a, b)

\begin{tabular}{|c|c|c|c|}
\hline Taxonomic Order & \% of growing acreage & Hectares & Acres \\
\hline Mollisols & $58 \%$ & 298 & 735 \\
Andisols & $18 \%$ & 90 & 222 \\
Alfisols & $13 \%$ & 69 & 170 \\
Entisols & $4 \%$ & 21 & 52 \\
Inceptisols & $3 \%$ & 18 & 44 \\
\hline Total Acreage & & 496 & 1224 \\
\hline
\end{tabular}

Table 6. The soils in the CGWR can be classed into 9 particle size classes, with coarse-silty being the dominant texture.

\begin{tabular}{|c|c|c|c|}
\hline Particle Size Class & \% of growing acreage & Hectares & Acres \\
\hline coarse-silty & $35 \%$ & 182 & 449 \\
fine-loamy & $22 \%$ & 112 & 276 \\
ashy & $17 \%$ & 85 & 211 \\
coarse-loamy & $13 \%$ & 65 & 161 \\
fine & $5 \%$ & 25 & 61 \\
sandy & $5 \%$ & 24 & 58 \\
loamy-skeletal & $2 \%$ & 11 & 28 \\
sandy-skeletal & $1 \%$ & 4 & 10 \\
medial & $1 \%$ & 3 & 7 \\
n/a & $1 \%$ & 3 & 7 \\
\hline \multicolumn{2}{|c}{} \\
\hline
\end{tabular}


the soil series are also characterized by a xeric moisture regime, in which the winter months are wet and cool, and the summer months are warm and dry (Soil Survey Staff, 2010). If they soils are separated by relative age (have a Bt-horizon, including Alfisols and Argixerolls) 41\% are "old" and the other (Mollisols, Entisols, Inceptisols) are relatively young (anywhere from 1,000 to 15,000 years old).

\subsection{Soil Sub-Regions}

The CGWR was separated into seven soil sub-regions based on the clustering of 20 common soil series among vineyard sites (Figure 20). These 20 soil series account for $98.7 \%$ of the growing acreage within the CGWR. Fieldwork was performed to provide descriptions of the dominant soil series in the CGWR. Due to time constraints, the field descriptions are limited to 15 soil pits. Lab results ( $\mathrm{pH}$ and wet color) and field notes for the 15 soil pits are located in the Appendix (Appendix D-3). Geology, soil survey trends and soil pits descriptions are further discussed by each sub-region.

\subsubsection{Hood River Sub-Region}

A range of geologic deposits have been mapped within the Hood River Valley. Quaternary alluvial deposits, Missoula Flood and outwash deposits are mapped at vineyard sites close to Hood River and The Columbia River (McClaughry et al., 2012a). Mudflow, alluvial fan deposits and Pleistocene to Pliocene basalt are mapped at vineyards located on western and eastern hill slopes. Geological deposits unique to the Hood River Valley include lahars deposits (Oak Grove and Hood Lahar) mapped underneath vineyards on the western slopes in the central part of the valley. Vineyard soils that formed in volcanic ash and loess are limited to higher elevated vineyards 


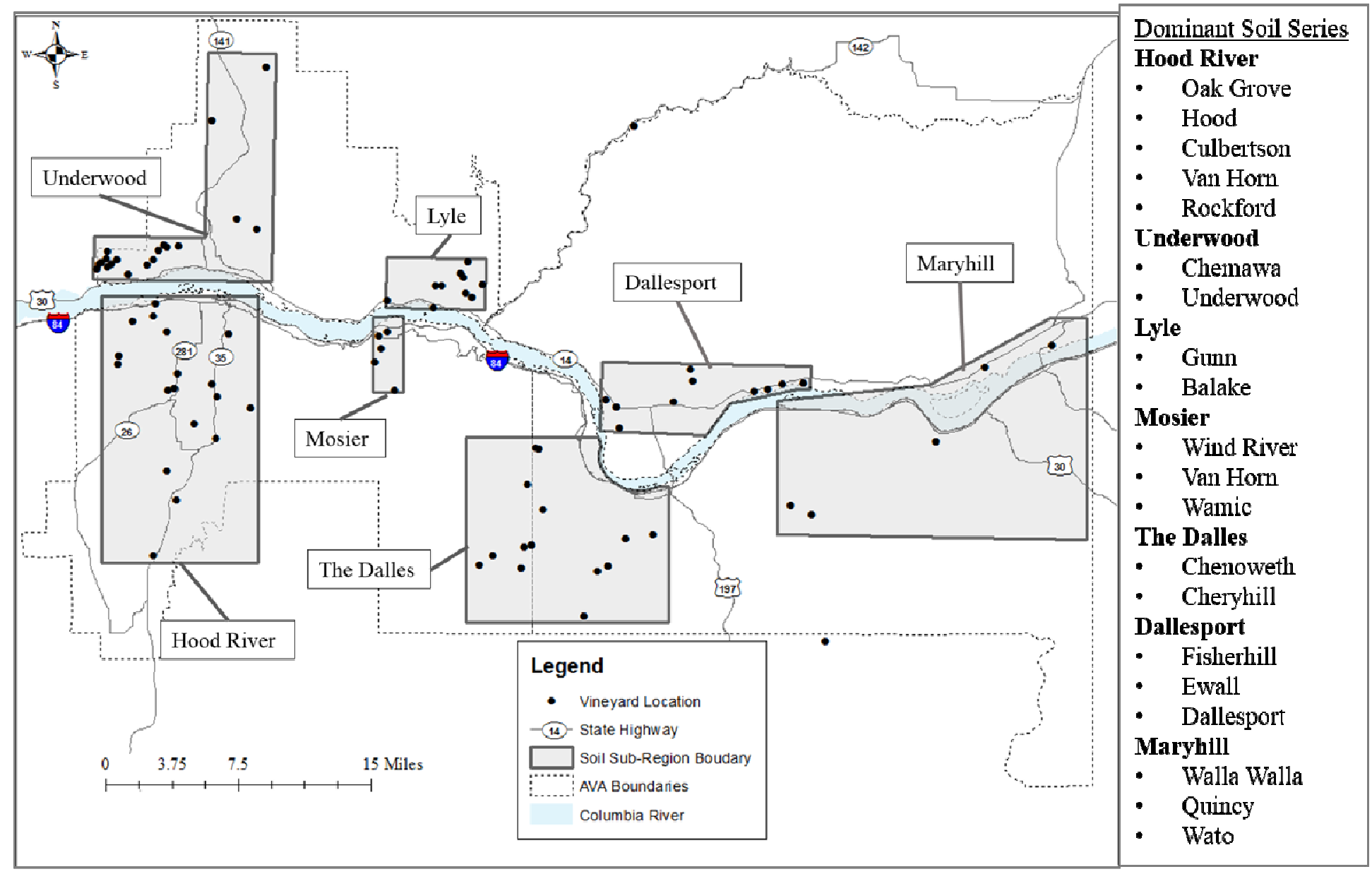

Figure 20. Seven soil regions were drawn based on the clustering of 20 common soil series in the CGWR. The soil sub regions were named by the geographic location within each boundary. These 20 soil series account for $98.7 \%$ of the total growing acreage 
towards the south-east portions of the valley (minimum elevation of 292 and 493 meters).

Vineyard acreage in the Hood River sub-region totals 63.5 hectares (156.8 acres) and 18 separate vineyard sites (Figure 21). The sub-region boundaries were drawn to include vineyards mapped on the Oak Grove, Hood, Culbertson and Rockford soil series (Table 7). The mapped NRCS soil units in this region are dominated by loam textures. Other soil textures are described as sandy fine loam, silt loam, stony loam and variant loam.

Four vineyards were examined and a total of five soil pits were dug to further analyze the soil in the Hood River soil sub-region. All of the soils in this region are consociation except for the rock outcrop Bodell-Bald complex. The Hood River soil subregion is dominated by Ultic Haploxeralfs and Ultic Haploxerolls. Soil characteristics are similar in the field, except the Haploxerolls (Wind River and Rockford Series) have no Bt-horizon.

Marchesi Vineyard was the only vineyard within the Hood River sub-region to have two soil pits. Based on the NRCS soil survey, the two soil series mapped within the vineyard (Van Horn and Rockford) account for seven percent of the growing acreage for this sub-region. The vineyard is located between 186.5 meters (612 feet) and 190 meters (624 feet) elevation. The dominant bedrock is mapped as valley filling outwash gravel and Missoula Flood deposits. Vegetation in the area consists mainly of pasture and hay and native vegetation in non-disturbed areas is mainly ponderosa pine, Douglas fir, Oregon white oak, forbs and shrubs.

The soil pit labeled Marchesi \#1, was dug to a depth of $80 \mathrm{~cm}$ and consists of two 


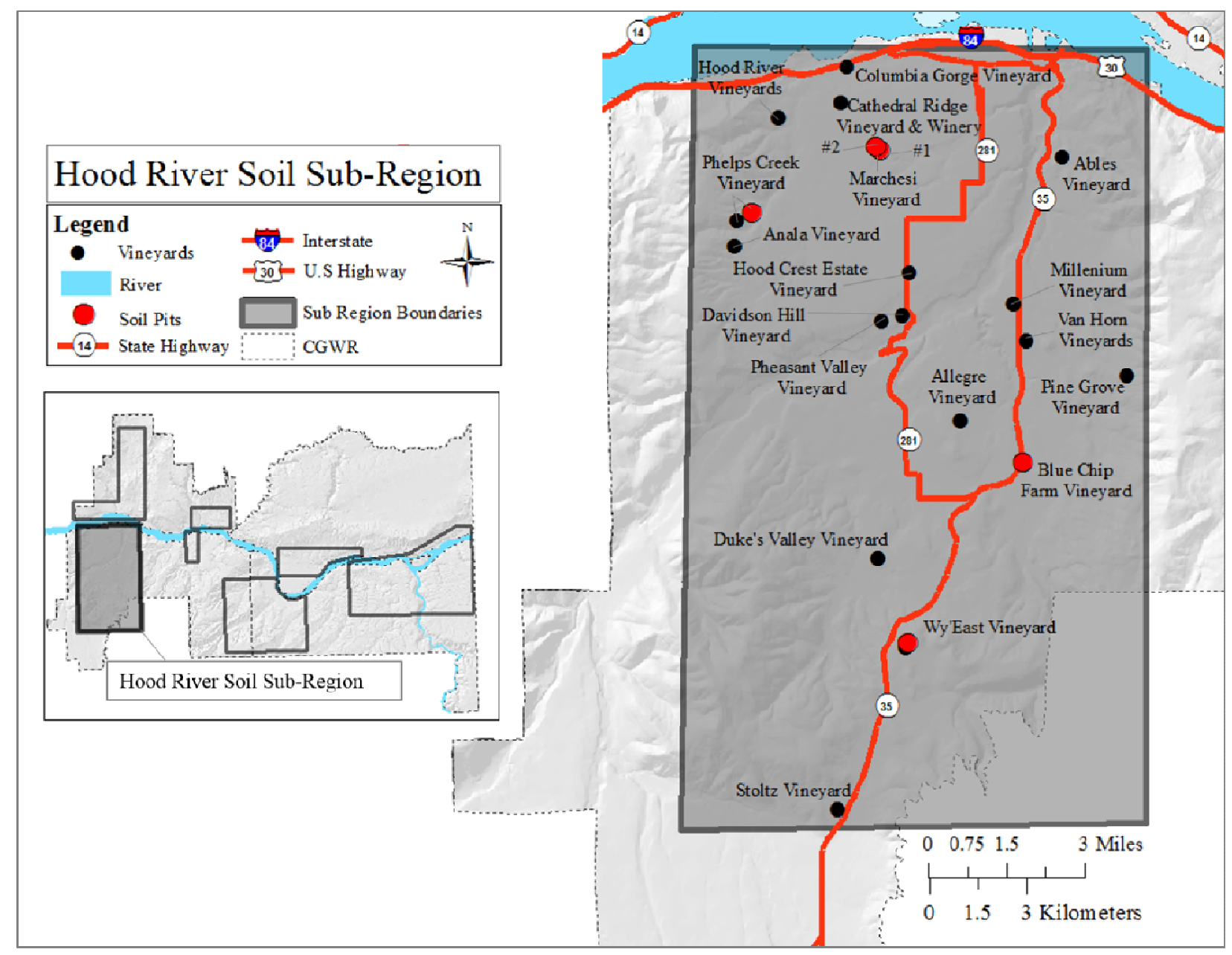

Figure 21. There are 18 vineyards located within the Hood River soil sub-region. Five soil pits were dug in this sub-region: at Phelps Creek Vineyard, Blue Chip Vineyard, Wy'East Vineyard and Marchesi Vineyard to further analyze the common soil 
Table 7. Soil series located among vineyards in the Hood River sub-region. Six soil series were mapped only among vineyards in the Hood River Valley (third column). The Oak Grove and Hood Series are the most commonly planted soil series used to plant grapes in the Hood River sub-region (fourth column).

\begin{tabular}{|c|c|c|c|c|c|c|}
\hline Soil Series & $\begin{array}{l}\text { Subgroup Soil } \\
\text { Name }\end{array}$ & $\begin{array}{l}\text { \% within } \\
\text { sub- } \\
\text { region }\end{array}$ & $\begin{array}{c}\% \text { of total } \\
\text { vineyard } \\
\text { acreage }\end{array}$ & $\begin{array}{c}\text { Number of } \\
\text { vineyards with } \\
\text { soil series }\end{array}$ & $\begin{array}{c}\text { Sub Region } \\
\text { Hectares }\end{array}$ & $\begin{array}{c}\text { Sub Region } \\
\text { Acres }\end{array}$ \\
\hline Oak Grove & Ultic Palexeralf & $100 \%$ & $4.8 \%$ & 8 & 24.6 & 60.9 \\
\hline Hood & Ultic Haploxeralf & $100 \%$ & $3.8 \%$ & 6 & 19.3 & 47.8 \\
\hline Wyeast & Aeric Fragixerand & $100 \%$ & $0.2 \%$ & 2 & 1.2 & 2.9 \\
\hline Rockford & Ultic Haploxeroll & $100 \%$ & $0.4 \%$ & 2 & 2.0 & 5.1 \\
\hline Culbertson & Typic Humixerand & $100 \%$ & $1.9 \%$ & 2 & 9.5 & 23.6 \\
\hline Van Horn & Ultic Argixeroll & $27 \%$ & $0.5 \%$ & 2 & 2.5 & 6.1 \\
\hline Parkdale & Humic Vitrixerand & $100 \%$ & $0.6 \%$ & 1 & 3.0 & 7.3 \\
\hline Wind River & Ultic Haploxeroll & $2 \%$ & $0.1 \%$ & 1 & 0.5 & 1.3 \\
\hline Cumulic Haploxerolls & $\mathrm{n} / \mathrm{a}$ & $100 \%$ & $0.1 \%$ & 1 & 0.6 & 1.4 \\
\hline $\begin{array}{l}\text { Rock outcrop-Bodell-Bald } \\
\text { complex }\end{array}$ & $\mathrm{n} / \mathrm{a}$ & $100 \%$ & $0.03 \%$ & 1 & 0.2 & 0.4 \\
\hline Xerumbrepts & $\mathrm{n} / \mathrm{a}$ & $100 \%$ & $0.01 \%$ & 1 & 0.0 & 0.1 \\
\hline Total & & & & & 63.4 & 156.8 \\
\hline
\end{tabular}


horizons: an A-horizon from 0-30 cm ( $\mathrm{pH} 6.0)$, and a Bw-horizon from 30-80 cm (pH 6.5; Appendix D-3). The Bw-horizon was skeletal, consisting of roughly $40 \%$ gravel ranging in size from cobbles to boulders. Both horizons contained a sandy loam texture. Within the Bw-horizon, a few thin clay films were observed on the ped faces. Field classification of the soil is an Ultic Haploxeroll, and does not match the mapped NRCS classification for the Van Horn Series, which is an Ultic Argixeroll. Although the soil is very similar to the Van Horn Series, this soil pit does not have Bt-horizon needed to have an Argixeroll.

Marchesi \#2 was dug to a depth of $65 \mathrm{~cm}$ and also contained two horizons: an Ahorizon from 0-30 cm, and a Bw-horizon from 30-65+cm (pH 6.3; Appendix D-3). The Bw-horizons also have a sandy loam texture. Field classification is an Ultic Haploxeroll and it matches the mapped NRCS classification for the Rockford Series.

Phelps Creek Vineyard is located at an elevation of 302 meters (992 feet). The dominant geological units mapped at this vineyard include clayey mudflows and Basalt of Post Canyon. The soil pit at this site, dug to a depth of $90 \mathrm{~cm}$ contains two layers: an A-horizon from 0-20 cm ( $\mathrm{pH} 6.0)$, and a Bt-horizon from 20-90 cm (pH 6.0; Appendix D - 3). Soils in both the A and Bt-horizons consist of less than $10 \%$ gravel. Texture for the A-horizon is a sandy loam, while the Bt-horizon has a sandy clay loam texture. Clay films are common and distinct on the ped faces within the Bt-horizon. Field classification of the soil is an Ultic Haploxeralf and was similar to the mapped NRCS classification for the Oak Grove Series.

Blue Chip Vineyard is located at an elevation of 675 feet (206 meters). The 
dominant bedrock is mapped as Missoula Flood sands and silts (McClaughtry et al., 2010). A depth of 60 centimeters was reached, and the pit contains two soil horizons: An A-horizon from 0-16 centimeters ( $\mathrm{pH}$ of 7.2) and a Bt-horizon from 16-60 centimeters ( $\mathrm{pH}$ of 7.2; Appendix D - 3). The texture in the A-horizon is a silt loam while the texture in the Bt-horizon is a silty clay loam. The soil pit is classified as a Typic Haploxeralf in the field. It was very similar to the NRCS classification for the Hood Series, except for a difference $\mathrm{pH}$ values.

Wy'East vineyard lies at elevations between 494 - 527 meters (1,620 - 1,696 feet) and is situated on top of Booth Hill, an extinct Pleistocene volcano. The dominant bedrock at this site is basaltic andesite, volcanic ash and loess. The soil pit at this vineyard was dug to a depth of $80 \mathrm{~cm}$, and it contains two visible horizons: an A horizon from 0-20 cm (pH 6.3), and a Bw-horizon from 20-80 cm (pH 6.6; Error! Reference source not found.). Both the A- and B-horizons all texturally classified as sandy loam. Even though the A-horizon was slightly over-thickened, the soil was classified as Typic Humixerept based on field observations, which is similar to the mapped soil classification for the Culberson Series.

\subsubsection{Underwood Mountain Sub-Region}

Varying ages of basalt (Quaternary to Miocene) overlain by volcanic ash are mapped at vineyards near Underwood, White Salmon and Husum (Figure 22). All the vineyards located on Underwood Mountain, an extinct Boring Lava Volcano, overlay Quaternary basalt and volcanic ash sourced from Underwood Mountain. Young basalt 


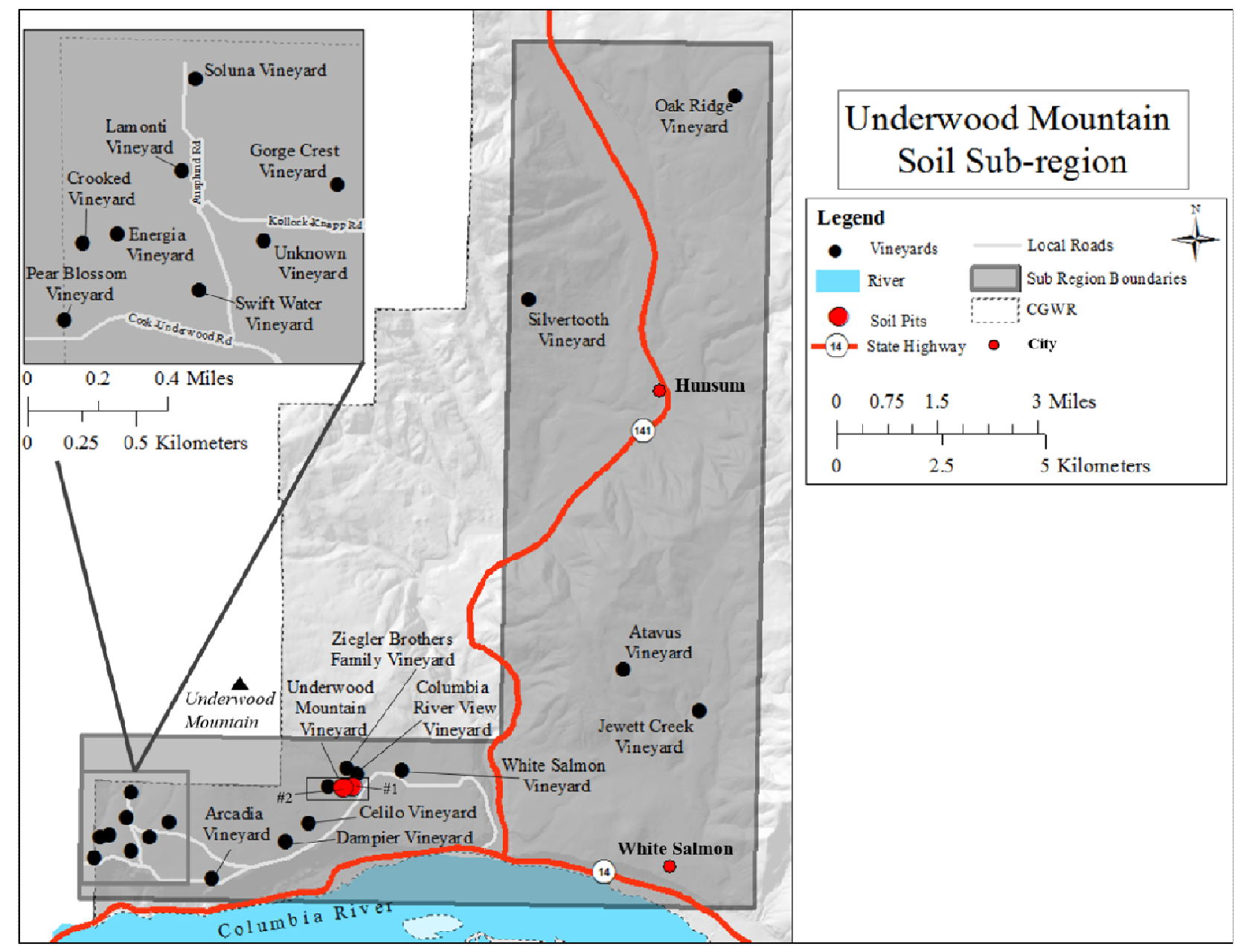

Figure 22. There are 19 vineyards within the Underwood Mountain soil sub-region. Vineyards in this sub-region are dominated by Quaternary volcanic deposits, the Chemawa and Underwood soil series. Soil pits in this sub-region were both located at Underwood Mountain Vineyards 
and andesite colluvium (McCoy Flat Andesite and Gilmer Creek Basalt) is also mapped in the region at vineyards north of Husum and near White Salmon. The Columbia River Basalt Group (Grande Ronde and Frenchman Springs Member) underlies the younger basalt deposits and is exposed at very few vineyards near White Salmon. Andisols soils (Chemawa Series) dominate the region, and all the soils contain vitreous (glassy) or andic (volcanic derived) properties.

The boundaries for the Underwood/White Salmon soil sub region were drawn to include 19 vineyards containing the Chemawa, Underwood (Table 8), McElroy and McGowan soil series. Based on the NRCS Soil Survey, the Chemawa and Underwood Series account for $90 \%$ of the soils mapped in this sub-region. For this study, one vineyard was examined and two soil pits were dug at locations mapped as Chemawa and Underwood Series.

Underwood Mountain Vineyard is located on the eastern slopes of Underwood Mountain, between an elevation of 289 meters (949 feet) to 307 meters (1010 feet). Native vegetation for the Chemawa and Underwood soil series includes Douglas-fir, bigleaf maple, vine maple, starflower, and Western brackenfern. The dominant geological map unit is defined as Underwood Mountain Basalt, mixed with volcanic ash. The first soil pit, labeled Underwood Mountain Vineyard \#1, is located at 289 meters (949 feet) and dug to a depth of $60 \mathrm{~cm}$ (Appendix D-3. The pit contained three horizons: an A1-horizon at 0-16 cm depth, an A2-horizon from 16-29 $\mathrm{cm}$ and a Bt-horizon from 29-60 cm (Appendix D - 3). Two A-horizons have silt loam textures and Bt contained a silt clay loam. The A1-horizon contained mottles, and 
Table 8. Five separate soil series are mapped within the Underwood Mountain soil sub-region. All of the soils in this sub-region are volcanically-derived and contain andic properties (column 2). Majority of the vineyards are planted on the Chemawa Series or the Underwood Series (column 5). The Chemawa Series is the second most common soil series at vineyards in the entire CGWR and is represented among $17 \%$ of the total vineyard acreage (column 4 ).

\begin{tabular}{|c|c|c|c|c|c|c|}
\hline Soil Series & Subgroup Soil Name & $\begin{array}{l}\% \text { within } \\
\text { sub-region }\end{array}$ & $\begin{array}{c}\% \text { of regional } \\
\text { acreage }\end{array}$ & $\begin{array}{l}\text { \# of vineyards in sub } \\
\text { region with soil series }\end{array}$ & $\begin{array}{c}\text { Sub Region } \\
\text { Hectares }\end{array}$ & $\begin{array}{l}\text { Sub Region } \\
\text { Acres }\end{array}$ \\
\hline Chemawa & Humic Vitrixerands & $100 \%$ & $17 \%$ & 16 & 86.9 & 214.7 \\
\hline Underwood & Vitrandic Haploxeralfs & $100 \%$ & $3 \%$ & 7 & 12.9 & 31.8 \\
\hline McElroy & Andic Humixerepts & $100 \%$ & $1 \%$ & 2 & 5.8 & 14.3 \\
\hline McGowan & Vitrandic Haploxeralfs & $100 \%$ & $1 \%$ & 1 & 4.8 & 11.9 \\
\hline Xerorthents & $\mathrm{n} / \mathrm{a}$ & $100 \%$ & $0.02 \%$ & 1 & 0.1 & 0.3 \\
\hline Total & & & & & 110.5 & 273.0 \\
\hline
\end{tabular}


pisolites (iron oxide concretions were common in all layers. The field classification of this soil pit) is Vitrandic Haploxeralf and is in agreement with the NRCS classification for the Underwood Series.

The second soil pit, labeled as Underwood Mountain Vineyard \#2 was dug to a depth of $65 \mathrm{~cm}$, and contained three soil horizons: an A1-horizon from 0-27 cm, an A2horizon from 27-38 cm, and a Bw-horizon from 38-65 cm (Appendix D - 3). This soil is similar Underwood Mountain Vineyard \#1, except it contains a Bw horizon and is less developed. The field classification of the second soil pit, Humic Vitrixerand, is in agreement with the NRCS classification for the Chemawa Series. Both the Chemawa and Underwood Series look similar in the field, but the Underwood is a little more developed and has a Bt-horizon.

\subsubsection{Mosier sub-region}

The geological units mapped at vineyards within the Mosier sub-region are dominated by Quaternary surficial deposits and the Columbia River Basalt. The mapped Quaternary surficial deposits include Missoula flood deposits (fine and coarse), alluvium and loess. Missoula Flood deposits are mapped at every vineyard site in this sub-region. Glacial erratics (granitic boulders) were observed in the field at Saddle View Estate Vineyards. The coarsest Missoula Flood deposits (gravel) are mapped at vineyards closest to the Columbia River. Fine-grained Missoula Flood deposits (silts and sands) are mapped at higher elevation vineyards in the back tributaries of the Mosier Valley.

The Mosier sub-region was drawn to include 5 vineyards that are dominated by the Wamic and Wind River soil series (Table 5). The Van Horn series, mapped at 


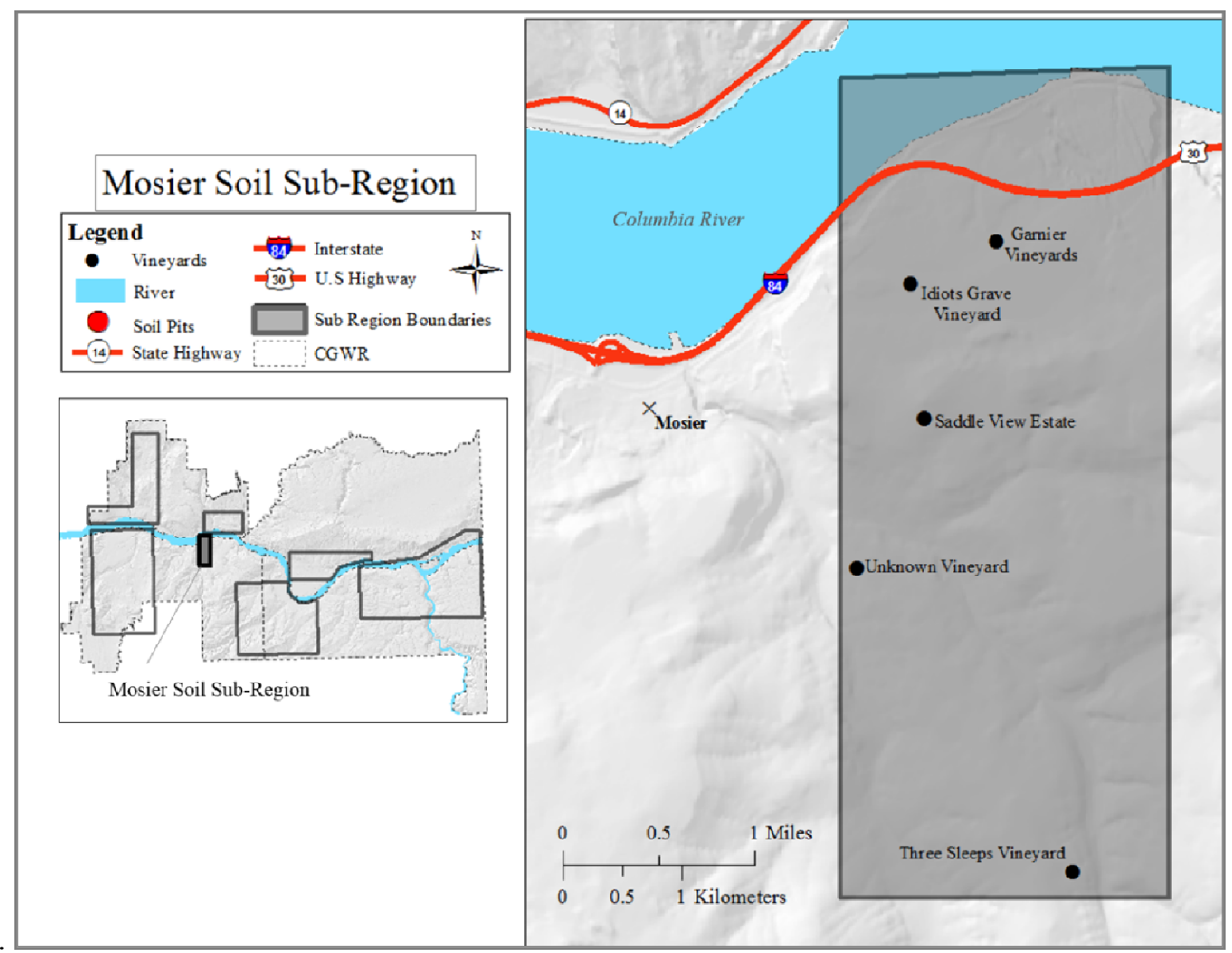

Figure 23. There are 5 vineyards within the Mosier soil sub-region. Due to times constraints, the soil was not further examined among soil pits. Majority of the vineyards in this sub-region are planted on Missoula Flood deposits and loess. This soil subregion was drawn to include vineyard primarily planted on the Wind River and Wamic soil series. 
Table 9. The Wamic soil series is only located at vineyards in the Mosier soil sub-region. The Wind River Series is the most commonly used series for viticulture in the Mosier sub-region (column 5). The Wind Series is also mapped at Columbia Gorge Vineyard near Hood River, Oregon.

\begin{tabular}{|c|c|c|c|c|c|c|}
\hline Soil Series & $\begin{array}{l}\text { Subgroup Soil } \\
\text { Name }\end{array}$ & $\begin{array}{l}\text { \% within } \\
\text { sub- } \\
\text { region }\end{array}$ & $\begin{array}{l}\% \text { of total } \\
\text { vineyard } \\
\text { acreage }\end{array}$ & $\begin{array}{l}\text { Number of } \\
\text { vineyards with } \\
\text { soil series }\end{array}$ & $\begin{array}{c}\text { Sub } \\
\text { Region } \\
\text { Hectares }\end{array}$ & $\begin{array}{l}\text { Sub } \\
\text { Region } \\
\text { Acres }\end{array}$ \\
\hline Wind River & Typic Haploxerolls & $98 \%$ & $4.4 \%$ & 4 & 22.7 & 56.0 \\
\hline Wamic & Typic Xerochrepts & $100 \%$ & $0.8 \%$ & 2 & 4.2 & 10.4 \\
\hline Van Horn & Ultic Argixerolls & $37 \%$ & $0.7 \%$ & 2 & 3.4 & 8.3 \\
\hline $\begin{array}{l}\text { Rock outcrop-Xeropsamments } \\
\text { complex }\end{array}$ & $\mathrm{n} / \mathrm{a}$ & $100 \%$ & $0.3 \%$ & 1 & 1.5 & 3.7 \\
\hline Wamic-Skyline complex & $\mathrm{n} / \mathrm{a}$ & $100 \%$ & $0.4 \%$ & 1 & 1.8 & 4.5 \\
\hline Total & & & & & 33.5 & 79.2 \\
\hline
\end{tabular}


vineyard sites within the Hood River Valley, is also mapped at vineyards in the Mosier Valley. The Van Horn series is more common in the Hood River Valley and is only present at $37 \%$ of the vineyards sub-regional acreage in the Mosier Valley. Soils containing fine sandy loam textures are at sites closest to the Columbia River. Due to time constraints, no vineyard or soil profiles were examined for the Mosier sub-region

\subsubsection{Lyle sub-region}

The geological deposits mapped within the Lyle sub-region include basalt, the Dalles Formation, and Quaternary deposits including loess, alluvium and Missoula Flood deposits. Most vineyards are mapped as containing basalt colluvium mixed with loess. Vineyard soils formed in loess are mapped above 140 meters (459 feet) in elevation. The Dalles Formation and Quaternary basalt (Balch Lake Basalt) and CRB dominate the highest elevation vineyards, while those closest to the Columbia River are dominated by Missoula Flood and alluvium deposits.

The Lyle sub-region has 10 vineyards (22 vineyard blocks) totaling to 33.5 hectares (79.2 acres; Figure 24). The boundaries were drawn to include vineyards mapped on the Balake or Gunn Series (67\% of the regional acreage; Table 10). Other soils contain a mixture of Gunn and Galiente series (complex) or mixed with rock outcrop (Table 10). Two soil pits were analyzed at two separate vineyard sites, including Parkers Vineyard and Cor Cellars Vineyard.

Parkers (Memaloose) vineyard is on a ridge north of Lyle, Washington. Pleistocene-Pliocene aged basalt (basalt of Balch Lake) with a loess cap is mapped at this site. Field observations indicate a very dense, hard layer below 27 inches $(68.5$ 


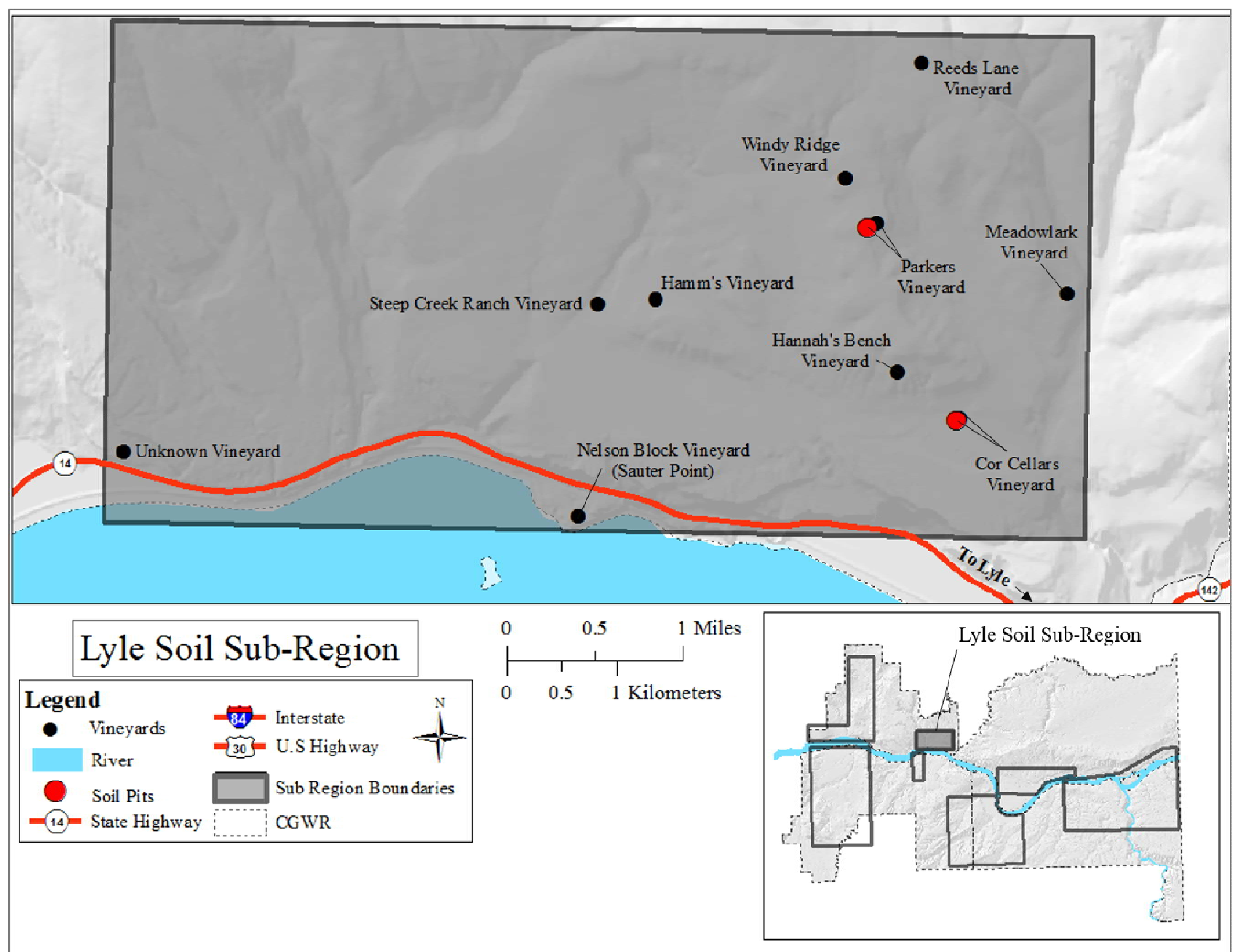

Figure 24. There are ten vineyards located within the Lyle soil sub-region. Two soil pits were dug at Parkers (Memaloose) Vineyard and Cor Cellars Vineyard. 
Table 10. The Balake and Gunn Series are the dominant soil series in the Lyle sub region.

\begin{tabular}{|c|c|c|c|c|c|c|}
\hline Soil Series & $\begin{array}{l}\text { Subgroup Soil } \\
\text { Name }\end{array}$ & $\begin{array}{l}\% \\
\text { within } \\
\text { sub- } \\
\text { region }\end{array}$ & $\begin{array}{c}\% \text { of } \\
\text { total } \\
\text { vineyard } \\
\text { acreage }\end{array}$ & $\begin{array}{c}\text { Number of } \\
\text { vineyards } \\
\text { with soil } \\
\text { series }\end{array}$ & $\begin{array}{c}\text { Sub } \\
\text { Region } \\
\text { Hectares }\end{array}$ & $\begin{array}{c}\text { Sub } \\
\text { Region } \\
\text { Acres }\end{array}$ \\
\hline Balake & Ultic Argixerolls & $100 \%$ & $0.3 \%$ & 4 & 1.8 & 4.4 \\
\hline Gunn & Ultic Haploxeralfs & $44 \%$ & $0.6 \%$ & 3 & 3.2 & 7.9 \\
\hline Gunn-Galiente complex & $\mathrm{n} / \mathrm{a}$ & $100 \%$ & $0.4 \%$ & 4 & 2.0 & 4.9 \\
\hline Rock outcrop-Haploxerolls complex & $\mathrm{n} / \mathrm{a}$ & $31 \%$ & $0.2 \%$ & 6 & 1.1 & 2.8 \\
\hline Rock outcrop-Rubble land-Haploxerolls complex & $\mathrm{n} / \mathrm{a}$ & $15 \%$ & $0.02 \%$ & 2 & 0.1 & 0.2 \\
\hline
\end{tabular}


centimeters), which is likely, weathered basalt bedrock. It was learned from a conversation with the resident that the nearby structure required blasting to construct a shallow foundation. Native vegetation at this site includes ponderosa pine and grasses.

The soil pit at Parkers vineyards was dug to a depth of $70 \mathrm{~cm}$ and contains two soil horizons: an A-horizon from 0-38 cm (pH 6.3), and a Bt-horizon from $38-70 \mathrm{~cm} \mathrm{(pH}$ 6.3; Appendix D - 3). The texture in the A-horizon is a silt loam, and the texture in the Bt-horizon is a silty clay loam. Few to common clay films are present within the Bthorizon. The soil pit is classified as an Ultic Argixeroll, and is very similar texturally to the classification for Gunn Series (Ultic Haploxeralf). The field classification does not match the classification because the A-horizon at this site is thicker than expected, however, below the A-horizon the soil appears to be match the Gunn Series.

Cor Cellars Estate Vineyard, located north of Lyle at the winery site, is surrounded by native vegetation similar to Memaloose vineyard, including scrubby grasslands and Oregon white oak. The dominant geology at this site is mapped as the Dalles Formation and loess. A soil pit was dug at this site to a depth of $19 \mathrm{~cm}$ and contains three horizons: an O-horizon $1 \mathrm{~cm}$ thick, and Ap-horizon at 0-19 $\mathrm{cm}$ depth $(\mathrm{pH}$ 6.1) and a Btj-horizon beginning at $19 \mathrm{~cm}$ ( $\mathrm{pH} 6.5$; Error! Reference source not found.). This soil is cultivated soil (Ap-horizon) with a very skeletal texture at its base. It is very well drained and contains few to faint clay films in the Btj-horizon. The field classification is an Ultic Argixeroll which is similar to the mapped NRCS classification for the Balake Series. 


\subsubsection{Dallesport sub-region}

Missoula Flood gravels and Columbia River Basalt Group (CRBG) and loess dominate the geological deposits within the Dallesport sub-region. The Missoula Flood gravels are mapped at sites below an elevation of 87 meters (285 feet). Above this, variations of the CRBG dominate (Grande Ronde and Wanapum Basalt). All vineyard above an elevation of 250 meters ( 820 feet) are described as forming in loess mixed with basalt or eolian deposits. Silt loam textures dominate the soils at vineyards in this region. Fine sandy loam textures, loamy sand textures, and very cobbly fine sand textures are mapped at lower elevation vineyards (<198 meters;649 feet). The mapped soils range from well-drained to somewhat excessively drained (very cobbly fine sand) and excessively drained (loamy sand).

The Dallesport sub-region contains seven vineyards (51 blocks) totaling to 77 acres (31 hectares; Figure 25). The sub-regional boundaries were drawn to include vineyards dominated by the Fisherhill, Ewall and Dallesport Series (Table 11). For this study, three vineyards were examined, and three soil pits were dug within this region. Chuckar Ridge vineyard is located north of Dallesport, Washington at an elevation of 297 meters (975 feet). The topography is dominated by hillsides and the native vegetation typical of the mapped soil series includes scrubby grassland and Oregon white oak. The soil pit at this site was dug to a depth of $22 \mathrm{~cm}$ and includes two horizons: An A-horizon from 0-13 cm depth (pH 6.9) and a Bt-horizon from 0-22cm (pH 6.8; Appendix D - 3. The texture of the A-horizon is a sandy loam, while the Bt-horizon is a silty clay loam. Prominent clay films are abundant on ped faces in the Bt-horizon. The field classification 


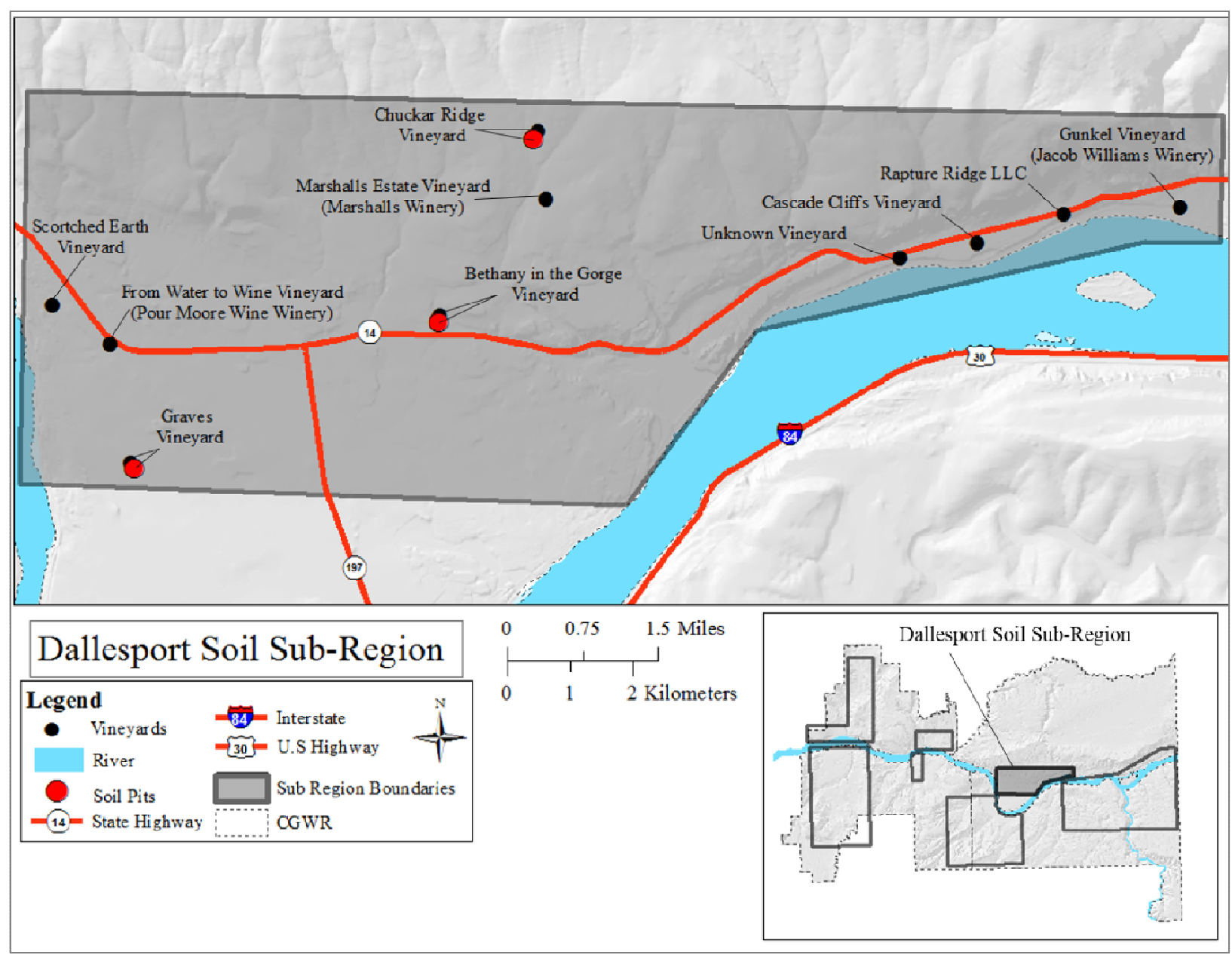

Figure 25. There are 7 vineyards (77 acres) near Dallesport, Washington that are dominated by the Fisherhill, Ewall, and Dallesport Series. The geological deposits vary from Loess at higher elevation vineyards, to Missoula Flood and Sand Dune deposits at lower elevation vineyards. The soil pits were dug at three vineyards in the Dallesport soil sub-region. 
Table 11. The Fisherhill, Dallesport, and Ewall series are mapped only at vineyard sites with the Dallesport soil sub-region. The Walla Walla series, which is dominant in the Maryhill sub-region, is also present in the Dallesport sub-region.

\begin{tabular}{|c|c|c|c|c|c|c|}
\hline Soil Series & Subgroup Soil Name & $\begin{array}{l}\% \\
\text { within } \\
\text { sub- } \\
\text { region }\end{array}$ & $\begin{array}{c}\% \text { of } \\
\text { total } \\
\text { vineyard } \\
\text { acreage }\end{array}$ & $\begin{array}{c}\text { Number of } \\
\text { vineyards } \\
\text { with soil } \\
\text { series }\end{array}$ & $\begin{array}{c}\text { Sub } \\
\text { Region } \\
\text { Hectares }\end{array}$ & $\begin{array}{c}\text { Sub } \\
\text { Region } \\
\text { Acres }\end{array}$ \\
\hline Fisherhill & Ultic Argixerolls & $100 \%$ & $3 \%$ & 2 & 14.1 & 35.0 \\
\hline Dallesport & Typic Haploxerolls & $100 \%$ & $1 \%$ & 4 & 4.9 & 12.0 \\
\hline Walla Walla & Typic Haploxerolls & $6 \%$ & $2 \%$ & 4 & 10.2 & 25.1 \\
\hline Ewall & Typic Xeropsamments & $100 \%$ & $2 \%$ & 3 & 8.2 & 20.3 \\
\hline Rock outcrop-Haploxerolls complex & $\mathrm{n} / \mathrm{a}$ & $63 \%$ & $0.5 \%$ & 2 & 2.3 & 5.7 \\
\hline Dallesport-Rock outcrop complex & $\mathrm{n} / \mathrm{a}$ & $100 \%$ & $0.04 \%$ & 3 & 0.2 & 0.5 \\
\hline Stacker-Horseflat complex & $\mathrm{n} / \mathrm{a}$ & $76 \%$ & $0.4 \%$ & 2 & 1.8 & 4.4 \\
\hline $\begin{array}{l}\text { Rock outcrop-Rubble land-Hapioxerolls } \\
\text { complex }\end{array}$ & $\mathrm{n} / \mathrm{a}$ & $4 \%$ & $0.004 \%$ & 1 & 0.02 & 0.05 \\
\hline Total & & & & & & \\
\hline
\end{tabular}


of a Typic Haploxeralf did not match the sub-group for the mapped Fisherhill Serie s (Ultic Argixeroll) because the A-horizon was not thick enough. Potential soil series reclassification in the Cherryhill Series in Wasco, County.

The Bethany in the Gorge Vineyard is located south of Chuckar Ridge Vineyard at an elevation of 159 meters (520 feet). Natural vegetation typical of the soil series at thesite is described as grasses, shrubs and ponderosa pine. The soil pit dug was dug to a depth of $66 \mathrm{~cm}$ and contains two horizons: an A horizon from 0 to $15 \mathrm{~cm}(\mathrm{pH} \mathrm{7.6)}$ and a Bw horizon from 15 to $66 \mathrm{~cm}(\mathrm{pH} 7.0$; Appendix D-3). The texture of both horizons is classified as a sandy loam in the field. Many cobbles (6 inches; 2.5 centimeters) and few boulders ( 1 foot; 30 centimeters) were encountered throughout the horizons, and the boundaries are disturbed by the cobbles. The NRCS Survey classification of the site is the Dallesport Series (Typic Haploxeroll). The soil pit field field classification is a Typic Haploxerpt, as the A-horizon is not as thick as is described in the mapped unit.

Graves vineyard is one of the oldest vineyards, located at an elevation of 80 meters (262 feet) near Dallesport, Washington. Native vegetation is described as containing bitterbrush, blue bunch wheatgrass and ponderosa pine. The depth of the soil pit at this site was dug to 67 centimeters, containing two horizons: an A-horizon from 0$30 \mathrm{~cm}(\mathrm{pH} 7.5)$ and a C-horizon from 30-67 cm ( $\mathrm{pH} 7.4$; Appendix D-3). The texture throughout the pit is a loamy sand with a very weak structure. The field classification of this pit results in a Typic Xeropssament and matches the NRCS classification of the Ewall Series. 


\subsubsection{The Dalles Sub-region}

Slackwater sediments (sand and silts) from the Missoula Floods are mapped at lower elevation vineyard sites in the Mill Creek Valley and other tributary valleys surrounding The Dalles (below about 221 meters). Vineyard soils formed in loess are mapped on hill slopes away from the Columbia River. Beneath the loess cover that ranges from 20 centimeters to 1 meters in depth and at lower elevation vineyards, common geological deposits include The Dalles Formation, alluvium, CRBG (Wanapum basalt) and landslides deposits (Ma et al., 2009; written commun. Alan Busacca; 2015). The Dalles sub-region includes 13 vineyards, dominated by the Chenoweth and Cherryhill soil series; the Cherryhill series is a residual soil formed by the weathering of (Figure 26; Table 12). Other soil series include Van Horn, Tygh, and Bodell Series. Two soil pits and two separate vineyards were chosen for further analysis.

HD LLC (Hillside Vineyard) is located near a tributary, just south of The Dalles. Native vegetation includes bunch grasses, Oregon white oak and ponderosa pine. The soil pit was located at an elevation of 196 meters (643 feet) and includes three soil horizons: an A-horizon from 0-15 cm ( $\mathrm{pH} 6.9)$, a Bw-horizon from 15-45 cm ( $\mathrm{pH} 7.1)$ and a Bthorizon at $45 \mathrm{~cm}(\mathrm{pH} 7.0$; Appendix D-3). The soil is stiff and contains calcic development in the Btj horizon. Textures ranged from silty loam (A-horizon and Bhorizon) to a silty clay loam (Btj-horizon). This soil was classified as a Typic Haploxerept, which is different than the NRCS mapped series, Chenoweth (Typic Haploxeroll), because the A-horizons not as expected.

Dry Hollow Vineyards in southwest of HD LLC vineyards at an elevation of 303 


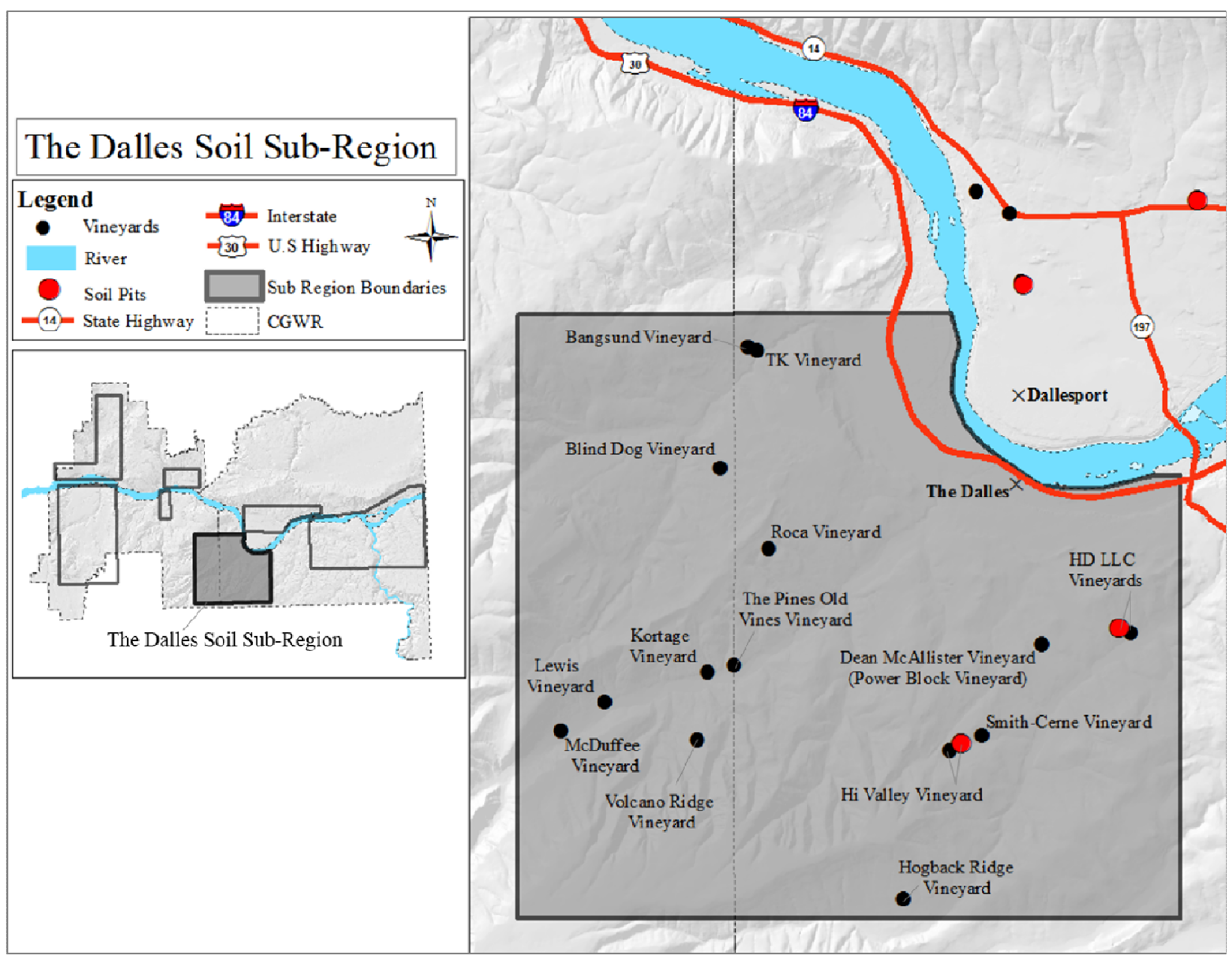

Figure 26. There are 13 vineyards within The Dalles soil sub-region. Vineyards in this region overly the Cherryhill and Chenoweth Series, as well as the Missoula Flood and loess deposits. One soil pit was analyzed at Hi Valley Vineyard and another soil pit was analyzed at HD LLC (Hillside) Vineyards. 
Table 12. There are six soil series and three complex soils within The Dalles soil sub-region. The boundaries for this sub-region were drawn to include sites dominated by the Cherryhill and Chenoweth soil series.

\begin{tabular}{|c|c|c|c|c|c|c|}
\hline Soil Series & Subgroup Soil Name & $\begin{array}{l}\text { \% within } \\
\text { sub- } \\
\text { region }\end{array}$ & $\begin{array}{c}\% \text { of total } \\
\text { vineyard } \\
\text { acreage }\end{array}$ & $\begin{array}{c}\text { Number of } \\
\text { vineyards with } \\
\text { soil series }\end{array}$ & $\begin{array}{c}\text { Sub } \\
\text { Region } \\
\text { Hectares }\end{array}$ & $\begin{array}{c}\text { Sub } \\
\text { Region } \\
\text { Acres }\end{array}$ \\
\hline Cherryhill & Ultic Haploxeralfs & $100 \%$ & $4.2 \%$ & 7 & 21.4 & 52.9 \\
\hline Chenoweth & Typic Haploxerolls & $100 \%$ & $4.8 \%$ & 6 & 24.7 & 61.1 \\
\hline Tygh & Fluvaquentic Haploxerolls & $88 \%$ & $0.1 \%$ & 3 & 0.3 & 0.7 \\
\hline Van Horn & Ultic Argixerolls & $37 \%$ & $0.7 \%$ & 2 & 3.4 & 8.3 \\
\hline Endersby & Cumulic Haploxerolls & $100 \%$ & $0.5 \%$ & 4 & 2.7 & 6.6 \\
\hline Bodell & Lithic Haploxerolls & $100 \%$ & $0.1 \%$ & 1 & 0.4 & 1.1 \\
\hline Hesslan-Skyline complex & $\mathrm{n} / \mathrm{a}$ & $100 \%$ & $0.4 \%$ & 5 & 2.2 & 5.6 \\
\hline $\begin{array}{l}\text { Cherryhill-Rock outcrop } \\
\text { complex }\end{array}$ & $\mathrm{n} / \mathrm{a}$ & $100 \%$ & $0.4 \%$ & 1 & 1.8 & 4.6 \\
\hline Skyline-Hesslan complex & $\mathrm{n} / \mathrm{a}$ & $100 \%$ & $0.02 \%$ & 3 & 0.1 & 0.3 \\
\hline Total & & & & & 57.1 & 141.0 \\
\hline
\end{tabular}


meters (994 feet). The soil pit was dug to a depth of $22 \mathrm{~cm}$, and two soil horizons were observed: an A-horizon from 0-10.5 cm (pH 6.2) and a Bk-horizon from 10.5 to $22 \mathrm{~cm}$ (pH 6.5; Appendix D-3). The soil contains a hardpan (calcic horizon) at a very shallow depth, making it difficult to dig further. The A-horizon was a sandy loam and the Bkhorizon was a sandy clay. The soil classification, named as a Petrocalcic Calcixerpet in the field, did not match the NRCS Classification for the Cherryhill Series (UlticArgixeralf).

A soil series description taken by Alan Busacca at Volcano Ridge Vineyard provides a common soil description of the Cherryhill Series. This soil pit was dug to a depth of 70 centimeters and four soil horizons were observed (Appendix D-17). The Cherryhill Series commonly contains sandy loam textures near the surface and sandy clay loam textures in the argillic (Bt) horizon (written communication, Alan Busacca, 2015).

\subsubsection{Maryhill sub-region}

Alluvium, Missoula Flood deposits, and loess are common geological deposits at vineyard sites in the Maryhill sub-region. Vineyards in this region are planted on Columbia River Basalt benches that are overlain with Missoula Flood and loess deposits. Other vineyards including Sunshine Mountain and Emerson Loop Vineyard are planted on hillsides, southeast of The Dalles, Oregon. These sites are dominated by loess-derived soils.

The Maryhill sub-region was drawn to include vineyards dominated by the Walla Walla, Quincy and Wato Series (Table 13). There are five vineyards within this subregion totaling to 189 hectares (513 acres; Figure 27). Due to time constraints, one 


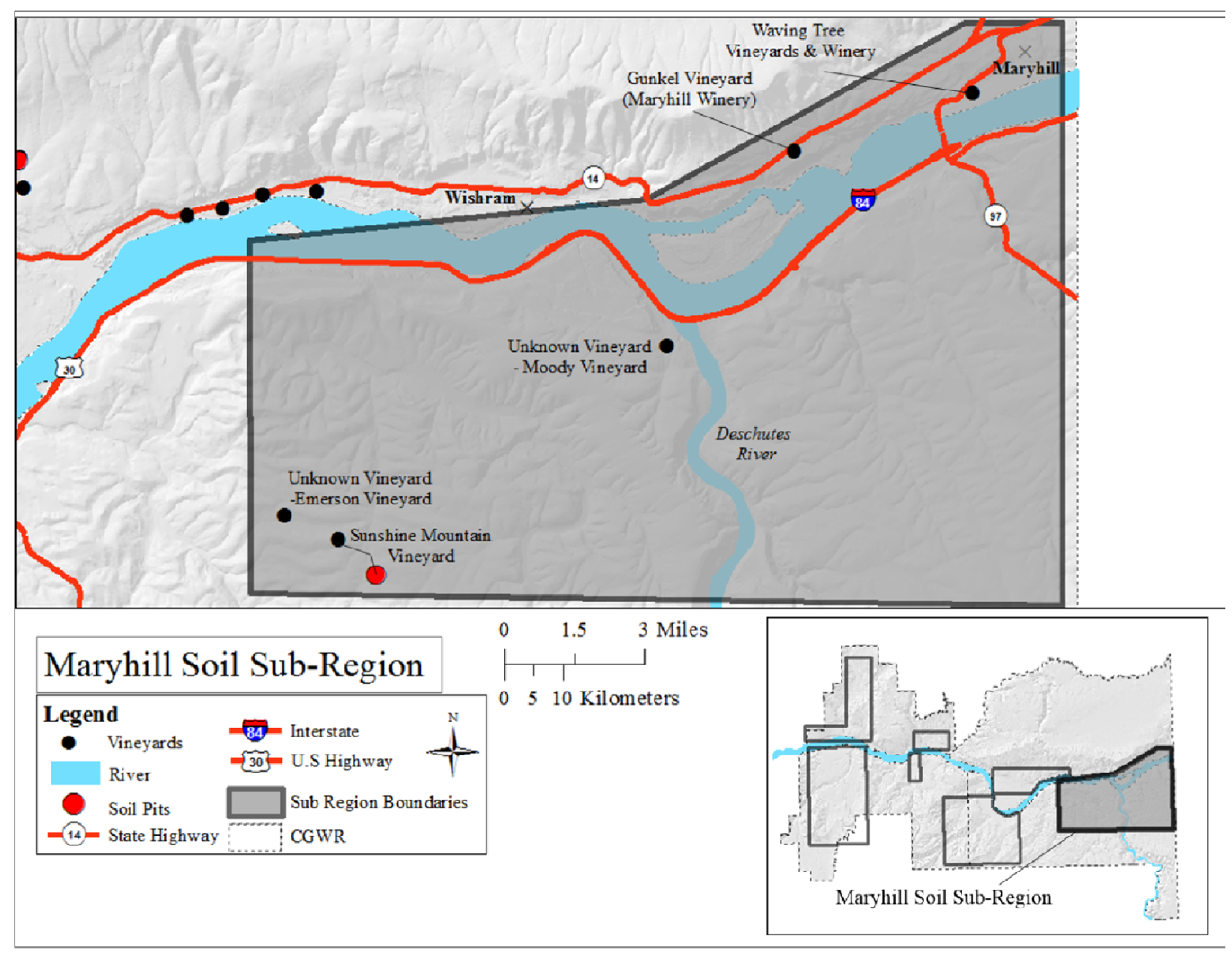

Figure 27. There are five vineyards (totaling to 189 hectares; 513 acres) within the Maryhill sub-region. Vineyards in this region are dominated by Loess, the Walla Walla series and the Quincy Series. Sites close to the Columbia River contain skeletal and sandy textures and derived from alluvium and Missoula Flood deposits. Silt loam textures are common of sites derived in loess. 
Table 13. The Walla Walla, Quincy, Wato, Nansene and Anderly soil series dominate in the Maryhill sub-region.

\begin{tabular}{|c|c|c|c|c|c|c|}
\hline Soil Series & Subgroup Soil Name & $\begin{array}{l}\% \\
\text { within } \\
\text { sub- } \\
\text { region }\end{array}$ & $\begin{array}{l}\% \text { of } \\
\text { total } \\
\text { vineyard } \\
\text { acreage }\end{array}$ & $\begin{array}{l}\text { Number of } \\
\text { vineyards } \\
\text { with soil } \\
\text { series }\end{array}$ & $\begin{array}{l}\text { Sub } \\
\text { Region } \\
\text { Hectares }\end{array}$ & $\begin{array}{l}\text { Sub } \\
\text { Region } \\
\text { Acres }\end{array}$ \\
\hline Walla Walla & Pachic Haploxerolls & $91 \%$ & $32 \%$ & 3 & 162 & 400 \\
\hline Quincy & Xeric Torripsamments & $100 \%$ & $3 \%$ & 3 & 13 & 32 \\
\hline Wato & Typic Haploxerolls & $100 \%$ & $2 \%$ & 2 & 9.7 & 24 \\
\hline Nansene & Xeric Torripsamments & $100 \%$ & $0.3 \%$ & 1 & 1.3 & 3 \\
\hline Anderly & Typic Haploxerolls & $100 \%$ & $0.1 \%$ & 1 & 0.4 & 1 \\
\hline Lickskillet & Typic Haploxerolls & $43 \%$ & $0.1 \%$ & 1 & 0.4 & 1 \\
\hline Stacker-Swalecreek-Horseflat complex & Typic Haploxerolls & $100 \%$ & $0.2 \%$ & 2 & 1.0 & 3 \\
\hline Horseflat & Xeric Torripsamments & $100 \%$ & $0.03 \%$ & 1 & 0.2 & 0.4 \\
\hline $\begin{array}{l}\text { Rock outcrop-Rubble land-Haploxerolls } \\
\text { complex } \\
\text { Rock outcrop-Rubble land-Haploxerolls }\end{array}$ & Xeric Torripsamments & $81 \%$ & $0.1 \%$ & 2 & 0.4 & 1 \\
\hline complex & Xeric Torripsamments & $81 \%$ & $0.1 \%$ & 1 & 0.4 & 1 \\
\hline Quincy-Rock outcrop complex & Typic Haploxerolls & $73 \%$ & $0.04 \%$ & 1 & 0.2 & 1 \\
\hline Stacker-Horseflat complex & Xeric Torripsamments & $2 \%$ & $0.01 \%$ & 2 & 0.04 & 0.1 \\
\hline Total & & & & & 189 & 513 \\
\hline
\end{tabular}


vineyard site was examined and contained one soil pit for the Walla Walla Series was examined at Sunshine Mountain Vineyard (elevation of 282 meters; 926 feet).

The soil series (Walla Walla series) mapped at Sunshine Mountain Vineyard represents $86 \%$ of the soils represented at vineyards within this sub-region, therefore a soil pit was necessary. Native vegetation includes blue bunch wheatgrass, sandberg bluegrass, and big sagebrush. A road cut exposing the soil to a depth of $200 \mathrm{~cm}$ wasused.to analyze the soil and contains three horizons: An A-horizon, a Bw-horizon to a depth of 20-90cm (pH 5.9), and a Bk-horizon at 90-200cm (pH 7.2; Appendix D-18). Silt loam textures are constant throughout all the horizons. The soil survey classification of Walla Walla Series (Typic Haploxeroll) did not match the field classification (CalcicHaploxerolls). A reclassification of the Chard Series is recommended, as it contains a Bk horizon overlain by a Bw-horizon. 


\section{CHAPTER 5: DISCUSSION}

\subsection{Geological Influences on Soil Development and Textures}

Soil textures described among the 15 soil pits tend to be coarser and less developed (Bw-Horizons) at sites closest to the Columbia River. It is assumed that areas inundated by the Missoula Floods will have younger soils and more skeletal textures relative to soils not affected by the flooding. To further analyze the effect of the Missoula Floods on vineyard soils, the elevation of maximum flood stage features compiled by Benito and O'Connor (2003) were imported into GIS, and elevation contours were formed for the features recorded at the highest elevations within the CGWR (Figure 5;). There is flaw in relying on current topographic maps to draw the boundaries of the Missoula Flood influences, as the topography has likely changed since the last stage of the Missoula Flood waters 15,000 calendar years ago (Allen et al., 2009). There is also uncertainty in the flood elevation estimations provided by Benito and O'Connor (2003), as many of the elevations were determined by plotting flood features on 1:24,000 topographic maps with uncertainties of about one contour interval (roughly 12 meters) (Benito and O'Connor, 2003). The boundaries of the Missoula Flood extent presented in this paper are not meant to be used to determine the exact boundaries of the Missoula Floods but rather to provide a general sense where differences in soil texture are expected among vineyard sites.

All soils containing gravel are located lower than the estimated flood elevations provided by Benito and O'Connor (2003), suggesting that the Missoula Floods have a direct influence on the texture and age of the soil at these vineyard sites (Figure 28). 


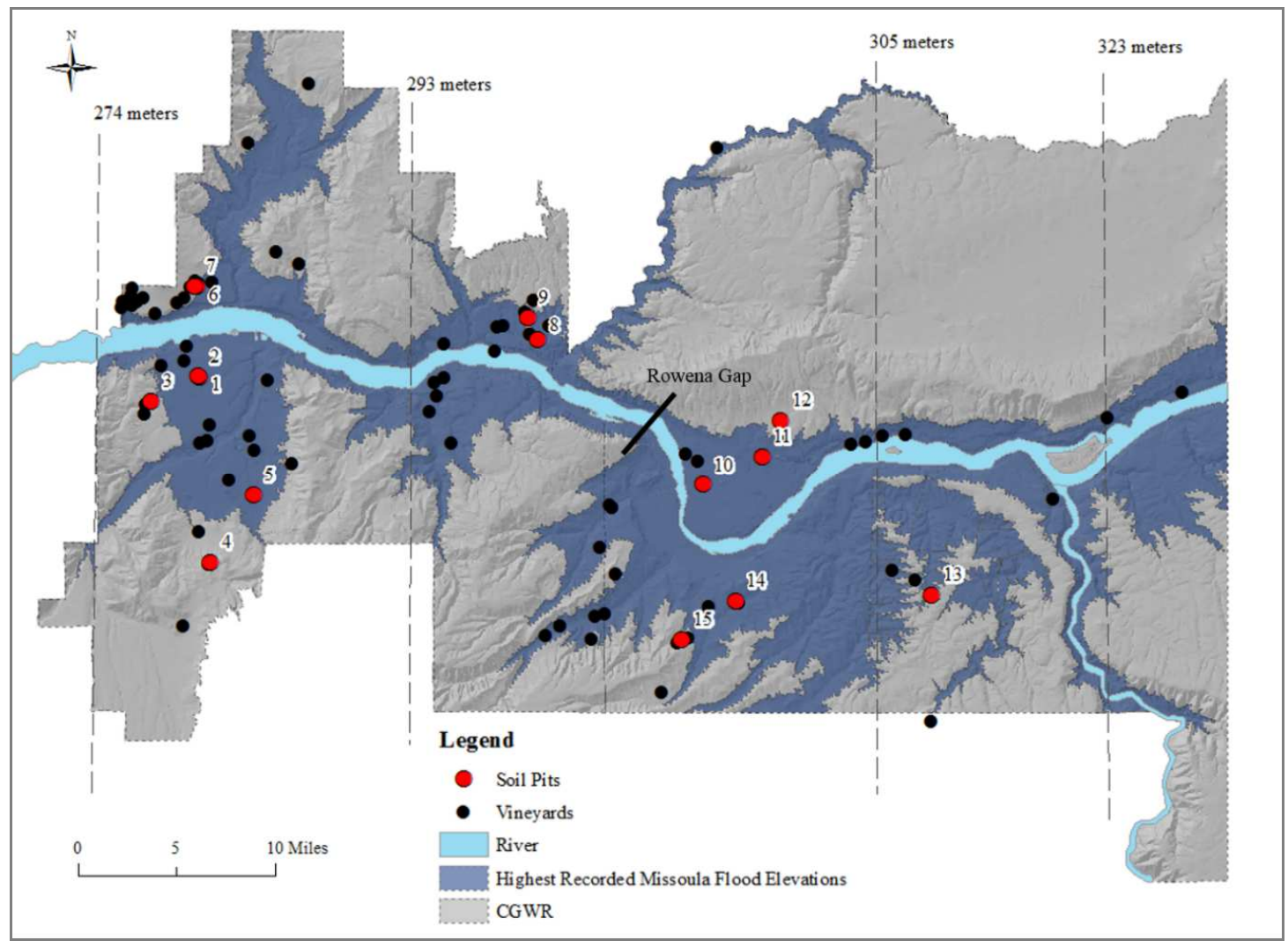

Figure 28. The extent of the Missoula Floods is estimated using maximum flood elevation provided by Benito and O'Connor (2003).All soil pits containing a skeletal texture are below evidence for maximum flood elevations. Soil pit identifications are as the following: 1-Marchesi \#1, 2-Marchesi \#2, 3-Phelps Creek, 4-Wy’East, 5-Blue Chip, 6-Underwood Mt. \#1, 7-Underwood Mt. \#2, 8- Cor Cellars, 9-Parkers (Memaloose), 10-Graves, 11-Bethany in the Gorge, 12-Chuckar Ridge, 13-Sunshine Mt, 14-HD LLC, 15-Dry Hollow. 
Soil pits located at Hillside Vineyard, Sunshine Mountain Vineyard and Blue Chip Vineyard are also below the expected flood elevations however skeletal textures and Bwhorizons do not reside at these sites (Figure 29). These soils might be in areas where flood velocities were slower, leading to finer textures and less erosion (slackwater deposits). For example, the soil pits dug at Hillside Vineyard and Sunshine Mountain Vineyard likely formed in slack-water deposits that were deposited as the flood velocities slowed down by the confinement Rowena Gap just east of the site (Allen et al., 2009; Benito and O'Connor, 2003).

Finer textures (silt-clay loams) and $\mathrm{Bw}, \mathrm{Bk}$ and $\mathrm{Bt}$ horizons were all described at soil pit locations above the estimated flood elevation contours (Figure 28). Other geological influences affect the soils above the reaches of the Missoula Floods waters (Figure 29). The fine-grained Alfisols characterized at Phelps Creek Vineyard are mapped as overlying mud flow deposits in the Hood River Valley (Figure 29; Appendix D-3). Soil pits developed in loess near Lyle, Washington and The Dalles, Oregon contain silty textures with $\mathrm{Bt}$ and Bk horizons (Figure 29; Appendix D-3). Soils containing both $\mathrm{Bt}$ and Bw-horizons are also found in soil pits on overlying Underwood Mountain basalt and on Post Canyon Basalt deposits (Appendix D-3). Other geological and pedalogical factors may cause similar soil textures and development to what is expected below the uppermost Missoula Flood elevations, and 


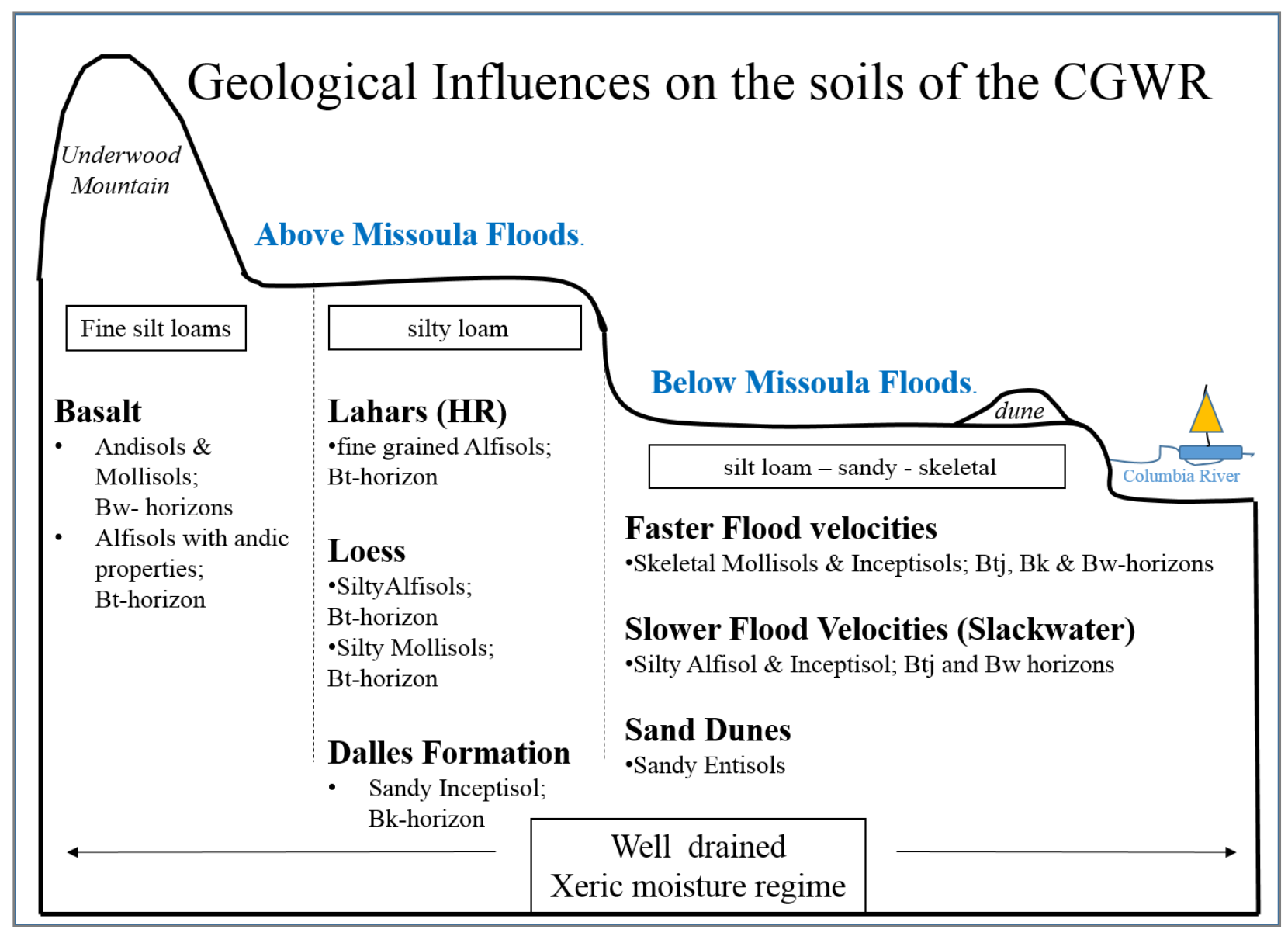

Figure 29. Soil texture and development characterized at each soil pit varies above and below the expected Missoula Flood elevations. All the sites containing skeletal textures are below expected Missoula Flood elevations. Above the expected Missoula Flood elevations, geological deposits influencing the soil include lahars, loess, The Dalles Formation and Basalt. 
therefore, further site specific work is needed to analyze soil textures at vineyards that border the flood feature elevations.

\subsection{Comparisons of climatic totals}

Some common wine regions with similar growing degree days to those within Columbia Gorge Wine Region include Burgundy, France, The Willamette Valley, The Bordeaux Region of France and The Umpqua Valley AVA in southern Oregon (Jones 2011; Table 2). Areas similar to Burgundy, France within the Columbia Gorge Wine Region include majority of the Columbia Gorge AVA, and higher elevation vineyards near Lyle, Mosier, The Dalles and Dallesport. Vineyards at relatively low elevations near Mosier, Lyle, The Dalles, Dallesport, and east of Wishram experience similar growing degree day temperatures to those measured in Bordeaux, France and The Umpqua Valley AVA in southern Oregon.

Comparing mean, minimum and maximum GST values to grapevine climatematurity groupings Jones, (2010) shows a diverse range of suitable grape varieties within the CGWR (Figure 30). The diverse range in grape variety plantings within the CGWR is expected to be partially reflective of experimentation performed by vintners and also the diversity of macro-climates within the CGWR. Current grape variety plantings analyzed for each climatic regime within the CGWR suggests that the diversity in grape variety plantings is indeed reflective of the climate. Majority of the grapes (82\%) planted within the cool-climatic regime are varieties defined by Jones (2010) to be typical of a cool climate region $\left(13-15^{\circ} \mathrm{C}\right.$; Figure 30; Table 14). Exceptions include warm varietals (Semillon, Viognier, Nebbiolo, and Sangiovese) planted at Hood River Winery Estate. 


\section{Grapevine Climate/Maturity Groupings}

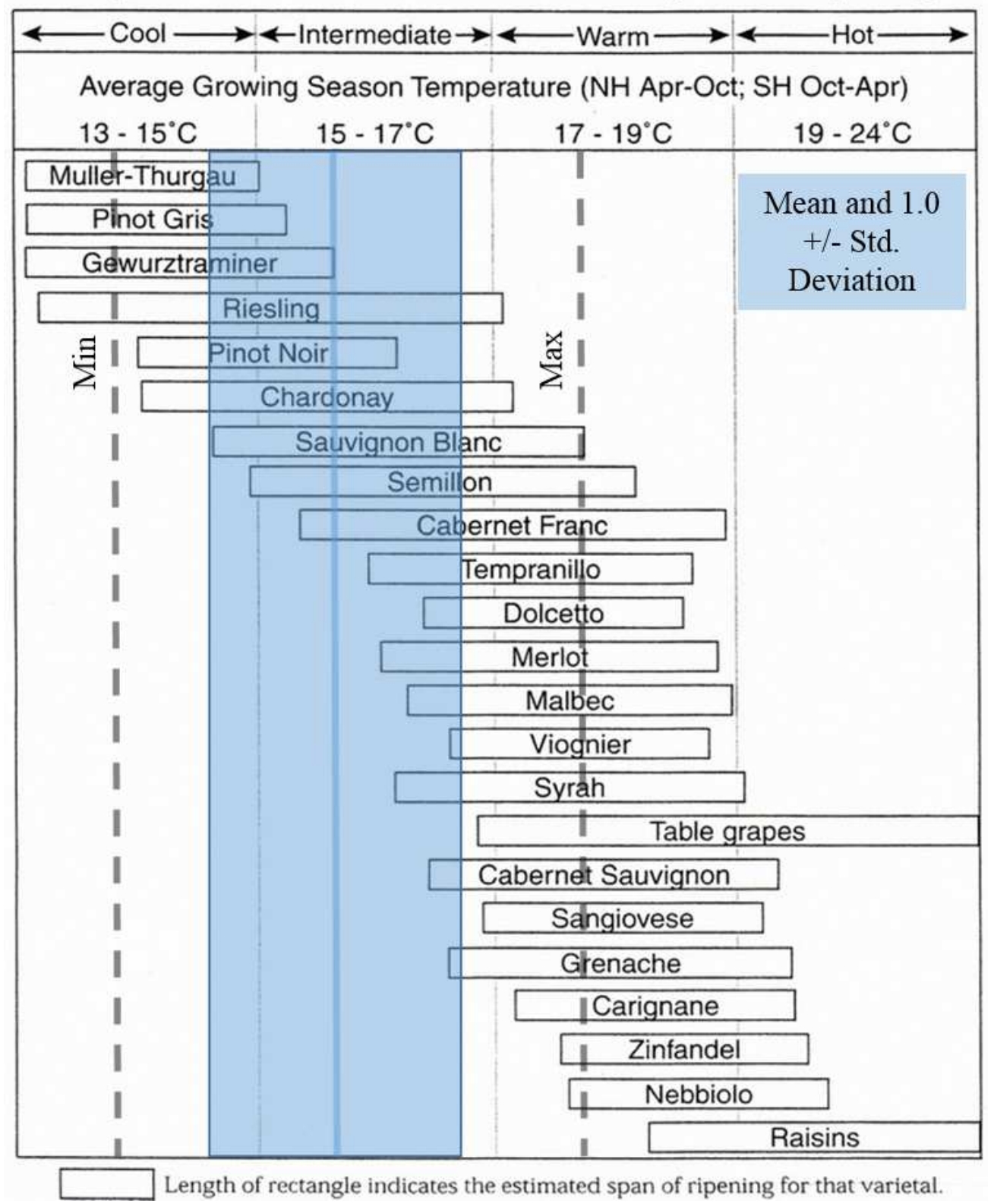

Figure 30.Climate maturity groupings based upon average growing season temperatures (Jones et al., 2002b). The vertical dark blue bar is the mean value for the CGWR, while the shaded area is the predominant climate suitability in the region $(+/-1.0$ standard deviation about the mean). 
Table 14. Grapes of the cool climate regime of the CGWR. The typical regime that each variety falls within is provided by Jones, $2010.82 \%$ of the grapes planted within the cool-climates regimes of the CGWR are typical cool-climate (or early ripening) varieties. $6 \%$ of the varieties planted within the cool-climatic regime are typical of regions of intermediate or warmer. $12 \%$ of the region contained varieties in which Jones, 2010 did not characterize a typical regime.

\begin{tabular}{|c|c|c|c|c|c|}
\hline Regime & $\begin{array}{c}\text { Current Grape Varieties } \\
\text { Planted }\end{array}$ & $\begin{array}{c}\text { Typical Growing } \\
\text { Regime } \\
\text { (Jones, 2010) } \\
\end{array}$ & $\begin{array}{l}\% \text { of growing } \\
\text { acreage }\end{array}$ & Acreage & $\begin{array}{c}\text { \# of } \\
\text { vineyards }\end{array}$ \\
\hline \multirow{16}{*}{$\begin{array}{c}\text { Cool-Climate } \\
\text { Regime of } \\
\text { CGWR }\end{array}$} & Pinot Noir & \multirow{7}{*}{$\begin{array}{c}\text { Cool } \\
\left(13-15^{\circ} \mathrm{C}\right)\end{array}$} & $31 \%$ & $92.1 *$ & 17 \\
\hline & Gewurztraminer & & $17 \%$ & $51.5^{*}$ & 9 \\
\hline & Chardonnay & & $14 \%$ & $43.1 *$ & 9 \\
\hline & Pinot Gris & & $13 \%$ & $38.5^{*}$ & 12 \\
\hline & Riesling & & $7 \%$ & $22.0^{*}$ & 8 \\
\hline & Sauvignon Blanc & & $0 \%$ & 1.3 & 1 \\
\hline & Muller Thurgau & & $0 \%$ & 0.5 & 1 \\
\hline & Tempranillo & \multirow{8}{*}{$\begin{array}{l}\text { Intermediate- } \\
\text { Warm-Hot } \\
\left(15-19^{\circ} \mathrm{C}\right)\end{array}$} & $2 \%$ & $6^{*}$ & 3 \\
\hline & Dolcetto & & $2 \%$ & $4.6^{*}$ & 3 \\
\hline & Syrah & & $1 \%$ & $4.1 *$ & 3 \\
\hline & Merlot & & $1 \%$ & $3.5^{*}$ & 3 \\
\hline & Sangiovese & & na & na* & 1 \\
\hline & Nebbiolo & & na & na* & 1 \\
\hline & Viognier & & na & na* & 1 \\
\hline & Semillon & & na & na* & 1 \\
\hline & * The acreage estimat & $\begin{array}{r}\text { or these varieti } \\
\text { under }\end{array}$ & $\begin{array}{l}\text { not provided } \\
\text { ed (Table 18). }\end{array}$ & neyar & erefore \\
\hline
\end{tabular}


Underwood Mountain and in the Hood River Valley (Table 14).

$51 \%$ of the grapes planted within the Intermediate climatic regime in the CGWR are varieties typical of the intermediate climatic zone (Table 15). Exceptions include warm region varietals (Zinfandel, Viognier, and Sangiovese) planted in regions average GST values of $16^{\circ} \mathrm{C}$. Pinot Noir is also planted in the intermediate region with GSTs greater than $16.5^{\circ} \mathrm{C}$, which is typically a high GST value for Pinot Noir. Of the grape varieties provided by Greg Jones (2010), only the warm region varieties are planted within the warm climatic regime of the CGWR (Table 16).

Out of all the 41 grape varieties planted, Pinot Noir is the dominant grape in terms of number of vineyard plantings and also by acreage estimates. Pinot Noir is planted among the largest range of GST temperatures, ranging from $13.8^{\circ} \mathrm{C}$ to $16.3^{\circ} \mathrm{C}$. Even taking out the 53 hectare (130 acre) planting of Pinot Noir at the region's largest vineyard site from the total estimation, Pinot Noir is still the most widely planted grape variety in the region, totaling to 67 hectares (166 acres) among 33 vineyard sites; the second highest planting is Syrah grapes, which totals to 35 hectares ( 87 acres) at 31 vineyards. It is possible that economic reasons override the terroir conditions when making decisions about grape variety plantings in the CGWR. The "jammy" Pinot Noir grown in warmer regions is desirable by winemakers in the Willamette Valley who aim at mixing with their, especially in colder years (verbal communication, Lonnie Wright, 2013). 
Table 15. Grapes of the Intermediate Climate Regime of the CGWR. 51\% of the grape varieties planted within the Intermediate climatic zone are typical of an intermediate climatic region, characterized by Jones, $2010.7 \%$ of the grapes are typical of a warm climatic region and $42 \%$ are grapes typical for a cool climatic regime

\begin{tabular}{|c|c|c|c|c|c|}
\hline Regime & $\begin{array}{c}\text { Typical Climatic } \\
\text { Regime }\end{array}$ & Grape Variety & $\begin{array}{l}\% \text { of growing } \\
\text { acreage within } \\
\text { regime }\end{array}$ & $\begin{array}{l}\text { Estimated } \\
\text { Acreage }\end{array}$ & $\begin{array}{c}\text { \# of } \\
\text { vineyard } \\
\text { plantings }\end{array}$ \\
\hline \multirow{17}{*}{$\begin{array}{c}\text { Intermediate } \\
\text { Regime of } \\
\text { CGWR }\end{array}$} & \multirow{3}{*}{$\begin{array}{r}\text { Cool } \\
\left(13-15^{\circ} \mathrm{C}\right)\end{array}$} & Pinot Noir & $41 \%$ & 204.3 & 17 \\
\hline & & Gewurztraminer & $1 \%$ & 2.7 & 3 \\
\hline & & Muller Thurgau & $0.01 \%$ & 0.1 & 1 \\
\hline & \multirow{13}{*}{$\begin{array}{l}\text { Intermediate } \\
\left(15-17^{\circ} \mathrm{C}\right)\end{array}$} & Syrah & $12 \%$ & 58.4 & 21 \\
\hline & & Merlot & $7 \%$ & 35.3 & 9 \\
\hline & & Chardonnay & $6 \%$ & 29.7 & 8 \\
\hline & & Pinot Gris & $6 \%$ & 27.4 & 7 \\
\hline & & Cabernet Sauvignon & $4 \%$ & 21.8 & 8 \\
\hline & & Riesling & $4 \%$ & 18.5 & 10 \\
\hline & & Tempranillo & $2 \%$ & 11.2 & 6 \\
\hline & & Sauvignon Blanc & $2 \%$ & 9.9 & 6 \\
\hline & & Grenache & $2 \%$ & 9.4 & 8 \\
\hline & & Viognier & $2 \%$ & 8.2 & 10 \\
\hline & & Malbec & $1 \%$ & 3.0 & 3 \\
\hline & & Sangiovese & $0.4 \%$ & 2.1 & 3 \\
\hline & & Dolcetto & $0.4 \%$ & 2.0 & 2 \\
\hline & $\begin{array}{l}\text { Warm } \\
\left(15-17^{\circ}\right)\end{array}$ & Zinfandel & $7 \%$ & 32.6 & 4 \\
\hline & $*$ The acreage & $\begin{array}{l}\text { lations for these va } \\
\text { are therefore ur }\end{array}$ & $\begin{array}{l}\text { ties were not } \mathrm{pr} \\
\text { restimated }(\mathrm{Ta}\end{array}$ & $\begin{array}{l}\text { ded for ever } \\
18) \text {. }\end{array}$ & neyard and \\
\hline
\end{tabular}


Table 16. Grapes of the warm-climatic regime of the CGWR. Of the grapes characterized by Jones et al. (2010), only warm varietals are present in the warm climatic regime, compromising $87 \%$ of the total acreage.

\begin{tabular}{|c|c|c|c|c|c|}
\hline $\begin{array}{l}\text { Climatic } \\
\text { Regime }\end{array}$ & $\begin{array}{c}\text { Typical Climatic } \\
\text { Regime }\end{array}$ & Grape Varieties & $\begin{array}{l}\% \text { of growing acreage } \\
\text { within regime }\end{array}$ & $\begin{array}{l}\text { Estimated } \\
\text { Acreage }\end{array}$ & $\begin{array}{c}\text { \# of vineyard } \\
\text { plantings }\end{array}$ \\
\hline $\begin{array}{l}\text { Warm- } \\
\text { Climatic } \\
\text { Regime of } \\
\text { CGWR }\end{array}$ & Warm & $\begin{array}{c}\text { Zinfandel } \\
\text { Syrah } \\
\text { Nebbiolo } \\
\text { Merlot } \\
\text { Sangiovese } \\
\text { Malbec } \\
\text { Grenache } \\
\text { Cabernet Sauvignon } \\
\text { Cabernet Franc } \\
\text { Dolcetto } \\
\text { Sauvignon Blanc } \\
\text { Viognier }\end{array}$ & $\begin{array}{l}24 \% \\
21 \% \\
10 \% \\
8 \% \\
7 \% \\
6 \% \\
5 \% \\
3 \% \\
2 \% \\
1 \% \\
\mathrm{n} / \mathrm{a} \\
\mathrm{n} / \mathrm{a}\end{array}$ & $\begin{array}{c}24.6^{*} \\
21.75^{*} \\
9.8 \\
8.25^{*} \\
7.0^{*} \\
5.9^{*} \\
5.0^{*} \\
3.2^{*} \\
2.0^{*} \\
1.5 \\
\mathrm{n} / \mathrm{a} \\
\mathrm{n} / \mathrm{a}\end{array}$ & $\begin{array}{l}6 \\
6 \\
3 \\
3 \\
2 \\
4 \\
2 \\
1 \\
2 \\
2 \\
1 \\
1\end{array}$ \\
\hline & Theosmonos & $\begin{array}{l}\text { nations for these vari } \\
\text { therefore und }\end{array}$ & $\begin{array}{l}\text { ies were not provided } \\
\text { restimated (Table } 18)\end{array}$ & r. & and are \\
\hline
\end{tabular}




\subsection{Evaluation of the Current AVA Boundaries}

As shown before, the Columbia Gorge AVA boundaries were established to include areas distinctive in terroir conditions relative to the Columbia Valley AVA, however, the current AVA boundaries do not reflect the terroir as defined by the conditions among current vineyard sites. This is most apparent at the Pines 1982 vineyard, where the vineyard boundaries are split by the current AVA boundaries (Figure 12). Multiple sub-AVAs can be suggested for the region based one or multiple unique terroir conditions.

One such region includes Underwood Mountain, in which all vineyards are planted on Underwood Mountain Basalt, within a cool climatic regime and are predominantly planted on either the Chemawa or Underwood soil series. Another region may be designated around Mosier and Lyle, in which vineyards are predominantly overlying Missoula Flood sediments and loess and are within an intermediate climatic zone. The soils pits dug near The Dalles, Oregon contain calcium carbonate (Bk-horizon) in both soil pits. Commonalities in the terroir condition at vineyards near The Dalles, Oregon may be the intermediate -warm climate and the presence of calcium carbonate in the soils. More field work is necessary to better define the extent of calcium carbonate. Vineyards east of Dallesport, Washington are dominated by warm growing season temperature, warm to hot grape varieties, Missoula Flood deposits and loess overlying Columbia River Basalt. These terroir conditions are similar to the commonly found at vineyards in the Columbia Valley AVA (Meinert and Bussacca, 2000, 2002). 


\subsection{Geological and Climatic Influences on Irrigation Practices}

Irrigation practices at each of the vineyard sites correlate with the decrease in rainfall in the eastern portions of the wine region (Figure 16). The soil and geologic conditions may also influence irrigation practices in the CGWR. For example, at Allegre Vineyards in the Hood River Valley, specific rows of vineyard require more irrigation that other vines in the same block (verbal communication, Jen Allegre, 2013). Although this vineyard is near other vineyard that practice dry-land farming, the specific site conditions requires the need for irrigation during the growing season. Majority of the vineyards that don't irrigate and use dry-land farming practices are located in areas greater than 60 centimeters (24 inches) of annual rainfall.

\subsection{Data accuracy}

Certain elements of these data are not to be taken for granted. Every time that a shapefile is converted into a raster or a raster file is reclassified, some of the detail is lost. The soil maps, although created to a scale of $1: 24,000$, have contacts that are estimated during the map creation process, and therefore boundaries are not exact. Therefore, it may be possible that a site's soil conditions will vary from what is mapped by the Soil Survey. Soil descriptions in this study showed that condition may vary from what was mapped by the Soil Survey. Except for the soil pit at Hi Valley Vineyard (Error! Reference source not found.), most of the reclassifications are based on differences in the A-horizon depth, A-horizon color, or $\mathrm{pH}$, and it is likely that the reclassified soil is similar to that mapped by the NRCS Soil Survey. However, any land owner referring to these maps should have a soil scientist visit the site and create a more detailed map before 
basing decisions for a vineyard site based on soil types. The geological maps used for this study are not as detailed as would be preferred when investigating a vineyard. Again, field work is recommended to accurately compare of the geology to the soil pits.

The data obtained for elevation and slope for each vineyard are based on a calculated average. The majority pixel value in each vineyard determines the outcome for aspect, curvature, soil and bedrock type; visual reference and field work is needed to verify the results. For example, at Sunshine Mountain vineyard, where the vineyards are located on convex hill-tops, the majority pixel value for aspect may be to one direction, but the vineyards actually face all four aspects. Average growing season temperatures and growing degree days for each vineyard are derived using 400 meter PRISM grids and will likely deviate slightly from measurements at stations located in the CGWR.

Growing degree days (GGD)'s are usually calculated from daily and hourly temperature data, and therefore assumptions had to be made in order to calculate GDDs from monthly PRISM raster data. One GDD value is calculated for each month using monthly maximum and minimum PRISM temperature raster data. This value does not represent the amount of GDD's for each month, but rather represents the average number of hours each day in that month that the temperature was above a base temperature of $10^{\circ} \mathrm{C}\left(50^{\circ} \mathrm{F}\right)$. For example, if the average monthly temperature in April is $13^{\circ} \mathrm{C}\left(55.4^{\circ} \mathrm{F}\right)$, the resulting GDD value would be 3 (the amount of degrees greater than $10^{\circ} \mathrm{C}$ ). In order to determine the number of GDDs for each month, this value was multiplied by the number of days in each month (Table 17). Using the example above, the amount of GDDs calculated for April would become 90. This is performed for every month, leading 
to the summation of hours during the growing season that is comparable to other station data and wine region.

A comparison of synthetic monthly and daily temperature data was compiled in Excel to determine the differences in calculating GDDs from monthly data to daily data. It was determined that if the daily average temperature dropped below $10^{\circ} \mathrm{C}$, then the GDD values calculated using monthly temperature data and did not match GDDs calculated by daily temperature data. In fact, GDD values calculated from the monthly estimations tended to be lower than GDD values calculated by the daily measurements when values were less than $10^{\circ} \mathrm{C}$. It is likely that, especially in the coldest years between 1981-2010, daily temperatures dropped below a base temperature of $10^{\circ} \mathrm{C}\left(50^{\circ} \mathrm{F}\right)$ during the growing season (Jones et al., 2010). It is therefore assumed that the GDDs calculated using monthly PRISM data are lower than what is calculated on a yearly basis using daily temperature data.

Field temperature data provided by Alan Busacca further suggests that GDDS modeled using the PRISM monthly temperature is lower than what is currently being measured at the sites with daily temperature data. GDDs measured at vineyards in the CGWR from 2005 to 2012 were at least 200 GDDs higher than the modeled GDDs provided in this study (Written communication, Alan Busacaa, 2015). GDDs collected from 2009 to 2014 at Washington State University. AgWeatherNet stations are also warmer than the modeled PRISM GDD values (Washington State University Staff, 1988). Therefore, further work collecting field temperature data should be performed at each vineyard for more accurate GDD estimations. Although there is variance in the 
GDD calculations, it is likely that the climate boundaries established using the Winkler Index will not greatly vary.

It is expected that the dominant grape variety totals and the number of planted in the region are underestimated in this study. Dominant grape variety totals are based on the acreage estimations provided by the vintners and also based on the number of vineyards that contained each variety. Estimations were not provided for 12 of the 83 vineyards in this study, leading to the 80 hectares (199.8 acres) or $15 \%$ of the total vineyard acreage to not be represented (Table 18). The grape varieties for three sites were found by interviewing tasting room employees or by online websites or articles. These variety estimates are considered in the number of vineyard planting totals, but not in the acreage estimation totals. The number of vineyard plantings estimates therefore provide a better estimation of what is planted in the CGWR as of 2013. Background information on seven sites was not attained because contact information could not be found for the owners or managers. Therefore, there is a possibility than more grape varieties may be planted within the region that what was found during this study. 
Table 17. The equations used in the Statistics calculator to calculate growing degree days in GIS are provided below. To determine GDDs from a monthly dataset, GDD values had to be multiplied by the average days in each month (bold). This resulted in a value that was similar to GDDs each month, but will vary from GDD values calculated from hourly temperature data.

To calculate GDD -100, accounting for \#days in each month (Cx10)

$\left(\left(\left(\operatorname{Con}\left(\left(\left(" \operatorname{tmin} \_8110 \_04 "+\right.\right.\right.\right.\right.\right.$ "tmax_8110_04") / 2) - 100) > 0,1,0)) * (("tmin_8110_04" + "tmax_8110_04") / 2) - 100)) * 30) +

$(((\operatorname{Con}((($ (tmin_8110_05" + "tmax_8110_05") / 2) - 100) > 0,1,0)) * (("tmin_8110_05" + "tmax_8110_05") / 2) - 100) $) * 31)+$

$(((\operatorname{Con}((($ (tmin_8110_06" + "tmax_8110_06") / 2) - 100) >0,1,0)) * (("tmin_8110_06" + "tmax_8110_06") / 2) - 100) $) * 30)+$

$\left(\left(\left(C o n\left(\left(\left(\left(" t m i n \_8110 \_07 "+" \operatorname{tmax} \_8110 \_07 "\right) / 2\right)-100\right)>0,1,0\right)\right) *\left(\left(\left(" t m i n \_8110 \_07 "+\right.\right.\right.\right.\right.$ "tmax_8110_07") / 2) - 100)) *31) +

$\left(\left(\left(C o n\left(\left(\left(" t \operatorname{tmin} 88110 \_08 "+\right.\right.\right.\right.\right.\right.$ "tmax_8110_08") / 2) - 100) >0,1,0)) * (("tmin_8110_08" + "tmax_8110_08") / 2) - 100) $)$ * 31) +

$(((\operatorname{Con}((($ (tmin_8110_09" + "tmax_8110_09") / 2) - 100) > 0,1,0)) * (("tmin_8110_09" + "tmax_8110_09") / 2) - 100) $) * 30)+$

$\left(\left(\left(C o n\left(\left(\left(\left(" t m i n \_8110 \_10 "+"\right.\right.\right.\right.\right.\right.\right.$ tmax_8110_10") / 2) - 100) >0,1,0)) * ((("tmin_8110_10" + "tmax_8110_10") / 2) - 100)) * 31)

To calculate GDD in Fahrenheit

$\left(\left(\operatorname{Con}\left(\left(\left(\left(\left(" \operatorname{tmin} \_8110 \_04 "+\right.\right.\right.\right.\right.\right.\right.$ "tmax_8110_04") / 2) * 1.8) + 320) - 500) > 0,1,0)) * ((((("tmin_8110_04" + "tmax_8110_04") / 2) * 1.8) + 320)

$-500) * 30))+\left(\left(\operatorname{Con}\left(\left(\left(\left(() \operatorname{tmin} \_8110 \_05 "+\right.\right.\right.\right.\right.\right.$ "tmax_8110_05") / 2) * 1.8) + 320) - 500) > 0,1,0)) * ((((()"tmin_8110_05" + "tmax_8110_05") /

$2) * 1.8)+320)-500) * 31))+\left(\left(\operatorname{Con}\left(\left(\left(\left(\left(" \operatorname{tmin} \_8110 \_06 "+" \operatorname{tmax} \_8110 \_06 "\right) / 2\right) * 1.8\right)+320\right)-500\right)>0,1,0\right)\right) *\left(\left(\left(\left(\left(" \operatorname{tmin} \_8110 \_06 "+\right.\right.\right.\right.\right.$

"tmax_8110_06") / 2)*1.8) + 320) - 500)*30)) +((Con((((("tmin_8110_07" + "tmax_8110_07") / 2) *1.8) + 320) - 500)>0,1,0)) *

$\left.\left.\left(\left(\left(\left(\left(" t \operatorname{tmin} \_8110 \_07 "+" \operatorname{tmax} \_8110 \_07 "\right) / 2\right) * 1.8\right)+320\right)-500\right) * 31\right)\right)+\left(\left(\operatorname{Con}\left(\left(\left(\left(\left(\left(" \operatorname{tmin} \_8110 \_08 "+\right.\right.\right.\right.\right.\right.\right.\right.$ "tmax_8110_08") / 2) * 1.8) + 320) -

$500)>0,1,0)) *\left(\left(\left(\left(\left(" \operatorname{tmin} \_8110 \_08 "+\right.\right.\right.\right.\right.$ "tmax_8110_08") / 2) * 1.8) + 320) - 500) * 31)) +((Con((((()"tmin_8110_09" + "tmax_8110_09") / 2)

$* 1.8)+320)-500)>0,1,0)) *\left(\left(\left(\left(\left(" t \operatorname{tmin} 88110 \_09 "+\right.\right.\right.\right.\right.$ "tmax_8110_09") / 2) * 1.8) + 320) - 500) *30)) +((Con $\left(\left(\left(\left(\left(" \operatorname{tmin} \_8110 \_10 "+\right.\right.\right.\right.\right.$

"tmax_8110_10") / 2) *1.8) + 320) - 500)>0,1,0)) *((((("tmin_8110_10" + "tmax_8110_10") / 2) *1.8) + 320) - 500) *31)) 
Table 18. There are 13 vineyards in which grape variety estimations were not provided. The vineyards labeled "unknown" were sites in which no background information was attained. Expected grape varieties were collected from either online vineyard profiles, winery websites, or communication with owners (Hood River Vineyards \& Winery).

\begin{tabular}{|c|c|c|c|}
\hline $\begin{array}{l}\text { Vineyards not included in } \\
\text { Grape Acreage Estimates }\end{array}$ & Nearest Town & $\begin{array}{c}\text { GIS } \\
\text { Acreage }\end{array}$ & Expected Grape Varieties \\
\hline Annala Vineyard & Underwood Mountain & 8.8 & $\begin{array}{l}\text { Chardonnay, Gewürztraminer, } \\
\text { Gruner Veltliner, Pinot Blanc, } \\
\text { Pinot Gris, Pinot Noir, } \\
\text { Riesling, Syrah, Tempranillo }\end{array}$ \\
\hline Arcadia Vineyard & Maryhill & 24 & $\begin{array}{c}\text { Barbera, Cabernet Franc, } \\
\text { Cabernet Sauvignon, } \\
\text { Grenache, Malbec, Merlot, } \\
\text { Sangiovese, Sauvignon Blanc, } \\
\text { Syrah, Viognier, Zinfandel } \\
\end{array}$ \\
\hline $\begin{array}{c}\text { Gunkell Vineyard (Maryhill } \\
\text { Site) }\end{array}$ & Hood River & 76.4 & $\begin{array}{l}\text { Chardonnay, Dolcetto, } \\
\text { Gewurztraminer, Merlot, } \\
\text { Muscat, Nebbiolo, Pinot Noir, } \\
\text { Riesling, Sangiovese, } \\
\text { Semillon, Viognier }\end{array}$ \\
\hline $\begin{array}{l}\text { Hood River Vineyards \& } \\
\text { Winery }\end{array}$ & Underwood Mountain & 12.1 & - \\
\hline $\begin{array}{l}\text { Soluna Vineyard (Not yet } \\
\text { planted) }\end{array}$ & Mosier & 8.5 & Syrah, Viognier,Tempranillo \\
\hline Three Sleeps Vineyard & Mosier & 6.5 & - \\
\hline $\begin{array}{c}\text { Unknown Vineyard- CG } \\
\text { Mosier }\end{array}$ & The Dalles & 3.1 & - \\
\hline $\begin{array}{l}\text { Underwood Vineyard- } \\
\text { Deere Run Farm and } \\
\text { Vineyard }\end{array}$ & The Dalles & 16.7 & - \\
\hline $\begin{array}{c}\text { Unknown Vineyard- } \\
\text { Emerson Loop Vineyard }\end{array}$ & The Dalles & 41.9 & - \\
\hline $\begin{array}{l}\text { Unknown Vineyard - } \\
\text { Moody Vineyard }\end{array}$ & $\begin{array}{l}\text { Maryhill (Deschutes } \\
\text { River) }\end{array}$ & 15.9 & - \\
\hline $\begin{array}{l}\text { Unknown Vineyard - near } \\
\text { Cascade Cliffs }\end{array}$ & Wishram & 6.8 & - \\
\hline $\begin{array}{c}\text { Unknown Vineyard - Old } \\
\text { Highway Road }\end{array}$ & Lyle & 1.1 & - \\
\hline $\begin{array}{c}\text { Unknown Vineyard - Phil } \\
\text { Jones Old Vineyard }\end{array}$ & Underwood Mountain & 12.7 & - \\
\hline \multicolumn{4}{|c|}{ Total Acreage } \\
\hline
\end{tabular}




\section{CHAPTER 6: CONCLUSIONS}

As of September 2013, 36 wineries and 82 vineyards have been located within the CGWR, totaling to 513.0 hectares (1268 acres) of land designated to vineyards in this region. The average size of vineyards in the CGWR is 15 acres (6.1 hectares). At least 41 grape varieties are planted among these vineyards, however, estimations provided by the vitners suggest that 21 varieties account for $98 \%$ of the total grape acreage estimations provided by the vintners. Pinot Noir is the most commonly planted grape variety in the CGWR, followed by Syrah and Chardonnay.

In the Columbia Gorge AVA, cool climate grape varieties dominate, with Pinot Noir, Chardonnay and Pinot Gris being the most common grape varieties planted. With the exception of the 130 acres of Pinot Noir planted at Sunshine Mountain Vineyard, vineyards in the Columbia Valley AVA are dominated by warm climate grape varieties, including Syrah, Merlot and Zinfandel. In general, vintners have planted grape varieties typical for the cool, intermediate and warm macro-climates located in the CGWR. This suggests that the diversity in grape variety plantings is reflective of the diverse climatic conditions and not only experimentation by the vintners (Jones, 2010). Grape variety acreage estimations collected in this study were not provided for 12 vineyards $(15 \%$ of the total vineyard acreage), leaving the potential of more varietals in the region.

Completed growers surveys concluded that 37 vineyards have vines that are selfrooted, 15 sites have both grafted and self-rooted vines, 10 site have vines that are fully grafted and 21 sites provided no response. $29 \%$ of all the vineyards in the CGWR practice dry-land farming and are located mainly at the western CGWR boundaries. 
Irrigation practices appear to reflect the decrease in precipitation west to east, with dryland farming taking place above 60 centimeters of annual precipitation.

The average annual precipitation measured at vineyard sites using 1981 to 2010 PRISM data ranges from 118 centimeters (47 inches) on Underwood Mountain to 27.4 centimeters (10.8 inches) at sites near Maryhill, Washington. The average precipitation measured during the growing season from 1981 to 2010 is less than 4.0 centimeters (1.6 inches), causing minimal rainfall hazards during the growing season. Average growing season temperatures measured at vineyard sites ranges from $13.7^{\circ} \mathrm{C}\left(55.7^{\circ} \mathrm{F}\right)$ to $17.7^{\circ} \mathrm{C}$ $\left(63.9^{\circ} \mathrm{F}\right)$ and growing degree days range from 871 for ${ }^{\circ} \mathrm{C}\left(1567\right.$ for $\left.{ }^{\circ} \mathrm{F}\right)$ to 1664 for ${ }^{\circ} \mathrm{C}$ $\left(2994\right.$ for $\left.{ }^{\circ} \mathrm{F}\right)$.

Three separate macro-climates are defined in the region using average growing season temperatures (GST)'s (Jones et al., 2010). A cool, intermediate and warm macroclimate is defined using average growing degree days. Majority of the vineyards $(58 \%$ of the vineyard acreage) are planted in an intermediate climatic regime, while $29 \%$ of the vineyard acreage is located in a cool climatic regime, $9 \%$ in a warm climatic regime (17 to $19^{\circ} \mathrm{C}$ ) and $4 \%$ located on the macro-climate boundaries. The macro-climate shifts from a cool-climate regime to an intermediate regime between higher and lower elevations sites between Underwood Mountain and Hood River. An intermediate macro-climate begins at lower elevations in the Hood River Valley, and extends to higher elevations south and east of The Dalles, Oregon. A warm macro-climate begins at low elevations near Dallesport and continues at low elevations along the Columbia River. 
Three macro-climates are also defined in the CGWR using the more commonly used growing degree days and the Winkler Index, updated by Jones et al. (2010). 80\% of the vineyard acreage is located in Region Ia or Region Ib, which is suitable for early ripening varieties and is comparable to climates in Champagne, France, Burgundy, France and Willamette Valley, Oregon. 19\% of the vineyard acreage is located in Region II, a region suitable for early to mid-season table wines and similar in temperatures to Bordeaux, France and the Umpqua Valley, Oregon. The climatic regime boundaries defined by the updated Winkler Index follow a similar pattern defined by the average growing season temperatures, with growing degree days increasing towards the east.

The elevation among the vineyard sites ranges from 29 meters (95 feet) to 548 meters (1799 feet) above sea level. Slopes used to plant grapes ranges from 0 to $31^{\circ}$, with majority of the vineyards containing an east $(29.4 \%)$, southeast $(25.1 \%)$ or south $(14.4 \%)$ facing slope. $99 \%$ of the vineyards are located on a dominantly flat topography with no concavity in the topography.

About $46 \%$ of the vineyards are planted on soils that formed in loess. The dominant geological bedrock that is mapped at sites not underlain by loess deposits include The Dalles Formation (8.0\%), Quaternary Basalt (19.6\%), Columbia River Basalt Group (7.5\%), Missoula Flood deposits (9.1\%), Pliocene Basalt (3.0\%), Young Surficial Deposits (3.0\%), Lahar Deposits (2.3\%) and Quaternary Basaltic Andesite/Andesite. Missoula Floods have influenced soil characteristics at vineyards in the CGWR. Upper elevations of the floods at the Deschutes River Mouth (323 meters; 970 feet) descend going westward to Hood River (280 meters; 840 feet). Above those elevations, loess 
dominates in the soil. In back canyons to the floods, slackwater deposits of graded beds of sand (bottom) to silt (top) form the parent material. In high velocity zones of the Floods, skeletal (>35\% gravel) soils dominate.

Vineyards are planted on 30 separate soil series. The Walla Walla Series, located in the eastern CGWR, and the Chemawa Series, located on Underwood Mountain, account for over half $(53.6 \%)$ of the growing acreage soil. $96 \%$ of the vineyards contain soils with a loamy texture (mixture of clay and silt), while $4 \%$ have a sandy texture. All of the soils mapped at vineyard sites are well drained and defined by a xeric moisture regime. $41 \%$ of the soils contain a Bt-horizon and are greater than 15,000 years old; 15,000 years is the minimum time frame to form a Bt-horizon in this region (Birkeland, 1999). All other soils are younger than 15,000 years old and contain Bw-horizon or no Bhorizon. Mollisols (298 hectares), Andisols (222 hectares) and Alfisols (170 hectares) dominate the soil orders of the vineyards, followed by Entisols ( 52 hectares) and Inceptisols (44 hectares).The region is broken into seven soil sub-regions based on the clustering of common soil series among vineyard sites. Each sub-region has at least one soil series that is not planted at vineyards in other sub-regions.

It is suggested that future work focus on separating the region into five sub-AVAs to better reflect the diversity of terroir conditions in this region. One possible sub-AVA could be Underwood Mountain, where vineyard soils originated from young basalt flows (mainly Chemawa Series) and sites are predominantly planted within a cool macroclimate. The volcanic deposits (lahars, basalt flows) in the Hood River Valley are unique to this region and can potentially be used to define a new sub-AVA. The Hood and Oak 
Grove Series (both Ultic Haploxeralfs) and cool climate areas dominate in the upper elevations in the Hood River Valley. At lower elevations, skeletal Ultic Haploxerolls and intermediate climate areas dominate and are located on predominantly Missoula Flood deposits. Vineyards located in the intermediate climatic zone near Lyle and Mosier are unique in that lower elevation vineyards are planted on Missoula Flood gravels and silts (Balake soil series), while those at higher elevations are planted in loess deposits (Gunn soil series). The possible Dallesport sub-AVA has a warm climate, and the terroir changes from sand dunes (Ewall soil series) at the lowest elevations, to slightly higher elevation skeletal soils in the Missoula Flood zone (Dallesport soil) to the loess soils at higher elevations above the Missoula Floods (Fisherhill soil). The Dalles sub-AVA has two dominant soils: the Cherryhill soil above the Missoula Floods in the loess and the Chenoweth soil below the flood line. The warm climatic regime, loess and Missoula Flood derived soils found at sites beginning in Dallesport and The Dalles and then eastward along the Columbia River are typical of conditions found among vineyards in the Columbia Valley AVA

Other sub-AVAs such as those in the Willamette Valley have been separated by specific soil series and therefore, the seven soil-sub regions characterized in this study can act as a guide to separating the region based on soil series alone. More site specific field work and conversations with vintners in this region should be conducted before the region is broken into sub-AVAs. Breaking the region into multiple sub-AVAs would better reflect the diverse and unique set of terroir conditions that are affecting the wine produced in the CGWR. 


\section{CHAPTER 7: FUTURE WORK}

The current AVA boundaries in the CGWR do not reflect the current physical terroir conditions among vineyard sites in the CGWR. In fact, one vineyard (the Pines Old Zinfandel Vineyard) is cut in half by the boundary between then Columbia Valley AVA and Columbia Gorge AVA. Therefore, it is suggested that future work focus on separating the region into sub-AVAs in order to highlight the diversity in terroir conditions among vineyard sites. Similarities in soil series, geological deposits, climatic conditions and topography shown in this study can serve as a guide for further sub-AVA designation. More site specific field work and conversations with vintners should take place before separations of the current boundaries take place. In the CGWR, wind is prevalent along the CGWR and is expected to effect the grapes in the region, especially with the timing of bud break and ripening periods. Therefore, future work in the CGWR should aim at analyzing the wind in addition to other terroir factors. 


\section{REFERENCES}

Allen, J. E., Burns, M., and Burns, S., 2009, Cataclysms on the Columbia : the great Missoula floods, Portland, Or., Ooligan Press, Openbook series, 204.

Amerine, M. A., and Winkler, A. J., 1944, Composition and quality of musts and wines of California grapes, Volume 15, Hilgardia, p. 493-675.

Columbia Gorge Wine Association, 2012, Columbia Gorge Winegrowers: http://www.columbiagorgewine.com/

Columbia Gorge Association, 2002, Columbia Gorge Appellation American Viticultural Area Petition, in Bureau of Alcohol, Tobacco and Firearms-Regulations Division

Barnard, K. N., 2009, Geology and Wine in Missouri: Spatial Analysis of Terroir using a Geographic Information System and Remote Sensing [Master of Science, Geospatial Sciences in Geography and Geology: Missouri State University, 204 p.

Benito, G., and O'Connor, J. E., 2003, Number and size of last-glacial Missoula floods in the Columbia River valley between the Pasco Basin, Washington, and Portland, Oregon, Volume 115: Geological Society of America Bulletin, p. 624-638.

Birkeland, P. W., 1999, Soils and geomorphology, New York, Oxford University Press, $3^{\text {rd }}$ edition, p.430.

Bugenhagen, M., 2008, The Code of Federal Regulations, Title 27 - Alcohol, Tobacco Products and Firearms, Parts 1-39, in The Alcohol and Tobacco Tax and Trade Bureau and the Bureau of Alcohol, Tobacco, Firearms and Explosives, Department of Justice, ed., Volume 1: Washington, DC, The Office of Federal Register National Archives and Records Administation, p. 262-263.

Burns, S., 2012, The importance of soil and geology in tasting terroir with a case history from the Willamette Valley, Oregon, in Dougherty, P. H., ed., The Geography of Wine, Springer, Netherlands, p. 95-108.

Daly, C., Halbleib, M., Smith, J. I., Gibson, W. P., Doggett, M. K., Taylor, G. H., Curtis, J., and Pasteris, P. P., 2008, Physiographically sensitive mapping of climatological temperature and precipitation across the conterminous United States: International Journal of Climatology, v. 28, no. 15, p. 2031-2064.

Environmental Systems Research Institute, I., ArcGIS Online: Redlands, CA, Environmental Systems Research Institute, Inc.

Jones, G. V., 2011, The Climate and Landscape Potential for Quality Wine Production in the Snake River Valley AVA: unpublished report.

Jones, G. V., Duff, A. A., Hall, A., and Myers, J. W., 2010, Spatial analysis of climate in winegrape growing regions in the Western United States: American Journal of Enology and Viticulture, v. 61, no. 3, p. 313-326.

Jones, G. V., Hille, P., Pine, J., and Jones, H. E., 2002, Mapping Varietal Potential for Quality Wines in Oregon using PRISM Spatial Climate Dara, American Meteorological Society, 13th Conference on Applied Climatology: Portland, Oregon.

Jones, G. V., Snead, N., and Nelson, P., 2004, Geology and wine 8. modeling viticultural landscapes: a GIS analysis of the terroir potential in the Umpqua Valley of Oregon: Geoscience Canada, v. 31, no. 4, p. 167-178. 
Larsen, M., 2014, Washington State's most southern Vineyard, Good Fruit Grower, Washington State Fruit Commission: http:/www.goodfruit.com/washingtonstates-most-southern-vineyard/.

Ma, L., Madin, I. P., Olson, K. V., and Watzig, R. J., 2009, Oregon Geologic Data Compilation: Oregon Department of Geology and Mineral Industries, scale 1:100,000: http://www.oregongeology.org/sub/ogdc/index.htm.

McClaughry, J. D., Wiley, T. J., Conrey, R. M., Jones, C. B., and Kennetg E. Lite, J., 2012a, Digital Geological Map of the Hood River Valley, Hood River and Wasco Counties, Oregon: Oregon Department of Geology and Mineral Industries Open File Report O-12-03, p. 2-5.

McClaughry, J. D., Wiley, T. J., Conrey, R. M., Jones, C. B., and Lite, K. E., 2012b, Open-File Report O-12-03, Digital geologic map of the Hood River Valley, Hood River and Wasco Counties, Oregon: Deparment of Geology and Mineral Industries, scale 1:36,000.

Meinert, L. D., and Busacca, A. J., 2000, Geology and Wine 3. Terroirs of the Walla Walla Valley appellation, southeastern Washington State, USA: Geoscience Canada; Volume 27, Number 4, p. 149.

Merinert, L.D., and Busacca, A.J., 2002, Geology and Wine 6. Terroir of the Red Mountain Appellation, Central Washington State, U.S.A: Geoscience Canada; Volume 29, Number 4 (2002).

Norman, D. K., and Busacca, A. J., 2004, Geology of the Yakima Valley Wine CountryA Geologic Field Trip Guide from Stevenson to Zillah, Washington: Washington Division of Geology and Earth Resources Field Trip Guide 1.

Oregon Climate Service, 2014: http://www.ocs.orst.edu.

Peale, P., 2013, WSDA-2012 Washington State AVA's: ESRI.

Pogue, K., 2012, Thoughts on becoming a terroirist, Volume 34: Walla Walla, WA, Whitman Magazine:Whitman College, p. 12-13.

Pogue, K. R., 2009, Folds, floods, and fine wine: Geologic influences on the terroir of the Columbia Basin: Field Guides, Geological Society of America, v. 15, p. 1-17.

Reidel, S. P., Campbell, N. P., Fecht, K. R., and Lindsey, K. A., 1994, Late Cenozoic Structure and Stratigraphy of South-Central Washington, Volume 80: Washington Division of Geology Earth Resources Bulletin, p. 159-180.

Reidel, S. P., Fecht, K. R., Hagood, M. C., and Tolan, T. L., 1989, The geologic evolution of the central Columbia Plateau: Geological Society of America Special Papers, v. 239, p. 247-264.

Soil Survey Staff, 2010, Keys to Soil Taxonomy: Washington, D.C., U.S. Department of Agriculture, Natural Resources Conservation Service, p. v, 338 p.

Soil Survey Staff, 2012a, Gridded Soil Survey Geographic (gSSURGO) Database for Oregon, United States Department of Agriculture, Natural Resources Conservation Service.

Soil Survey Staff, 2012b, Gridded Soil Survey Geographic (gSSURGO) Database for Washington, United States Department of Agriculture, Natural Resources Conservation Service. 
United States Geological Survey, 2013a, USGS NED n46w121 1/3 arc-second 20131 x 1 degree GridFloat.

United States Geological Survey, 2013b, USGS NED n46w122 1/3 arc-second $20131 \mathrm{x}$ 1 degree ArcGrid.

Tolan, T. L., Reidel, S. P., Beeson, M. H., Anderson, J. L., Fecht, K. R., and Swanson, D. A., 1989, Revisions to the estimates of the areal extent and volume of the Columbia River Basalt Group: Geological Society of America Special Papers, v. 239, p. 1-20.

Unwin, T., 2012, Terroir: at the heart of geography, in Dougherty, P. H., ed., The Geography of Wine, Springer, Netherlands, p. 37-48.

Waitt, R. B., 1985, Case for periodic, colossal jökulhlaups from Pleistocene glacial Lake Missoula: Geological Society of America Bulletin, v. 96, no. 10, p. 1271-1286.

Washington Department of Natural Resources Staff, 2010, Digital Geology of Washington State at 1:100,000-scale: Washington Division of Geology and Earth Resources, scale 1:100,000.

Washington State University Staff, 1988, AgWeatherNet, Volume 2014: Washington State University, College of Agriculture, Human, and Natural Resource Sciences. 


\section{APPENDICES}

\section{Appendix A: AgWeather Station Data}

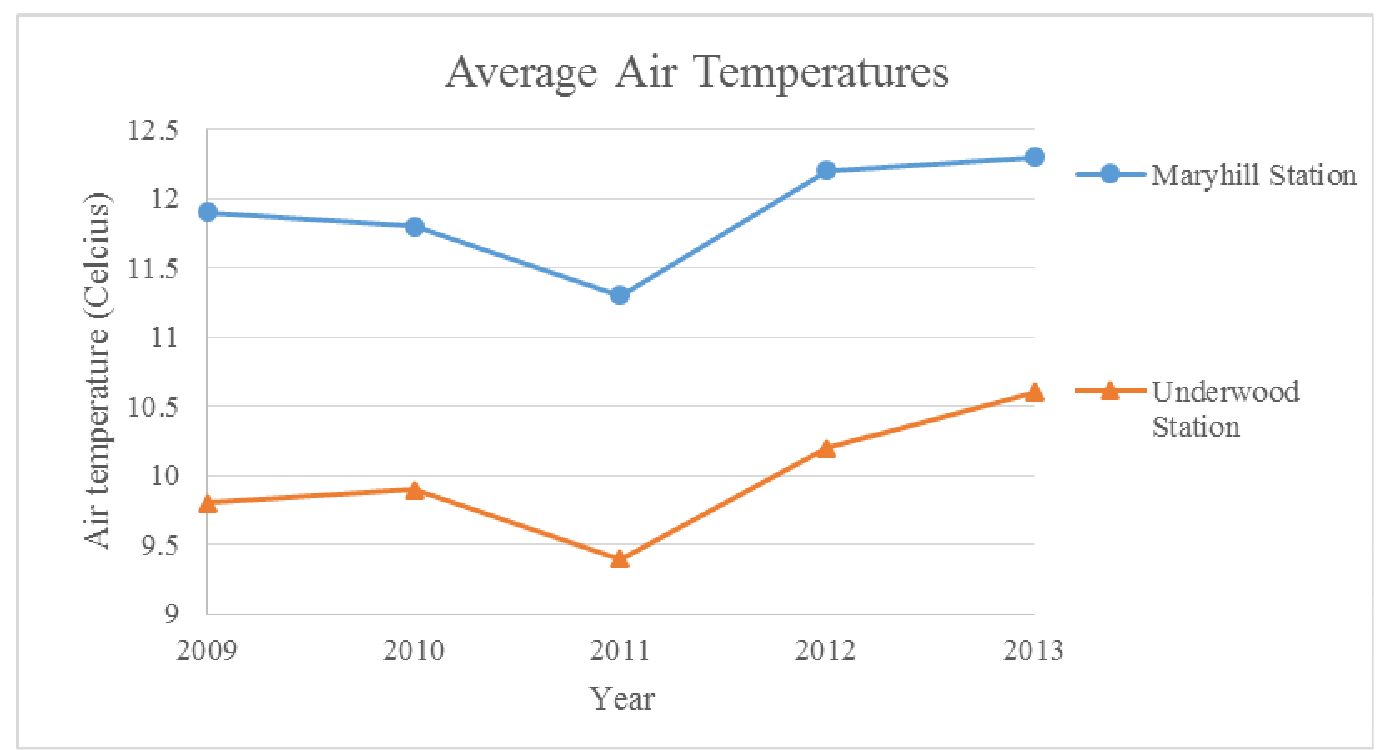

Appendix A - 1. The Maryhill Station, planted near Gunkel Vineyards, consistently has higher annual air temperatures compared to the Underwood Station, located near Underwood Mountain Vineyards. On average, the temperatures at Maryhill are $2{ }^{\circ} \mathrm{C}$ higher than what is measured at the Underwood station.

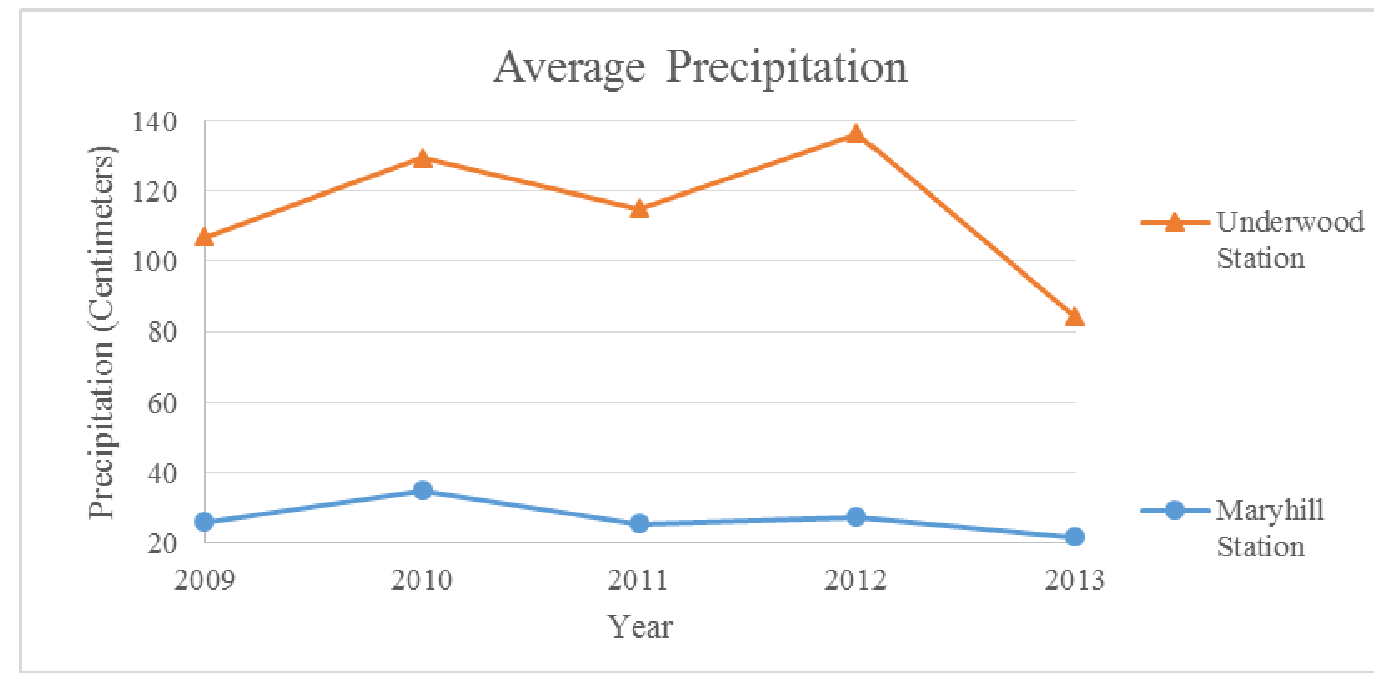

Appendix A - 2. The annual precipitation varied between the two stations by as much as 43 centimeters in 2012 . 


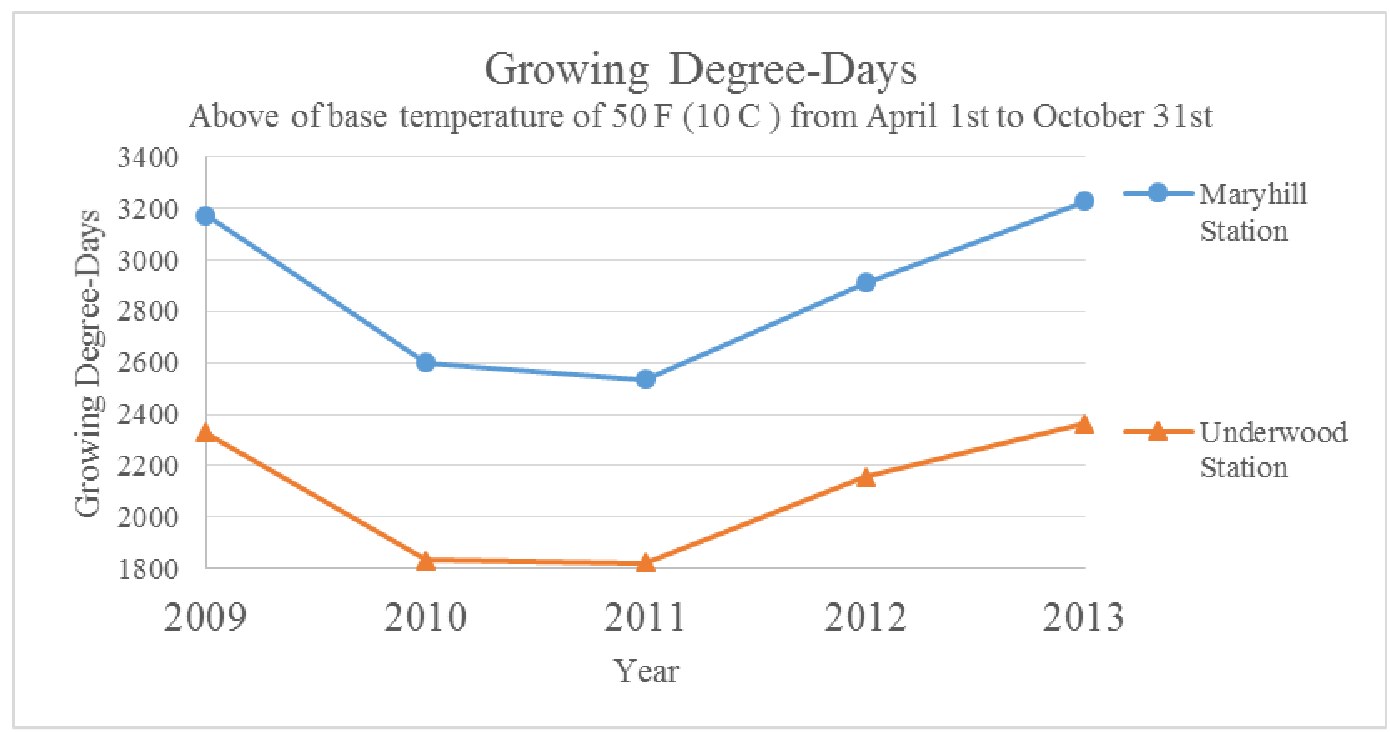

Appendix A - 3. Growing degree days are consistently higher at the Maryhill site compared to the Underwood Site. 


\section{Appendix B: Growers Survey Results}

Appendix B - 1. The wines that wineries in the CGWR have made in the present and past. Pinot Noir, Chardonnay and Syrah dominate.

\begin{tabular}{lccccc}
\hline & Wine List & \# of Wineries & & Wine List & \# of Wineries \\
\hline 1 & Pinot Noir & 21 & 22 & Petit Sirah & 2 \\
2 & Chardonnay & 19 & 21 & Mourvedre & 2 \\
3 & Syrah & 19 & 23 & Albarino & 2 \\
4 & Merlot & 15 & 24 & Counoise & 1 \\
5 & Pinot Gris & 12 & 25 & Dolcetto & 1 \\
6 & Riesling & 12 & 26 & Fernao Pires & 1 \\
7 & Cabernet Sauvignon & 11 & 27 & Gruner Veltliner & 1 \\
8 & Gewurztraminer & 9 & 28 & Lemberger & 1 \\
9 & Zinfandel & 9 & 29 & Marsanne & 1 \\
10 & Barbera & 7 & 30 & Marechal Foch & 1 \\
11 & Cabernet Franc & 7 & 31 & Petit Verdot & 1 \\
12 & Grenache & 7 & 32 & Pinot Blanc & 1 \\
13 & Sangiovese & 7 & 33 & Pinot Grigio & 1 \\
14 & Sauvignon Blanc & 7 & 34 & Roussanne & 1 \\
15 & Tempranillo & 7 & 35 & Sausao & 1 \\
16 & Malbec & 5 & 36 & Semillon & 1 \\
17 & Primitivo & 5 & 37 & Symphony & 1 \\
18 & Nebbiolo & 4 & 38 & Tinto Cao & 1 \\
19 & Viognier & 4 & 39 & Zweigelt & 1 \\
20 & Moscato & 2 & & & \\
\hline
\end{tabular}

$\overline{\bar{u}}$ 
Appendix B - 2. Growers Survey Information collected for the 36 wineries in the survey.

\begin{tabular}{|c|c|c|c|}
\hline Winery & $\begin{array}{l}\text { Year Established } \\
\text { (or first vintage) }\end{array}$ & Regions in which grapes are sourced & Certifications \\
\hline $\begin{array}{c}15 \text { Mile Winery (Bolton } \\
\text { Cellars) }\end{array}$ & 2012 & $\mathrm{n} / \mathrm{a}$ & $\mathrm{n} / \mathrm{a}$ \\
\hline Analemma Wines & 2010 & Columbia Gorge AVA & $\mathrm{n} / \mathrm{a}$ \\
\hline Aniche Cellars & 2008 & $\begin{array}{c}\text { Columbia Gorge AVA,Columbia Valley AVA, } \\
\text { Horeshaven Hills, Yakima Valley AVA, } \\
\text { Rattlesnake Hills AVA }\end{array}$ & $\begin{array}{l}\text { biodynamic } \\
\text { and organic }\end{array}$ \\
\hline Cascade Cliffs Winery & 1986 & $\begin{array}{c}\text { Estate, Columbia Gorge AVA, Columbia Valley } \\
\text { AVA, Horsehaven Hills ABA }\end{array}$ & $\begin{array}{l}\text { biodynamic } \\
\text { practices not } \\
\text { certified }\end{array}$ \\
\hline Cathedral Ridge Winery & & Columbia Gorge AVA, Columbia Valley AVA & none \\
\hline Cerulean Wine & 2008 & Columbia Gorge AVA, Columbia Valley AVA & $\mathrm{n} / \mathrm{a}$ \\
\hline Cor Cellars & 2004 & $\begin{array}{c}\text { Estate, Columbia Gorge AVA, Columbia Valley } \\
\text { AVA, Wahluke Slope AVA, Horsehaven Hills } \\
\text { AVA, Yakima Valley AVA }\end{array}$ & none \\
\hline $\begin{array}{l}\text { Deere Run Farm and } \\
\text { Vineyard }\end{array}$ & $\mathrm{n} / \mathrm{a}$ & $\mathrm{n} / \mathrm{a}$ & $\mathrm{n} / \mathrm{a}$ \\
\hline Domaine Poullion & & $\begin{array}{c}\text { Estate, Columbia Gorge AVA, Columbia Valley } \\
\text { AVA, Horsehaven Hills ABA }\end{array}$ & $\begin{array}{l}\text { pursuing } \\
\text { biodynamic \& } \\
\text { organic }\end{array}$ \\
\hline
\end{tabular}


Appendix B - 2. Growers Survey Information collected for the 36 wineries in the survey.

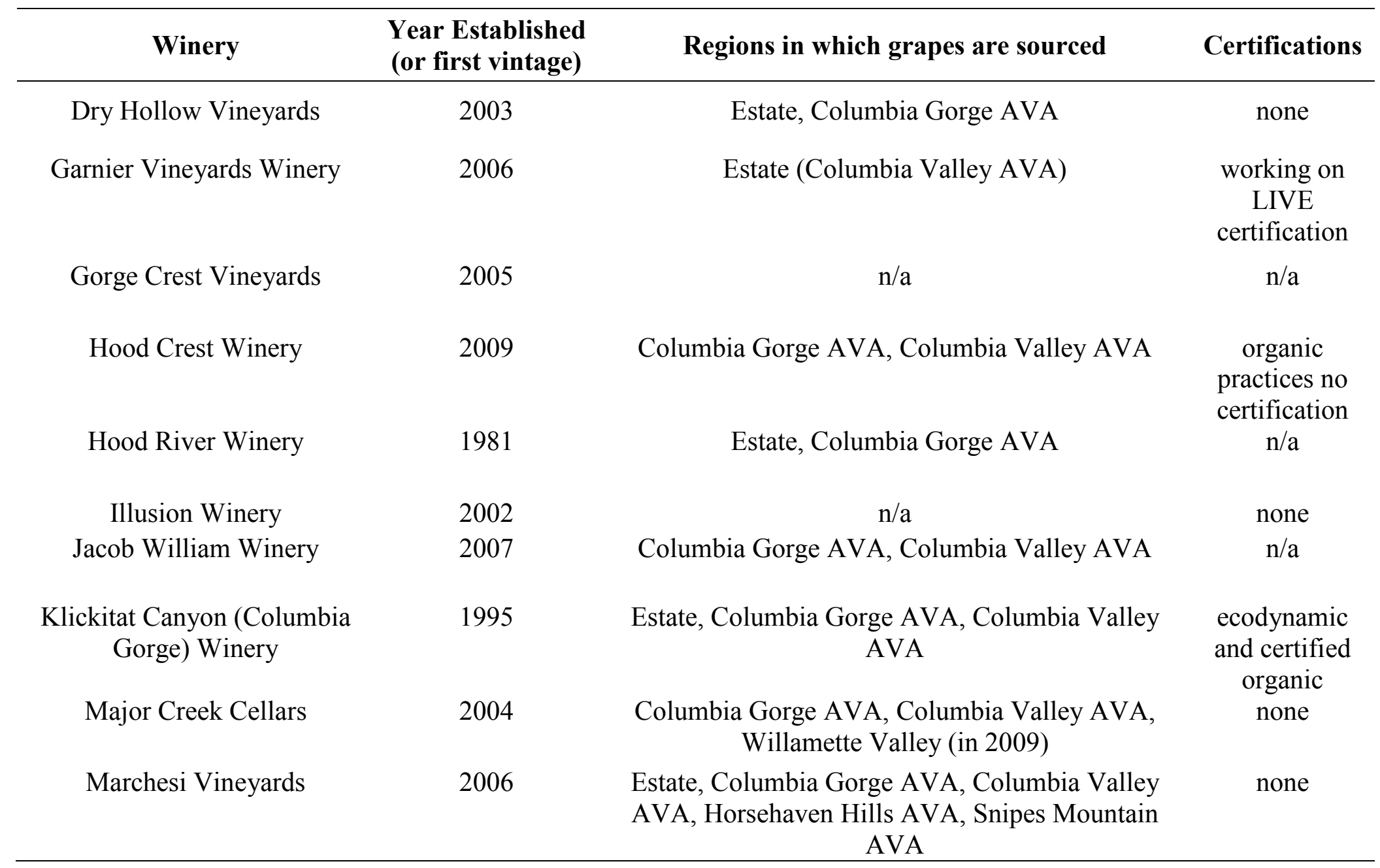


Appendix B - 2. Growers Survey Information collected for the 36 wineries in the survey.

\begin{tabular}{|c|c|c|c|}
\hline Winery & $\begin{array}{l}\text { Year Established } \\
\text { (or first vintage) }\end{array}$ & Regions in which grapes are sourced & Certifications \\
\hline Marshals Winery & 1998 & Columbia Valley AVA & $\mathrm{n} / \mathrm{a}$ \\
\hline Maryhill Winery & 1999 & $\begin{array}{c}\text { Estate, Columbia Valley AVA, Walla Walla AVA, } \\
\text { Rattlesnake Hills AVA, Yakima Valley AVA, } \\
\text { Horsehaven Hills AVA }\end{array}$ & $\mathrm{n} / \mathrm{a}$ \\
\hline Maison de Glace Winery & 2011 & $\mathrm{n} / \mathrm{a}$ & $\mathrm{n} / \mathrm{a}$ \\
\hline $\begin{array}{l}\text { Memaloose/Idiots Grace } \\
\text { Winery }\end{array}$ & 2006 & Estate, Columbia Gorge AVA & none \\
\hline Mt.Hood Winery & 2002 & $\begin{array}{c}\text { Estate, Columbia Gorge AVA \& Columbia Valley } \\
\text { AVA }\end{array}$ & none \\
\hline Naked Winery & 1999 & $\begin{array}{c}\text { Columbia Gorge AVA, Columbia Valley AVA, } \\
\text { California (Lodi), Willamette Valley }\end{array}$ & $\begin{array}{l}\text { suistainable } \\
\text { practieces } \\
\text { hand harvest } \\
\text { grapes }\end{array}$ \\
\hline Pheasant Valley Winery & 2003 & $\begin{array}{l}\text { Estate, Columbia Gorge AVA \& Columbia Valley } \\
\text { AVA }\end{array}$ & organic \\
\hline $\begin{array}{l}\text { Phelps Creek Winery/ Mt. } \\
\text { Definace Wine Company }\end{array}$ & 2001 & $\begin{array}{l}\text { Estate, Columbia Gorge AVA \& Columbia Valley } \\
\text { AVA }\end{array}$ & $\begin{array}{l}\text { organic } \\
\text { practices no } \\
\text { certification }\end{array}$ \\
\hline Pour Moore Wine & 2012 & Columbia Valley AVA, Horsehaven Hills AVA & $\begin{array}{l}\text { organic } \\
\text { practices but } \\
\text { not certified }\end{array}$ \\
\hline
\end{tabular}


Appendix B - 2. Growers Survey Information collected for the 36 wineries in the survey.

\begin{tabular}{|c|c|c|c|}
\hline Winery & $\begin{array}{l}\text { Year Established } \\
\text { (or first vintage) }\end{array}$ & Regions in which grapes are sourced & Certifications \\
\hline $\begin{array}{l}\text { Quenett \& Copa Di Vino } \\
\text { Winery }\end{array}$ & 2002 & Estate, Columbia Valley AVA & $\mathrm{n} / \mathrm{a}$ \\
\hline Springhouse Cellars & 2007 & Columbia Gorge AVA & $\mathrm{n} / \mathrm{a}$ \\
\hline Stoltz Vineyards & 2006 & Columbia Gorge AVA & none \\
\hline Syncline Winery & 1999 & $\begin{array}{c}\text { Columbia Gorge AVA, Red Mountain AVA, } \\
\text { Horsehaven Hills AVA }\end{array}$ & $\begin{array}{l}\text { biodynamic } \\
\text { practices }\end{array}$ \\
\hline The Pines 1852 & 2001 & $\begin{array}{c}\text { Estate, Columbia Gorge AVA \& Columbia Valley } \\
\text { AVA }\end{array}$ & none \\
\hline Waving Tree Winery & $\mathrm{n} / \mathrm{a}$ & Estate, Horsehaven Hills AVA & $\mathrm{n} / \mathrm{a}$ \\
\hline White Salmon Vineyard & 2003 & $\begin{array}{c}\text { Columbia Gorge AVA, Columbia Valley AVA, } \\
\text { Yakima Valley AVA, California (Napa, } \\
\text { Mendacino, Sonoma) }\end{array}$ & none \\
\hline Wind River Cellars & 1995 & Columbia Gorge AVA, Horsehaven Hills & none \\
\hline Wy'East Vineyards & 1996 & $\begin{array}{c}\text { Estate, Columbia Gorge AVA, Willamette Valley } \\
\text { AVA }\end{array}$ & none \\
\hline Vineto Wines & 2014 & Estate, Columbia Gorge AVA & $\mathrm{n} / \mathrm{a}$ \\
\hline
\end{tabular}


Appendix B - 3. Growers Survey Information collected for the 82 vineyards found in this study.

\begin{tabular}{|c|c|c|c|c|c|}
\hline $\begin{array}{c}\text { Vineyar } \\
\text { d ID }\end{array}$ & Vineyard Name & Closest City & State & AVA & $\begin{array}{c}\text { Participated in } \\
\text { Survey }\end{array}$ \\
\hline 1 & Abel Vineyard & Hood River & OR & $\mathrm{CG}$ & yes \\
\hline 2 & Allegre Vineyards & Hood River & OR & CG & yes \\
\hline 3 & Annala Vineyard & Hood River & OR & $\mathrm{CG}$ & no \\
\hline 4 & Arcadia Vineyard & Underwood & WA & $\mathrm{CG}$ & no \\
\hline 5 & Atavus Vineyard & White Salmon & WA & CG & yes \\
\hline 6 & Bangsund Vineyard & The Dalles & OR & $\mathrm{CV}$ & yes \\
\hline 7 & Bethany in the Gorge & Dallesport & WA & $\mathrm{CV}$ & yes \\
\hline 8 & Blind Dog Vineyard & The Dalles & OR & $\mathrm{CG}$ & yes \\
\hline 9 & Blue Chip Farm & Hood River & OR & CG & yes \\
\hline 10 & Cascade Cliffs Vineyard & Wishram & WA & $\mathrm{CV}$ & yes \\
\hline \multirow[t]{2}{*}{11} & Cathedral Ridge Vineyard Demonstrator & & & & \\
\hline & Vineyard & Hood River & OR & CG & yes \\
\hline 12 & Celilo Vineyard & Underwood & WA & $\mathrm{CG}$ & yes \\
\hline 13 & Chukar Ridge Vineyard & Dallesport & WA & $\mathrm{CV}$ & yes \\
\hline 14 & Columbia Gorge Vineyard & Hood River & OR & $\mathrm{CG}$ & yes \\
\hline 15 & Columbia River View Vineyard & Underwood & WA & CG & yes \\
\hline 16 & Cor Cellars Estate Vineyard & Lyle & WA & $\mathrm{CG}$ & yes \\
\hline 17 & Crooked Vineyard & Underwood & WA & CG & yes \\
\hline 18 & Dampier Vineyard & Underwood & WA & $\mathrm{CG}$ & yes \\
\hline 19 & Davidson Hill Vineyards & Hood River & OR & $\mathrm{CG}$ & yes \\
\hline \multirow{2}{*}{20} & Dean McAllister Vineyard (Power Block & & & & \\
\hline & Vineyard) & The Dalles & OR & $\mathrm{CV}$ & yes \\
\hline 21 & Duke's Valley Vineyard & Odell & OR & $\mathrm{CG}$ & yes \\
\hline
\end{tabular}


Appendix B - 3. Growers Survey Information collected for the 82 vineyards found in this study.

\begin{tabular}{|c|c|c|c|c|c|}
\hline $\begin{array}{c}\text { Vineyar } \\
\text { d ID }\end{array}$ & Vineyard Name & Closest City & State & AVA & $\begin{array}{c}\text { Participated in } \\
\text { Survey }\end{array}$ \\
\hline 22 & Energia Vineyards & Underwood & WA & $\mathrm{CG}$ & yes \\
\hline 23 & From Water To Wine Vineyard & Dallesport & WA & $\mathrm{CV}$ & yes \\
\hline 24 & Garnier Vineyard & Mosier & OR & $\mathrm{CG}$ & yes \\
\hline 25 & Gorge Crest Vineyards & Underwood & WA & $\mathrm{CG}$ & yes \\
\hline 26 & Graves Vineyard & Dallesport & WA & $\mathrm{CV}$ & yes \\
\hline 27 & Gunkell Vineyards (Maryhill Winery) & Maryhill & WA & $\mathrm{CV}$ & no \\
\hline 28 & Gunkell Vineyards (Jacob Williams Winery) & Wishram & WA & $\mathrm{CV}$ & no \\
\hline 29 & Hamm's Vineyard & Lyle & WA & $\mathrm{CG}$ & yes \\
\hline 30 & Hannah's Bench Vineyard & Lyle & WA & CG & yes \\
\hline 31 & HD Vineyards LLC & The Dalles & OR & $\mathrm{CV}$ & yes \\
\hline 32 & Hi Valley Vineyard & The Dalles & OR & $\mathrm{CV}$ & yes \\
\hline 33 & Hogback Ridge Vineyard & The Dalles & OR & $\mathrm{CV}$ & yes \\
\hline 34 & Hood Crest Estate Vineyard & Hood River & OR & CG & yes \\
\hline 35 & Hood River Winery Estate Vineyards & Hood River & OR & $\mathrm{CG}$ & yes \\
\hline 36 & Idiots Grace Vineyard (The Annex) & Mosier & OR & CG & yes \\
\hline 37 & Jewett Creek Vineyard & White Salmon & WA & CG & yes \\
\hline 38 & Kortage Vineyard & The Dalles & OR & CG & yes \\
\hline 39 & Lamonti Vineyard & Underwood & WA & CG & yes \\
\hline 40 & Lewis Vineyard & The Dalles & OR & $\mathrm{CG}$ & yes \\
\hline 41 & Marchesi Estate Vineyard & Hood River & OR & CG & yes \\
\hline 42 & Marquem Vineyards (Gorge Estate Vineyards) & Klickitat & WA & $\mathrm{CV}$ & yes \\
\hline 43 & Marshals Estate Vineyard & Dallesport & WA & $\mathrm{CV}$ & yes \\
\hline 44 & McDuffee Vineyard & The Dalles & OR & $\mathrm{CG}$ & yes \\
\hline
\end{tabular}


Appendix B - 3. Growers Survey Information collected for the 82 vineyards found in this study.

\begin{tabular}{cllccc}
\hline $\begin{array}{c}\text { Vineyar } \\
\text { d ID }\end{array}$ & Vineyard Name & Closest City & State & AVA & $\begin{array}{c}\text { Participated in } \\
\text { Survey }\end{array}$ \\
\hline 45 & Meadowlark Vineyard & Lyle & WA & CG & yes \\
46 & Millenium Vineyard & Hood River & OR & CG & yes \\
47 & Nelson Block Vineyard (Sauter Point) & Lyle & WA & CG & yes \\
48 & Oak Ridge Vineyard & Husum & WA & CG & yes \\
49 & Parkers Vineyard & Lyle & WA & CG & yes \\
50 & Pear Blossom Vineyard & Underwood & WA & CG & yes \\
51 & Phelps Creek Vineyard & Hood River & OR & CG & yes \\
52 & Pheasant Valley Vineyard & Hood River & OR & CG & yes \\
53 & Pine Grove Vineyard & Hood River & OR & CG & yes \\
54 & Rapture Ridge LLC & Wishram & WA & CV & yes \\
55 & Reeds Lane Vineyard & Lyle & WA & CG & yes \\
56 & Roca Vineyard & The Dalles & OR & CV & yes \\
57 & Saddle View Estate & Mosier & OR & CG & yes \\
58 & Scorched Earth Vineyard & Dallesport & WA & CV & yes \\
59 & Silvertooth Vineyard & Husum & WA & CG & yes \\
60 & Smith-Cerne Vineyards & The Dalles & OR & CV & yes \\
61 & Soluna Vineyard & Underwood & WA & CG & yes \\
62 & Steep Creek Ranch & Lyle & WA & CG & yes \\
63 & Stoltz Vineyard & Parkdale & OR & CG & yes \\
64 & Sunshine Mountain Vineyard & The Dalles & OR & CV & yes \\
65 & Swift Water Vineyards & Underwood & WA & CG & yes \\
66 & The Pines Old Vines Vineyard & The Dalles & OR & BOTH & yes \\
67 & Three Sleeps Vineyard & Mosier & OR & CG & no \\
\hline
\end{tabular}


Appendix B - 3. Growers Survey Information collected for the 82 vineyards found in this study.

\begin{tabular}{|c|c|c|c|c|c|}
\hline $\begin{array}{l}\text { Vineyar } \\
\text { d ID }\end{array}$ & Vineyard Name & Closest City & State & AVA & $\begin{array}{c}\text { Participated in } \\
\text { Survey }\end{array}$ \\
\hline 68 & TK Vineyards & The Dalles & OR & $\mathrm{CV}$ & yes \\
\hline 69 & Underwood Mountain Vineyard & Underwood & WA & CG & yes \\
\hline 70 & Van Horn Vineyards & Hood River & OR & $\mathrm{CG}$ & yes \\
\hline 71 & Volcano Ridge & The Dalles & OR & $\mathrm{CG}$ & yes \\
\hline 72 & Waving Tree Vineyards & Maryhill & WA & $\mathrm{CV}$ & yes \\
\hline 73 & White Salmon Vineyard & Underwood & WA & CG & yes \\
\hline 74 & Wy' East Vineyards & Hood River & OR & CG & yes \\
\hline 75 & Zieglar Brother's Family Vineyards & Underwood & WA & $\mathrm{CG}$ & yes \\
\hline 76 & Unknown Vineyard - CGMosier & Mosier & OR & $\mathrm{CG}$ & no \\
\hline 77 & $\begin{array}{l}\text { Unknown Vineyard - Deere Run Farm and } \\
\text { Vineyard } \\
\text { Unknown Vineyard - Emerson Loop Road }\end{array}$ & The Dalles & OR & OUT & no \\
\hline & Vineyard & The Dalles & OR & $\mathrm{CV}$ & no \\
\hline 79 & Unknown Vineyard - Moody Vineyard & Biggs Junction & OR & $\mathrm{CV}$ & no \\
\hline 80 & Unknown Vineyard - near Cascade Cliffs & Wishram & WA & $\mathrm{CV}$ & no \\
\hline 81 & Unknown Vineyard - Old Hwy Rd & Lyle & WA & $\mathrm{CG}$ & no \\
\hline 82 & Unknown Vineyard - Phil Jones Old Vineyard & Underwood & WA & $\mathrm{CG}$ & no \\
\hline 83 & Unknown Vineyard - Windy Ridge Vineyard & Lyle & WA & $\mathrm{CG}$ & yes \\
\hline
\end{tabular}


Appendix B - 4. Growers Survey Information collected for the 82 vineyards found in this study.

\begin{tabular}{ccc}
\hline Vineyard ID & First Year Planted & Irrigation During Growing Season \\
\hline 1 & 2002 & yes \\
2 & 2003 & yes \\
3 & $\mathrm{n} / \mathrm{a}$ & $\mathrm{n} / \mathrm{a}$ \\
4 & $\mathrm{n} / \mathrm{a}$ & dry farming \\
5 & 1965 & dry farming \\
6 & 1974 & yes \\
7 & 1999 & yes \\
8 & 2001 & yes \\
9 & 1985 & $\mathrm{n} / \mathrm{a}$ \\
10 & 1986 & yes \\
11 & 1987 & $\mathrm{n} / \mathrm{a}$ \\
12 & 1973 & dry farming \\
13 & 1991 & yes \\
14 & 1981 & dry farming \\
15 & 2011 & dry farming \\
16 & 2006 & yes \\
17 & 2008 & dry farming \\
18 & 1993 & dry farming \\
19 & 1996 & n/a \\
20 & 1998 & yes \\
21 & 2013 & n/a \\
& & \\
\hline
\end{tabular}

N 
Appendix B - 4. Growers Survey Information collected for the 82 vineyards found in this study.

\begin{tabular}{|c|c|c|}
\hline Vineyard ID & First Year Planted & Irrigation During Growing Season \\
\hline 22 & 2012 & dry farming \\
\hline 23 & 2008 & yes \\
\hline 24 & 2002 & yes \\
\hline 25 & 2005 & $\mathrm{n} / \mathrm{a}$ \\
\hline 26 & 1969 & yes \\
\hline 27 & $\mathrm{n} / \mathrm{a}$ & yes \\
\hline 28 & $\mathrm{n} / \mathrm{a}$ & yes \\
\hline 29 & 2007 & yes \\
\hline 30 & 2004 & yes \\
\hline 31 & 1982 & yes \\
\hline 32 & 1999 & yes \\
\hline 33 & 2005 & yes \\
\hline 34 & 2009 & yes \\
\hline 35 & 1973 & dry farming \\
\hline 36 & 2003 & yes \\
\hline 37 & 1999 & dry farming \\
\hline 38 & 1991 & yes \\
\hline 39 & 2007 & dry farming \\
\hline 40 & 2000 & yes \\
\hline 41 & 2004 & $\mathrm{n} / \mathrm{a}$ \\
\hline 42 & 1998 & $\mathrm{n} / \mathrm{a}$ \\
\hline
\end{tabular}


Appendix B - 4. Growers Survey Information collected for the 82 vineyards found in this study.

\begin{tabular}{ccc}
\hline Vineyard ID & First Year Planted & Irrigation During Growing Season \\
\hline 43 & 1984 & yes \\
44 & 1983 & yes \\
45 & 1993 & dry farming \\
46 & 2000 & dry farming \\
47 & 2007 & n/a \\
48 & 1984 & dry farming \\
49 & 2002 & yes \\
50 & 2008 & dry farming \\
51 & 1990 & dry farming \\
52 & 2004 & yes \\
53 & 1988 & dry farming \\
54 & 1997 & yes \\
55 & 2008 & yes \\
56 & 2004 & yes \\
57 & 2012 & n/a \\
58 & n/a & yes \\
59 & 1983 & dry farming \\
60 & 1968 & yes \\
61 & 2014 & n/a \\
62 & n/a & n/a \\
63 & 2006 & dry farming \\
& & \\
\hline
\end{tabular}


Appendix B - 4. Growers Survey Information collected for the 82 vineyards found in this study.

\begin{tabular}{ccc}
\hline Vineyard ID & First Year Planted & Irrigation During Growing Season \\
\hline 64 & 2013 & $\mathrm{n} / \mathrm{a}$ \\
65 & 2001 & dry farming \\
66 & 1852 & yes \\
67 & $\mathrm{n} / \mathrm{a}$ & $\mathrm{n} / \mathrm{a}$ \\
68 & 2000 & yes \\
69 & 2001 & dry farming \\
70 & 2007 & dry farming \\
71 & 2007 & yes \\
72 & $\mathrm{n} / \mathrm{a}$ & yes \\
73 & 1994 & dry farming \\
74 & 1985 & $\mathrm{n} / \mathrm{a}$ \\
75 & 2000 & dry farming \\
76 & $\mathrm{n} / \mathrm{a}$ & $\mathrm{n} / \mathrm{a}$ \\
77 & $\mathrm{n} / \mathrm{a}$ & $\mathrm{n} / \mathrm{a}$ \\
78 & $\mathrm{n} / \mathrm{a}$ & $\mathrm{n} / \mathrm{a}$ \\
79 & $\mathrm{n} / \mathrm{a}$ & $\mathrm{n} / \mathrm{a}$ \\
80 & $\mathrm{n} / \mathrm{a}$ & $\mathrm{n} / \mathrm{a}$ \\
81 & $\mathrm{n} / \mathrm{a}$ & $\mathrm{n} / \mathrm{a}$ \\
82 & $\mathrm{n} / \mathrm{a}$ & $\mathrm{n} / \mathrm{a}$ \\
83 & $\mathrm{n} / \mathrm{a}$ & $\mathrm{n} / \mathrm{a}$ \\
\hline & & \\
\hline
\end{tabular}


Appendix B - 5. There are 41 separate grape varieties planted among 70 vineyards in the CGWR. Pinot Noir is the most commonly planted variety in both the number of vineyard plantings and in acreage estimates.

\begin{tabular}{|c|c|c|c|c|c|c|c|c|c|}
\hline & \multirow{2}{*}{$\begin{array}{l}\text { Grape Variety } \\
\text { Pinot Noir }\end{array}$} & \multirow{2}{*}{$\begin{array}{c}\begin{array}{c}\text { \# of } \\
\text { vineyard } \\
\text { plantings }\end{array} \\
34\end{array}$} & \multicolumn{2}{|c|}{$\begin{array}{c}\text { Estimated } \\
\text { Acreage \& } \\
\text { Total Acreage } \\
\% \\
\end{array}$} & \multicolumn{2}{|c|}{ Grape Variety } & \multirow{2}{*}{$\begin{array}{c}\text { \# of } \\
\text { vineyard } \\
\text { plantings }\end{array}$} & \multicolumn{2}{|c|}{$\begin{array}{c}\text { Estimated Acreage } \\
\& \\
\text { Total Acreage } \%\end{array}$} \\
\hline 1 & & & 296.4 & $31 \%$ & 22 & Malbec & & 3.9 & $0.4 \%$ \\
\hline 2 & Syrah & 31 & 87.3 & $9 \%$ & 23 & Zweigelt & 2 & 2.5 & $0.3 \%$ \\
\hline 3 & Chardonnay & 18 & 74.8 & $8 \%$ & 24 & Lemberger & 1 & 2.5 & $0.3 \%$ \\
\hline 4 & Pinot Gris & 20 & 65.9 & $7 \%$ & 25 & Muscat & 5 & 1.3 & $0.1 \%$ \\
\hline 5 & Zinfandel & 11 & 57.2 & $6 \%$ & 26 & Primativo & 3 & 1.2 & $0.1 \%$ \\
\hline 6 & Merlot & 17 & 56.0 & $6 \%$ & 27 & Mourvedre & 2 & 1.0 & $0.1 \%$ \\
\hline 7 & Gewurztraminer & 12 & 54.2 & $6 \%$ & 28 & Pinot Blanc & 2 & 1.0 & $0.1 \%$ \\
\hline 8 & Riesling & 19 & 41.1 & $4 \%$ & 29 & Roussanne & 2 & 1.0 & $0.1 \%$ \\
\hline 9 & Cabernet Sauvignon & 12 & 29.0 & $3 \%$ & 30 & Symphony & 2 & 1.0 & $0.1 \%$ \\
\hline 10 & Grenache & 13 & 24.9 & $3 \%$ & 31 & Chenin Blanc & 1 & 0.6 & $0.1 \%$ \\
\hline 11 & Sangiovese & 6 & 19.1 & $2 \%$ & 32 & Muller Thurgua & 2 & 0.6 & $0.1 \%$ \\
\hline 12 & Viognier & 13 & 18.2 & $2 \%$ & 33 & Carmenere & 1 & 0.5 & $0.1 \%$ \\
\hline 13 & Tempranillo & 10 & 17.2 & $2 \%$ & 34 & Gamay Noir & 1 & 0.5 & $0.1 \%$ \\
\hline 14 & Gruner Veltliner & 5 & 16.6 & $2 \%$ & 35 & Arneis & 1 & 0.4 & $0.04 \%$ \\
\hline 15 & Barbera & 10 & 16.4 & $2 \%$ & 36 & Marsanne & 2 & 0.3 & $0.03 \%$ \\
\hline 16 & Cabernet Franc & 5 & 14.0 & $1 \%$ & 37 & Tocai Fruilano & 1 & 0.2 & $0.02 \%$ \\
\hline 17 & Nebbiolo & 8 & 13.8 & $1 \%$ & 38 & Aglianico & 1 & $<1$ & - \\
\hline 18 & Sauvignon Blanc & 9 & 11.2 & $1 \%$ & 39 & Cinsau & 1 & $<1$ & - \\
\hline 19 & Albarino & 2 & 9.0 & $1 \%$ & 40 & Petite Verdot & 1 & $<1$ & - \\
\hline 20 & Dolcetto & 8 & 8.1 & $1 \%$ & 41 & Semillon & 1 & $<1$ & - \\
\hline 21 & Petite Sirah & 3 & 5.5 & $1 \%$ & & Total Estimated Ac & & & \\
\hline
\end{tabular}


Appendix B - 5. Grape variety estimations separated by each AVA. There are 34 varieties in the Columbia Gorge AVA and 25 in the Columbia Valley AVA. Generally cool (early) varietal grapes are more common in the Columbia Gorge AVA, and warm varietals are more common in the Columbia Valley AVA. Pinot Noir is the dominant variety in both AVAs.

\begin{tabular}{|c|c|c|c|c|c|c|c|c|c|}
\hline \multicolumn{5}{|c|}{ Columbia Gorge AVA } & \multicolumn{5}{|c|}{ Columbia Valley AVA } \\
\hline & Grape Variety & Acreage & $\begin{array}{l}\% \text { of total } \\
\text { estimated } \\
\text { acreage }\end{array}$ & $\begin{array}{c}\text { \# of } \\
\text { vineyard } \\
\text { plantings }\end{array}$ & & Grape Variety & Acreage & $\begin{array}{l}\% \text { of total } \\
\text { estimated } \\
\text { acreage }\end{array}$ & $\begin{array}{c}\text { \# of } \\
\text { vineyard } \\
\text { plantings }\end{array}$ \\
\hline 1 & Pinot Noir & 157 & $30 \%$ & 29 & 1 & Pinot Noir & 139 & $32 \%$ & 5 \\
\hline 2 & Chardonnay & 70 & $13 \%$ & 15 & 2 & Syrah & 55 & $13 \%$ & 13 \\
\hline 3 & Pinot Gris & 57 & $11 \%$ & 19 & 3 & Merlot & 41 & $9 \%$ & 8 \\
\hline 4 & Gewurztraminer & 54 & $10 \%$ & 12 & 4 & Zinfandel & 40 & $9 \%$ & 8 \\
\hline 5 & Riesling & 29 & $6 \%$ & 13 & 5 & Cabernet Sauvignon & 26 & $6 \%$ & 8 \\
\hline 6 & Gruner Veltliner & 17 & $3 \%$ & 5 & 6 & Sangiovese & 18 & $4 \%$ & 2 \\
\hline 7 & Albarino & 9 & $2 \%$ & 2 & 7 & Grenache & 16 & $4 \%$ & 3 \\
\hline 8 & Syrah & 32 & $6 \%$ & 19 & 8 & Viognier & 15 & $4 \%$ & 3 \\
\hline 9 & Zinfandel & 17 & $3 \%$ & 4 & 9 & Barbera & 13 & $3 \%$ & 5 \\
\hline 10 & Merlot & 15 & $3 \%$ & 10 & 10 & Nebbiolo & 13 & $3 \%$ & 4 \\
\hline 11 & Tempranillo & 13 & $3 \%$ & 8 & 11 & Cabernet Franc & 12 & $3 \%$ & 1 \\
\hline 12 & Grenache & 9 & $2 \%$ & 10 & 12 & Riesling & 12 & $3 \%$ & 6 \\
\hline 13 & Dolcetto & 7 & $1 \%$ & 6 & 13 & Pinot Gris & 8 & $2 \%$ & 1 \\
\hline 14 & Sauvignon Blanc & 4 & $1 \%$ & 6 & 14 & Sauvignon Blanc & 7 & $2 \%$ & 3 \\
\hline 15 & Cabernet Sauvignon & 3 & $1 \%$ & 4 & 15 & Chardonnay & 5 & $1 \%$ & 3 \\
\hline 16 & Barbera & 3 & $1 \%$ & 5 & 16 & Petite Sirah & 4 & $1 \%$ & 1 \\
\hline 17 & Viognier & 3 & $1 \%$ & 9 & 17 & Tempranillo & 4 & $1 \%$ & 2 \\
\hline 18 & Zweigelt & 3 & $0.5 \%$ & 2 & 18 & Malbec & 2 & $1 \%$ & 5 \\
\hline 19 & Lemberger & 3 & $0.5 \%$ & 1 & 19 & Dolcetto & 2 & $0.3 \%$ & 2 \\
\hline
\end{tabular}

$\bar{N}$ 
Appendix B - 5. Grape variety estimations separated by each AVA. There are 34 varieties in the Columbia Gorge AVA and 25 in the Columbia Valley AVA. Generally cool (early) varietal grapes are more common in the Columbia Gorge AVA, and warm varietals are more common in the Columbia Valley AVA. Pinot Noir is the dominant variety in both AVAs.

\begin{tabular}{|c|c|c|c|c|c|c|c|c|c|}
\hline \multicolumn{5}{|c|}{ Columbia Gorge AVA } & \multicolumn{5}{|c|}{ Columbia Valley AVA } \\
\hline & Grape Variety & Acreage & $\begin{array}{l}\% \text { of total } \\
\text { estimated } \\
\text { acreage }\end{array}$ & $\begin{array}{c}\text { \# of } \\
\text { vineyard } \\
\text { plantings }\end{array}$ & \multicolumn{2}{|c|}{ Grape Variety } & Acreage & $\begin{array}{c}\% \text { of total } \\
\text { estimated } \\
\text { acreage }\end{array}$ & \multirow{2}{*}{$\begin{array}{c}\text { \# of } \\
\text { vineyard } \\
\text { plantings } \\
0\end{array}$} \\
\hline 20 & Cabernet Franc & 2 & $0.4 \%$ & 4 & 20 & Muscat & 1 & $0.2 \%$ & \\
\hline 21 & Malbec & 2 & $0.3 \%$ & 1 & 21 & Mourvedre & 1 & $0.2 \%$ & 0 \\
\hline 22 & Primativo & 1 & $0.2 \%$ & 3 & 22 & Symphony & 1 & $0.2 \%$ & 1 \\
\hline 23 & Petite Sirah & 1 & $0.2 \%$ & 2 & 23 & Carmenere & 0.5 & $0.1 \%$ & 1 \\
\hline 24 & Sangiovese & 1 & $0.2 \%$ & 4 & 24 & Cinsault & $<1.0$ & & 0 \\
\hline 25 & Pinot Blanc & 1 & $0.2 \%$ & 2 & 25 & Petite Verdot & $<1.0$ & & 1 \\
\hline 26 & Roussanne & 1 & $0.2 \%$ & 2 & \multicolumn{2}{|c|}{ Total Estimated Acreage } & 435.76 & & \\
\hline 27 & Chenin Blanc & 0.6 & $0.1 \%$ & 1 & & & & & \\
\hline 28 & Nebbiolo & 0.6 & $0.1 \%$ & 4 & & & & & \\
\hline 29 & Muller Thurgua & 0.6 & $0.1 \%$ & 2 & & & & & \\
\hline 30 & Gamay Noir & 0.5 & $0.1 \%$ & 1 & & & & & \\
\hline 31 & Arneis & 0.4 & $0.1 \%$ & 1 & & & & & \\
\hline 32 & Muscat & 0.3 & $0.05 \%$ & 5 & & & & & \\
\hline 33 & Marsanne & 0.3 & $0.05 \%$ & 2 & & & & & \\
\hline 34 & Tocai Fruilano & 0.2 & $0.03 \%$ & 1 & & & & & \\
\hline 35 & Aglianico & $<1.0$ & - & 1 & & & & & \\
\hline 36 & Semillon & $<1.0$ & - & 1 & & & & & \\
\hline \multicolumn{5}{|c|}{517.64} & & & & & \\
\hline
\end{tabular}




\section{Appendix C: Vineyard Statistics}

Appendix C- 1. Statistics for the CGWR (82 Vineyards and 362 Vineyard Blocks).

\begin{tabular}{|c|c|c|c|c|c|}
\hline & Minimum & Maximum & SUM & Mean & St. Dev. \\
\hline Vineyard Acres & 0.5 & 297.0 & 1268.0 & 23.2 & 32.6 \\
\hline Vineyard Hectares & 0.2 & 120.2 & 513.0 & 9.4 & 13.2 \\
\hline Vineyard Block Acres & 0.0 & 266.0 & & 3.4 & 14.1 \\
\hline Vineyard Block Hectares & 0.0 & 107.6 & & 1.4 & 5.7 \\
\hline Elevation $(\mathrm{m})$ & 28.9 & 548.3 & & 239.3 & 115.7 \\
\hline Elevation (ft) & 94.7 & 1798.9 & & 785.1 & 381.1 \\
\hline Slope (degrees) & 0.0 & 31.0 & & 7.1 & 4.2 \\
\hline Slope (percent rise) & 0.0 & 0.6 & & 0.1 & 0.1 \\
\hline Annual Precip. (cm) & 27.5 & 95.3 & & 37.7 & 5.3 \\
\hline Annual Precip. (inches) & 10.8 & 37.5 & & 14.9 & 2.1 \\
\hline Growing Season Precip. (cm) & 1.1 & 3.4 & & 2.2 & 0.7 \\
\hline $\begin{array}{c}\text { Growing Season Precip. } \\
\text { (inches) }\end{array}$ & 0.4 & 1.3 & & 0.9 & 0.3 \\
\hline GST (Celsius) & 13.7 & 17.7 & & 15.6 & 6.7 \\
\hline GST (Farenheit) & 56.7 & 63.9 & & $60.1 \mathrm{C}$ & 22.3 \\
\hline GDD (Celcius) & 871 & 1664 & & 1233 & 209 \\
\hline \multirow{4}{*}{$\begin{array}{c}\text { GDD(Farenheit) } \\
\text { Curvature } \\
\text { Aspect }\end{array}$} & 1567 & 2994 & & 2226 & 379 \\
\hline & $99.9 \%$ Flat & $0.1 \%$ Concave & \multirow{3}{*}{\multicolumn{2}{|c|}{$\begin{array}{c}14.4 \% \text { South } \\
4.1 \% \text { Northwest }\end{array}$}} & \\
\hline & $29.4 \%$ East & $25.1 \%$ Southeast & & & $10 \%$ Southwest \\
\hline & 9.1\% West & $4.8 \%$ North & & & $3.3 \%$ Northeast \\
\hline Winkler Regions (GDD) & Region Ib (54\%) & Region Ia (27\%) & \multicolumn{2}{|c|}{ Region II (20\%) } & \\
\hline Climatic Regimes (GST) & Intermediate $(60 \%)$ & Cool $(26 \%)$ & \multicolumn{2}{|c|}{ Warm $(9 \%)$} & Warm $(1 \%)$ \\
\hline
\end{tabular}


Appendix C- 2 Statistics for Columbia Valley (CV) AVA (24 Vineyards and 139 Vineyard Blocks)

\begin{tabular}{|c|c|c|c|c|c|}
\hline & Minimum & Maximum & SUM & Mean & St. Dev. \\
\hline Vineyard Acres & 1.2 & 297.0 & 667.5 & 34.4 & 46.4 \\
\hline Vineyard Hectares & 0.5 & 120.2 & 270.1 & 13.9 & 18.8 \\
\hline Vineyard Block Acres & 0.0 & 266.0 & & 4.8 & 22.5 \\
\hline Vineyard Block Hectares & 0.0 & 107.6 & & 1.9 & 9.1 \\
\hline Elevation $(\mathrm{m})$ & 51.3 & 380.3 & & 178.2 & 89.9 \\
\hline Elevation (ft) & 168.3 & 1247.9 & & 584.7 & 331.9 \\
\hline Slope (degrees) & 0.0 & 30.1 & & 7.4 & 4.3 \\
\hline Slope (percent rise) & $0.0 \%$ & $58.0 \%$ & & $13.2 \%$ & $7.7 \%$ \\
\hline Annual Precip. (cm) & 27.5 & 47.0 & & 37.7 & 5.3 \\
\hline Annual Precip. (inches) & 10.8 & 18.5 & & 14.9 & 2.1 \\
\hline Growing Season Precip. (cm) & 1.3 & 3.4 & & 2.3 & 0.6 \\
\hline Growing Season Precip. (inches) & 0.5 & 1.3 & & 0.9 & 0.2 \\
\hline GST (Celsius) & 15.0 & 17.7 & & 16.6 & 7.3 \\
\hline GST (Farenheit) & 59.0 & 63.9 & & 61.8 & 22.6 \\
\hline GDD (Celcius) & 1116 & 1664 & & 1187 & 181.8 \\
\hline GDD (Farenheit) & 2008 & 2994 & & 2577 & 261.7 \\
\hline Curvature & $99.9 \%$ Flat & $0.1 \%$ Concave & \multirow{4}{*}{\multicolumn{3}{|c|}{$\begin{array}{l}\text { West }(8.2 \%) \\
\text { North }(2.0 \%)\end{array}$}} \\
\hline Aspect & East $(41.2 \%)$ & Southeast $(23.7 \%)$ & & & \\
\hline & Southwest (6.1\%) & Northwest (3.4\%) & & & \\
\hline Winkler Regions (GDD) & Region Ib (70.3\%) & Region II (29.6\%) & & & \\
\hline Climatic Regimes (GST) & Intermediate $(77.2 \%)$ & Warm $(16.5 \%)$ & \multicolumn{3}{|c|}{ Intermediate-Warm (6.3\%) } \\
\hline
\end{tabular}

岕 
Appendix C- 3. Statistics for the Columbia Gorge AVA (56 Vineyards and 222 Vineyard Blocks)

\begin{tabular}{|c|c|c|c|c|c|}
\hline & Minimum & Maximum & SUM & Mean & St. Dev. \\
\hline Vineyard Acres & 0.5 & 57.7 & 579.2 & 16.2 & 16.2 \\
\hline Vineyard Hectares & 0.2 & 23.3 & 234.4 & 6.6 & 6.6 \\
\hline Vineyard Block Acres & 0.0 & 15.2 & & 2.6 & 2.4 \\
\hline Vineyard Block Hectares & 0.0 & 6.1 & & 1.1 & 1.0 \\
\hline Elevation $(\mathrm{m})$ & 28.9 & 548.3 & & 277.4 & 113.7 \\
\hline Elevation (ft) & 94.7 & 1798.9 & & 910.0 & 373.0 \\
\hline Slope (degrees) & 0.0 & 31.0 & & 6.9 & 4.1 \\
\hline Slope (percent rise) & 0.0 & 0.6 & & 0.1 & 0.1 \\
\hline Annual Precip. (cm) & 45.1 & 95.3 & & 72.2 & 14.0 \\
\hline Annual Precip. (inches) & 17.8 & 37.5 & & 28.4 & 5.5 \\
\hline Growing Season Precip. (cm) & 1.8 & 3.4 & & 2.6 & 0.5 \\
\hline $\begin{array}{c}\text { Growing Season Precip. } \\
\text { (inches) }\end{array}$ & 0.7 & 1.3 & & 1.0 & 0.2 \\
\hline GST (Celsius) & 13.7 & 16.9 & & 15.0 & 6.3 \\
\hline GST (Farenheit) & 56.7 & 62.4 & & 59.0 & 22.0 \\
\hline GDD (Celcius) & 871 & 1480 & & 1262 & 220 \\
\hline GDD(Farenheit) & 1568 & 2663 & & 2007 & 255 \\
\hline Curvature & $100 \%$ Flat & & & \multirow{5}{*}{$\begin{array}{l}\text { SW }(14.4 \%) \\
\text { NE }(4.3 \%)\end{array}$} & \\
\hline \multirow[t]{2}{*}{ Aspect } & Southeast $(26.6 \%)$ & South (15.9\%) & East $(15.9 \%)$ & & \\
\hline & West (10.1\%) & North $(8.0 \%)$ & NW $(4.9 \%)$ & & \\
\hline Winkler Regions (GDD) & Cool $(56 \%)$ & Intermediate $(41 \%)$ & Cool-Inter. (3\%) & & \\
\hline Climatic Regimes (GST) & Region Ia (57\%) & Region Ib (35\%) & Region II (8\%) & & \\
\hline
\end{tabular}

$\tilde{\omega}$ 
Appendix C- 4. Statistics for Vineyards Outside the CGWR: 13 Vineyard Blocks (1.5 Vineyards) Outside of CGWR

\begin{tabular}{|c|c|c|c|c|c|}
\hline & Minimum & Maximum & SUM & Mean & St. Dev. \\
\hline Vineyard Acres & 11.3 & 16.7 & 20.6 & 15.8 & 1.9 \\
\hline Vineyard Hectares & 4.6 & 6.7 & 8.3 & 6.4 & 0.8 \\
\hline Vineyard Block Acres & 0.1 & 4.8 & & 1.6 & 1.2 \\
\hline Vineyard Block Hectares & 0.1 & 2.0 & & 0.6 & 0.5 \\
\hline Elevation $(\mathrm{m})$ & 325.0 & 406.8 & & 367.4 & 22.4 \\
\hline Elevation (ft) & 1066.4 & 1334.5 & & 1205.5 & 73.6 \\
\hline Slope (degrees) & 1.5 & 19.0 & & 9.1 & 3.1 \\
\hline Slope (percent rise) & 0.0 & 0.3 & & 0.2 & 0.1 \\
\hline Annual Precip. (cm) & 35.9 & 87.0 & & 43.7 & 18.0 \\
\hline Annual Precip. (inches) & 10.8 & 18.5 & & 14.9 & 2.1 \\
\hline Growing Season Precip. (cm) & 1.7 & 3.1 & & 1.9 & 0.5 \\
\hline $\begin{array}{c}\text { Growing Season Precip. } \\
\text { (inches) }\end{array}$ & 0.7 & 1.2 & & 0.8 & 0.2 \\
\hline GST (Celsius) & 14.2 & 15.6 & & 15.4 & 6.7 \\
\hline GST (Farenheit) & 57.6 & 60.1 & & 59.7 & 22.2 \\
\hline GDD (Celcius) & 947 & 1217 & & 1183.8 & 75.4 \\
\hline GDD(Farenheit) & 1705 & 2190 & & 2130.8 & 135.7 \\
\hline Curvature & $100 \%$ Flat & & & & \\
\hline Aspect & Northwest $(54.7 \%)$ & North $(17.3 \%)$ & Southwest $(9.8 \%)$ & South $(9.3 \%)$ & West $(8.9 \%)$ \\
\hline Winkler Regions (GDD) & Region Ib (56\%) & \multicolumn{2}{|c|}{ Region II (44\%) } & & \\
\hline Climatic Regimes (GST) & Cool $(19 \%)$ & \multicolumn{2}{|c|}{ Intermediate $(81 \%)$} & & \\
\hline
\end{tabular}




\section{Appendix D: Soil pit field notes and descriptions}

Appendix D - 1.There are 15 map units at vineyard sites that classify as complex soils. All of these soils combined account for $3 \%$ of the total growing acreage

\begin{tabular}{cccc}
\hline Map Unit Name & Hectares & Acres & \% of growing acreage \\
\hline Rock outcrop-Haploxerolls complex & 3.4 & 8.4 & $1 \%$ \\
Stacker-Horseflat complex & 2.4 & 5.8 & $0.5 \%$ \\
Hesslan-Skyline complex & 2.2 & 5.6 & $0.4 \%$ \\
Gunn-Galiente complex & 2.0 & 4.9 & $0.4 \%$ \\
Cherryhill-Rock outcrop complex & 1.8 & 4.6 & $0.4 \%$ \\
Wamic-Skyline complex & 1.8 & 4.5 & $0.4 \%$ \\
Rock outcrop-Xeropsamments complex & 1.5 & 3.7 & $0.3 \%$ \\
Stacker-Swalecreek-Horseflat complex & 1.0 & 2.6 & $0.2 \%$ \\
Rock outcrop-Rubble land-Haploxerolls complex & 0.4 & 1.1 & $0.1 \%$ \\
Quincy-Rock outcrop complex & 0.3 & 0.7 & $0.1 \%$ \\
Dallesport-Rock outcrop complex & 0.2 & 0.5 & $0.04 \%$ \\
Rock outcrop-Bodell-Bald complex & 0.2 & 0.4 & $0.03 \%$ \\
Xerorthents-Rock outcrop complex & 0.1 & 0.3 & $0.02 \%$ \\
Skyline-Hesslan complex & 0.1 & 0.3 & $0.02 \%$ \\
Fluventic Haploxerolls-Riverwash complex & 0.02 & 0.04 & $0.003 \%$ \\
\hline
\end{tabular}


Appendix D - 2. Field Classifications differed from the NRCS classifications at four vineyard sites. These 15 soil pits represent the most common soil series at vineyards in the CGWR.

\begin{tabular}{|c|c|c|c|c|}
\hline Soil Pit ID & Field Classification & NRCS Classification & $\begin{array}{l}\text { Recommended } \\
\text { Soil Series }\end{array}$ & $\mathrm{pH}$ \\
\hline Marchesi Vineyard \#1 & Ultic Haploxerolls & Ultic Argixerolls & Rockford & A- $6.0 ; \mathrm{Btj}-6.5$ \\
\hline Marchesi Vineyard \#2 & Ultic Haploxerolls & Ultic Haploxerolls & Rockford & A- $6.0 ; \mathrm{Bw}-6.5$ \\
\hline Phelps Creek Vineyard & Ultic Haploxeralfs & Ultic Haploxeralfs & Oak Grove & A-6.0; Bt-6.0 \\
\hline Wy'East Vineyard & Typic Haploxerolls & Typic Haploxerolls & Culbertson & A-6.3; Bw-6.6 \\
\hline Blue Chip Farm Vineyard & Ultic Haploxeralfs & Ultic Haploxeralfs & Hood & A-7.2: Bt-7.2 \\
\hline Underwood Mounain Vineyard \#1 & Vitrandic Haploxeralfs & Vitrandic Haploxeralfs & Underwood & A1-5.9; A2-6.0; Bt-6.4 \\
\hline Underwood Mountain Vineyard \#2 & Humic Vitrixerand & Humic Vitrixerand & Chemawa & A1-6.1; A2-6.4; Bw-6.5 \\
\hline $\begin{array}{c}\text { Cor Cellars Vineyard } \\
\text { Parkers Vineyard (Memaloose }\end{array}$ & Ultic Argixerolls & Ultic Argixerolls & Balake & A-6.1; Btj-6.5 \\
\hline Winery) & Ultic Argixerolls & Ultic Haploxeralfs & Gunn & A-6.3; Bt-6.3 \\
\hline Graves Vineyard & Typic Xeropsamments & Typic Xeropsamments & Ewall & A-7.5; A2-7.4 \\
\hline Bethany in the Gorge Vineyard & Typic Haploxerept & Typic Haploxerolls & Dallesport & $\mathrm{A}-7.6 ; \mathrm{Bw}-7.0$ \\
\hline Chuckar Ridge Vineyard & Typic Haploxeralf & Ultic Argixerolls & Fisherhill & A-6.9; Bt-6.8 \\
\hline Sunshine Mountain Vineyard & Calcic Haploxerolls & Typic Haploxerolls & Chard & A-5.8; Bw-5.9; Bk-7.2 \\
\hline HD LLC (Hillside Vineyard) & Typic Haploxerept & Typic Haploxerolls & Duart & A-6.9; Bw-7.1; Btj-7.1 \\
\hline Dry Hollow Vineyard & Pertrocalcic Calcixerpet & Ultic Argixeralf & $\mathrm{n} / \mathrm{a}$ & A-6.7; Bk-6.5 \\
\hline
\end{tabular}


Appendix D - 3. Hood River soil sub-region: Marchesi Vineyard \#1

Field Classification: Ultic Haploxeroll

Location:

Elevation:

Hood River County, Oregon;

Topography: 193 meters (634 feet)

Northeast facing, $1^{\circ}$ slope

(United States Geological

Survey2013b)

Drainage: Well-drained

Native Vegetation: Ponderosa pine \& Douglas fir (Soil Survey Staff, 2012a)

Parent material: $\quad$ Valley-filling outwash gravel (McClaughry et al., 2012b), alluvium and glacial outwash (Soil Survey Staff, 2012a)

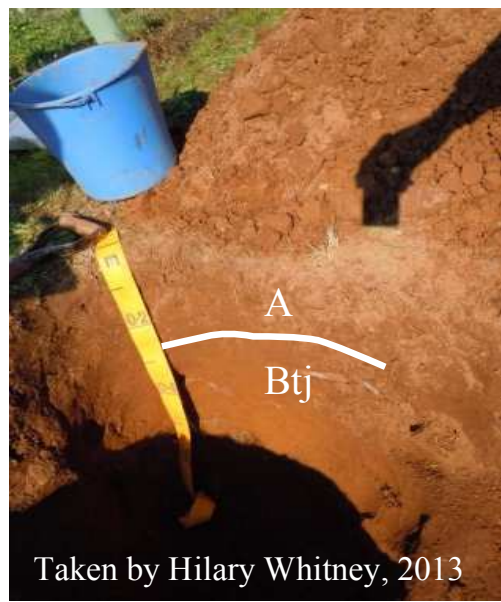

Described by:

H. Whitney, S. Burns \& S. Icefire, October 24, 2013

Remarks

\section{Soil Pit Description}

The NRCS Soil Survey mapped this site as the Van Horn Series (Ultic Argixeroll) (Soil Survey Staff, 2012a). Field classification is not in agreement with the NRCS classification, and is likely part of the nearby Rockford Series. Primary reasons for this reclassification is the lack of an argillic horizon and the presence of gravels in the Bw-horizon

0-30 cm (0-12 in.). Dark brown (10YR 3/3) when moist; (10YR 4/3) when dry; sandy loam; weak fine subangular blocky structure; friable (moist), slightly hard (dry), nons ticky and nonplastic (wet); $\mathrm{pH}=6.0$; abrupt and smooth boundary; no clay films observed.

$\mathrm{Bt}$ 30-65+ cm (12-26+ in.). Dark yellowish brown (10YR 3/4) when moist; yellowish brown (10YR 5/4) when dry; sandy loam; moderate coarse subangular blocky structure; friable (moist), slightly hard (dry), slightly sticky and slightly plastic (wet); $40 \%$ gravel; $\mathrm{pH}=6.5$; boundary unknown as bottom of horizon was not reached; very few clay films observed. 
Appendix D - 3. Hood River soil sub-region: Marchesi Vineyard \#2

Field Classification: Ultic Haploxeroll

Location: Hood River County, Oregon;

Elevation: $\quad 187$ meters (612 feet)

Topography: $\quad$ Northeast facing, $0.4-0.8^{\circ}$

slopes (United States

Geological Survey2013b)

Drainage: Well-drained

Native Vegetation: Ponderosa pine, Douglas fir, Oregon white oak, forbs and shrubs (Soil Survey Staff, 2012a)

Parent material: Valley filling outwash gravels (McClaughry et al., 2012b)

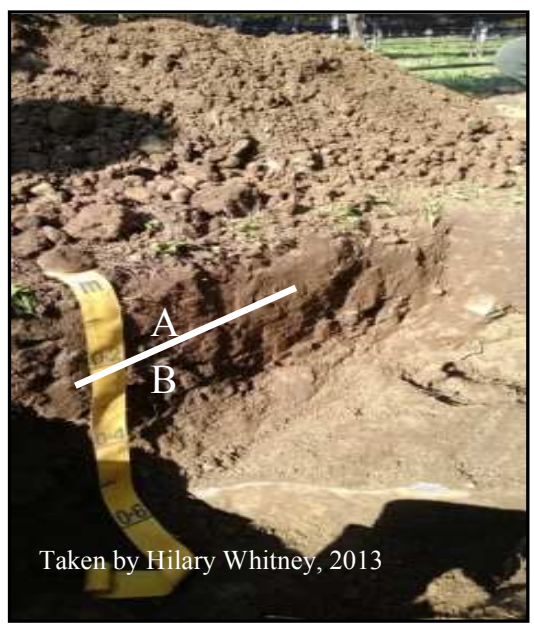

Described by:

Remarks

H. Whitney, S. Burns, T. Linde, October 24, 2013

The NRCS Soil Survey mapped this site as the Rockford Series (Ultic Haploxeroll) (Soil Survey Staff, 2012a). Field classification is in agreement with the NRCS classification. Missoula Flood deposits could likely be the parent material of this site as the boundaries mapped by McClaughry et al., 2012 were very close to this site.

Soil Pit Description

A

$\mathrm{Bw}$
0-30 cm (0-12 in.). Dark brown (10YR 3/3) when moist; (10YR 4/3) when dry; sandy loam; weak fine subangular blocky structure; friable (moist), slightly hard (dry), nonsticky and nonplastic (wet); $\mathrm{pH}=6.0$; abrupt and smooth boundary; no clay films observed.

30-65+ cm (12-26+ in.). Dark yellowish brown (10YR 3/4) when moist; yellowish brown (10YR 5/4) when dry; sandy loam; moderate coarse subangular blocky structure; friable (moist), slightly hard (dry), slightly sticky and slightly plastic (wet); $40 \%$ gravel; $\mathrm{pH}=6.5$; boundary unknown as bottom of horizon was not reached; very few clay films observed. 
Appendix D - 3. Hood River soil sub-region: Phelps Creek Vineyard

Field Classification: Ultic Haploxeralf

Location:

Elevation:

Topography:

Hood River County, Oregon; 302 meters (992 feet).

Southeast facing, $6.5^{\circ}$ slope

(United States Geological

Survey, 2013b)

Drainage: Well-drained

Native Vegetation: Douglas fir, ponderosa pine, Oregon white oak, Pacific madrone, poison oak and grasses (Soil Survey Staff, 2012a)

Parent material: $\quad$ Quaternary Basalt (McClaughry et al., 2012b), alluvium and clayey mudflow deposits (Soil Survey Staff, 2012a)

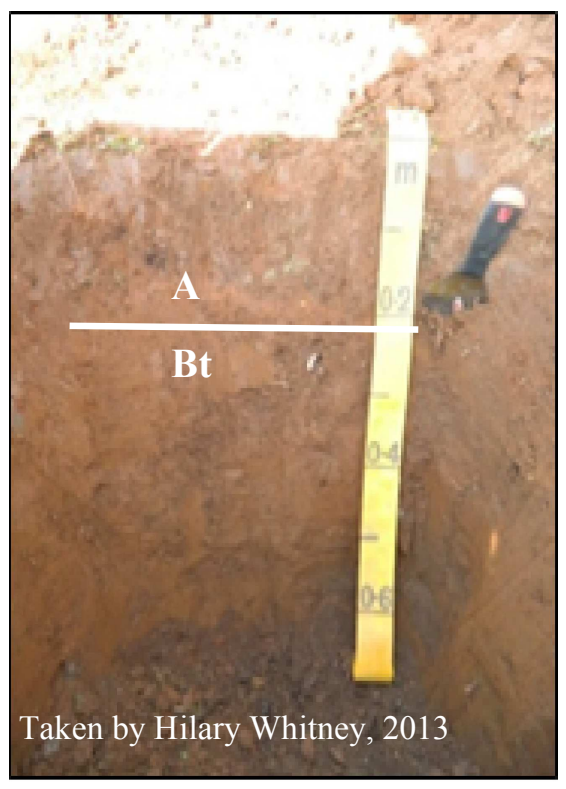

Described by: Remarks

H. Whitney, S. Burns, October 24, 2013

The NRCS Soil Survey mapped this site as the Oak Grove Series (Ultic Palexeralf) (Soil Survey Staff, 2012a). Field classification is not in agreement with the NRCS classification, and is likely part of the nearby Veneta Series. Primary reasons for this reclassification are the lack of a well-established argillic horizon. The Oak Grove Series is thought to have similar soil horizons and structure to the Willakenzie Series in the Willamette Valley.

\section{Soil Pit Description}

0-30 cm (0-12 in.). Dark brown (10YR 3/3) when moist; (10YR 4/3) when dry; sandy loam; weak fine subangular blocky structure; friable (moist), slightly hard (dry), nonsticky and nonplastic (wet); $\mathrm{pH}=6.0$; abrupt and smooth boundary; no clay films observed.

$\mathrm{Bw}$

30-65+ cm (12-26+ in.). Dark yellowish brown (10YR 3/4) when moist; yellowish brown (10YR 5/4) when dry; sandy loam; moderate coarse subangular blocky structure; friable (moist), slightly hard (dry), slightly sticky and slightly plastic (wet); $40 \%$ gravel; $\mathrm{pH}=6.5$; boundary unknown as bottom of horizon was not reached; very few clay films observed. 
Appendix D - 3. Hood River soil sub-region: Phelps Creek Vineyard

Field Classification: Ultic Haploxeralf

Location:

Hood River County, Oregon;

Elevation:

302 meters (992 feet).

Topography:

Southeast facing, $6.5^{\circ}$ slope (United States Geological Survey, 2013b)

Drainage:

Well-drained

Native Vegetation: Douglas fir, ponderosa pine, Oregon white oak, Pacific madrone, poison oak and grasses (Soil Survey Staff, 2012a)

Parent material: $\quad$ Quaternary Basalt

(McClaughry et al., 2012b),

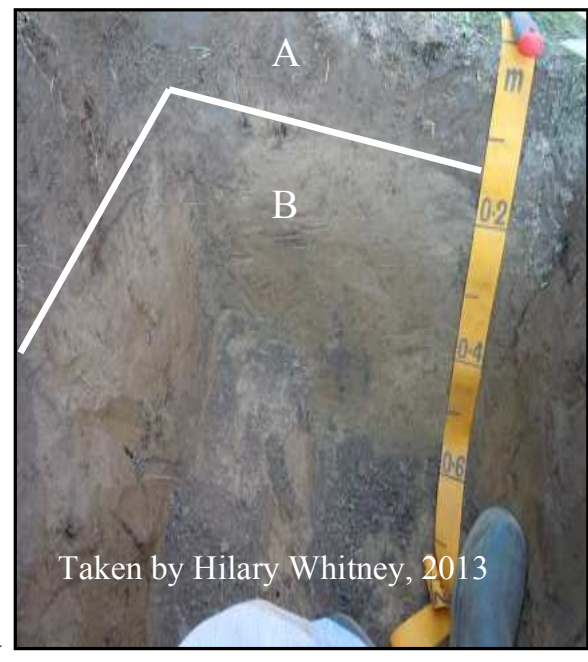
alluvium and clayey mudflow deposits (Soil Survey Staff, 2012a)

Described by: $\quad$ H. Whitney, S. Burns, October 24, 2013

Remarks The NRCS Soil Survey mapped this site as the Oak Grove Series (Ultic Palexeralf) (Soil Survey Staff, 2012a). Field classification is not in agreement with the NRCS classification, and is likely part of the nearby Veneta Series. Primary reasons for this reclassification are the lack of a well-established argillic horizon. The Oak Grove Series is thought to have similar soil horizons and structure to the Willakenzie Series in the Willamette Valley.

\section{Soil Pit Description}

A

0-30 cm (0-12 in.). Dark brown (10YR 3/3) when moist; (10YR 4/3) when dry; sandy loam; weak fine subangular blocky structure; friable (moist), slightly hard (dry), nonsticky and nonplastic (wet); $\mathrm{pH}=6.0$; abrupt and smooth boundary; no clay films observed.

Bw 30-65+ cm (12-26+ in.). Dark yellowish brown (10YR 3/4) when moist; yellowish brown (10YR 5/4) when dry; sandy loam; moderate coarse subangular blocky structure; friable (moist), slightly hard (dry), slightly sticky and slightly plastic (wet); $40 \%$ gravel; $\mathrm{pH}=6.5$; boundary unknown as bottom of horizon was not reached; very few clay films observed. 
Appendix D - 3. Hood River soil sub-region: Wy'East Vineyard

Field Classification: Typic Haploxeroll

Location:

Elevation:

Hood River County, Oregon;

Topography:

517 meters $(1,696$ feet $)$

South-facing, $7.6^{\circ}$ slopes

(United States Geological

Survey, 2013b)

Drainage:

Well-drained

Native Vegetation:

Douglas fir, maple, willow and bunchgrasses (Soil Survey Staff, 2012a)

Parent material: $\quad$ Loess (Soil Survey Staff, 2012a), volcanic ash \& andesite colluvium

(McClaughry et al., 2012b)

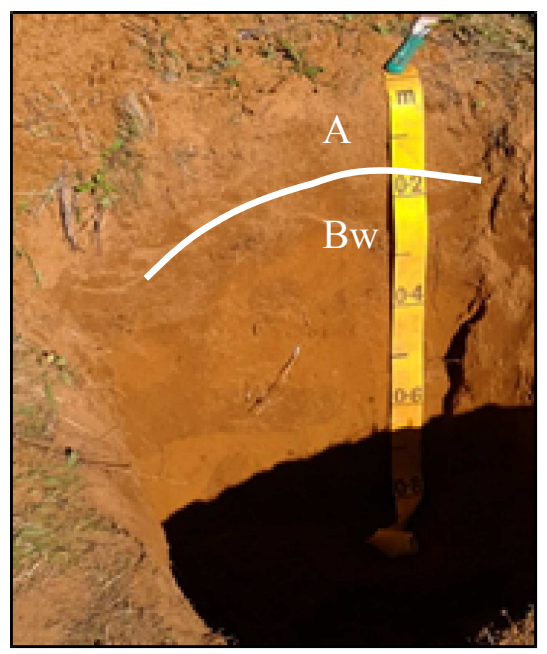

Described by:

H.Whitney, S.Burns, S. Icefire, A. Pillar, October 24, 2013

Remarks

The NRCS Soil Survey mapped this site as the Culbertson Series (Typic Haploxeroll) (Soil Survey Staff, 2012a). Field classificatio is in agreement with the NRCS classification, and the A horizon varied in thickness.

\section{Soil Pit Description}

0-20 cm. Dark yellowish brown (10 YR 4/4) when moist; yellowish brown (10 YR 5/4) when dry; sandy loam; weak fine subangular blocky structure; friable (moist), nonsticky and nonplastic (wet); abundant krotovinas; $\mathrm{pH}=6.3$.

$\mathrm{Bt}$

20-80+ cm. Dark yellowish brown (10 YR 4/6) when moist; dark yellowish brown (10 YR 4/6) when dry; sandy loam; weak fine subangular block structure; friable (moist), slightly sticky and slightly plastic (wet); $\mathrm{pH}=6.6$; boundary unknown as bottom of horizon was not reached. 
Appendix D - 3. Underwood Mountain sub-region: Underwood Mountain Vineyard \#1 Field Classification: Vitrandic Haploxeralfs

Location:

Elevation:

Topography:

Drainage:

Native Vegetation:

Described by:

Remarks

\section{Soil Pit Description}

A1

A2

$\mathrm{Bt}$
Skamania County, Washington; 289 meters (949 feet)

Southeast-facing, $5^{\circ}$ slope (United States Geological

Survey, 2013b)

Well-drained

Douglas-fir, grand fir, falsesolomon's-seal (Washington

Department of Natural

Resources Staff, 2010)

Mountain (Washington

Department of Natural

Resources Staff, 2010) mixed

with volcanic ash (Soil

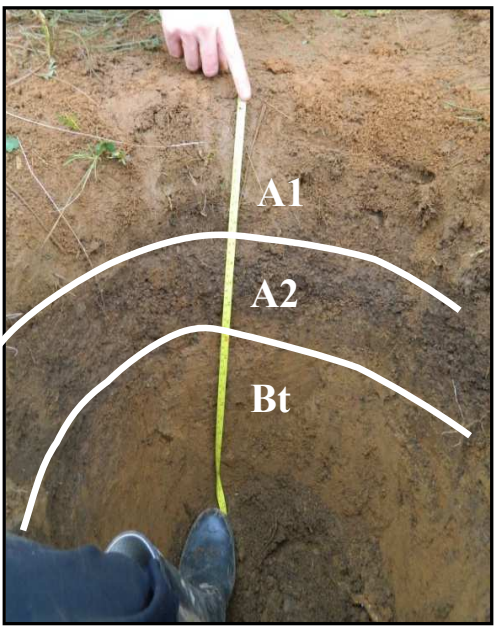

Survey Staff, 2012b)

H.Whitney, S.Burns, S. Icefire, A. Pillar, October 24, 2013

The NRCS Soil Survey mapped this site as the Underwood

Series (Vitrandic Haploxeralfs) (Soil Survey Staff, 2012b). Field classification is in agreement with the NRCS classification.

0-16 cm. Dark brown (7.5 YR 3/4) primary color, strong brown (7.5 YR 4/6) secondary color when moist; brown (10YR 4/3) when dry; silty loam; moderate fine subangular blocky structure; very friable (moist), nonsticky and nonplastic (wet); mottles result in primary and secondary color differentiation, pisolites; $\mathrm{pH}=5.9$; abrupt smooth boundary.

16-29 cm. Dark brown (7.5 YR 3/3) primary color when moist, strong brown (7.5 YR 4/6) secondary color when moist; silty clay; dark yellowish brown (10YR 4/4) when dry; moderate fine subangular blocky structure; very friable (moist), nonsticky to slightly sticky and nonplastic (wet); mottles result in primary and secondary color differentiation; Iron concretions (pisolites) common except on west side of pit; $\mathrm{pH}=6.0$; abrupt smooth boundary.

29-60+ cm. Brown (7.5 YR 4/4) when moist; dark yellowish brown (10 YR 4/6) when dry; clay loam; weak fine subangular blocky structure; firm (moist); slightly sticky and slightly plastic (wet); few pisolites; $\mathrm{pH}=6.4$; boundary unknown as bottom of horizon was not reached. 
Appendix D - 3. Lyle soil sub-region: Parkers (Memaloose) Vineyard

Field Classification: Ultic Argixeroll

Location:

Hood River County,

Oregon;

Elevation:

297 meters (975 feet)

Topography:

Southwest-facing, $4^{\circ}$ slope

(United States Geological

Survey, 2013b)

Drainage:

Well-drained

Native Vegetation:

Ponderosa pine and grasses

(Soil Survey Staff, 2012b)

Parent material:

Loess mixed with

Pliocene basalt colluvium

(Washington Department

of Natural Resources Soil

Survey Staff, 2012b; Staff,

2010), above Missoula Floo

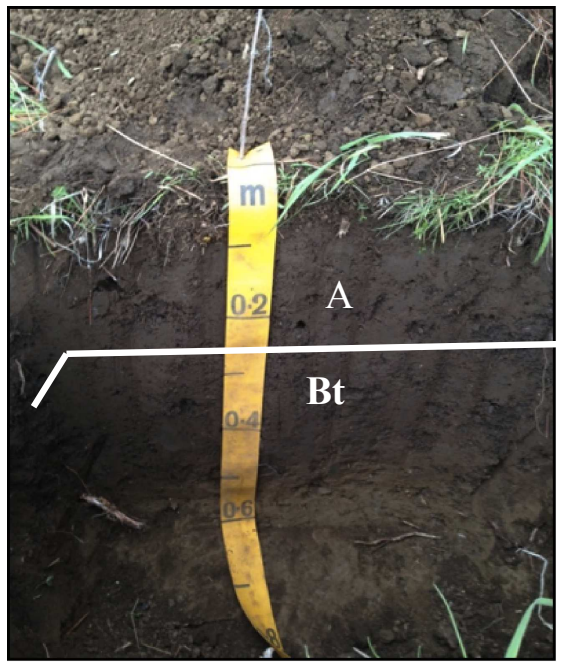

Described by:

(Benito and O'Connor,2003

Remarks

S. Burns, G. Ferrera, D. Demchak, T. Casey, November 11 ${ }^{\text {th }}, 2013$ The NRCS Soil Survey mapped this site as the Gunn Series (Ultic Haploxeralfs) (Soil Survey Staff, 2012b). Field classification is not in agreement with the NRCS classification. The only difference is a thicker A-horizon was described in the field, otherwise they are very similar. It is likely that this is still the Gunn Series. Field observations indicate a very dense, hard layer below 27 inches, likely very weathered basalt bedrock. From conversation with the resident, it was learned that a nearby structure required blasting to construct a shallow foundation.

\section{Soil Pit Description}

A

0-30 cm (0-12 in.). Dark brown (10YR 3/3) when moist; (10YR 4/3) when dry; sandy loam; weak fine subangular blocky structure; friable (moist), slightly hard (dry), nonsticky and nonplastic (wet); $\mathrm{pH}=6.0$; abrupt and smooth boundary; no clay films observed.

$\mathrm{Bt}$

30-65+ cm (12-26+ in.). Dark yellowish brown (10YR 3/4) when moist; yellowish brown (10YR 5/4) when dry; sandy loam; moderate coarse subangular blocky structure; friable (moist), slightly hard (dry), slightly sticky and slightly plastic (wet); $40 \%$ gravel; $\mathrm{pH}=6.5$; boundary unknown as bottom of horizon was not reached; very few clay films observed. 
Appendix D - 3. Lyle soil sub-region: Cor Cellars Winery and Vineyard

Field Classification: Ultic Argixeroll

Location:

Elevation:

Klickitat County, Washington;

Topography:

171 meters (561 feet)

South-facing, $3.4^{\circ}$ slope

(United State Geological

Drainage: Well-drained

Native Vegetation: Scrubby grassland, Oregon white Oak (Soil Survey Staff, 2012b)

Parent material: $\quad$ Loess (Soil Survey Staff, 2012b) overlying The Dalles

Formation (Washington

Department of Natural

Resources Staff, 2010). Soil

pit is below expected

Missoula Flood boundary.

Described by: $\quad$ S. Burns, E. Brown, T. Casey, November 11th, 2013

Remarks

The NRCS Soil Survey mapped this site as the Balake Series (Ultic Arigixeroll) (Soil Survey Staff, 2012b). Field classification is in agreement with the NRCS classification. This soil pit is very skeletal and contains a plow horizon (Ap).

\section{Soil Pit Description}

$\mathrm{O}$

1-0 cm (0.40-0 in.). Organic layer consisting of grass, litter, and decomposing litter.

Ap

0-19 cm (0-7 in.). Very dark grayish brown (10YR 3/2) when moist; dark grayish brown (10YR 4/2) when dry; sandy clay loam with less than $10 \%$ gravel; weak fine subangular blocky structure; very friable (moist), slightly sticky and slightly plastic (wet); $\mathrm{pH}=$ 6.1; clear straight boundary.

Btj $19+\mathrm{cm}(7+$ in.). Dark yellowish brown (10YR 3/4) when moist; dark yellowish brown (10YR 4/4) when dry; sandy clay loam with $50 \%$ gravel; moderate fine subangular blocky structure; friable (moist), slightly sticky and plastic (wet); $\mathrm{pH}=6.5$; boundary unknown as bottom of horizon was not reached; few faint clay films on ped faces. 
Appendix D - 3. Dallesport soil sub-region: Chuckar Ridge Vineyard

Field Classification: Typic Haploxeralf

Location:

Klickitat County,

Washington;

Elevation:

Topography:

299 meters (980 feet)

Drainage:

Southeast-facing, $6^{\circ}$ slope (Uni Geological Survey, 2013b)

Native Vegetation:

Well-drained

Parent material: $\quad$ Loess (Soil Survey Staff,

Scrubby grassland, Oregon

white oak 2012b) and Columbia River

Basalt (Washington

Department of Natural

Resources Staff, 2010)

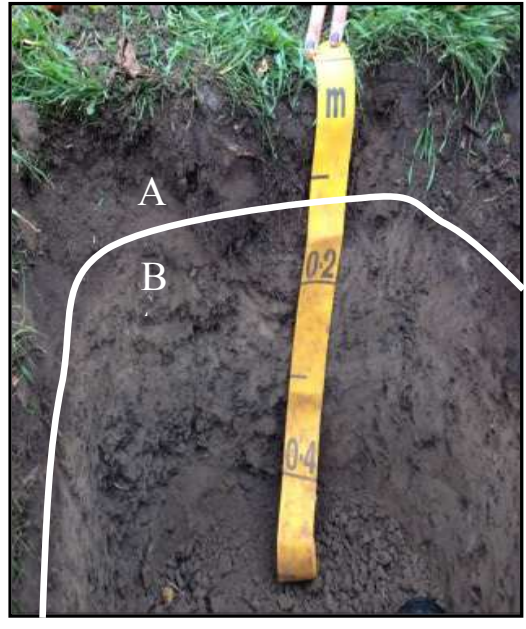

Described by:

S. Burns, E. Brown, H. Tolley, November 11th, 2013

Remarks

2013 The NRCS Soil Survey mapped this site as the Fisherhill

Series (Ultic Argixeroll) (Soil Survey Staff, 2012b). Field

classification is not in agreement with the NRCS classification.

Primary reasons for this reclassification was from the thickness of an A-horizon. If the A-horizon was thicker, then it would be classified as an Ultic Argixeroll The suggested reclassification for this soil is the Cherryhill Series (Soil Survey Staff, 2012b).

\section{Soil Pit Description}

$\mathrm{O}$

A

$\mathrm{Bt}$
3-0 cm (1-0 in.). Organic layer consisting of grass, litter, and decomposing litter.

0-13 cm (0-5 in.). Very dark brown (10YR 2/2) when moist; very dark gray (10YR 3/1) when dry; sandy clay loam; weak fine subangular blocky structure; very friable (moist), slightly sticky and plastic (wet); $\mathrm{pH}=6.9$; abrupt straight boundary.

13-22+ cm (6-9+ in.). Dark grayish brown (10YR 4/2) when moist; dark gray (10YR 4/1) when dry; silty clay loam; moderate fine angular blocky structure; extremely firm (moist), sticky and plastic (wet); abundant prominent clay films on ped faces; $\mathrm{pH}=6.8$; boundary unknown as bottom of horizon was not reached. 
Appendix D - 3. Dallesport soil sub-region: Bethany in the Gorge Vineyard

Field Classification: Typic Haploxerept

Location:

Elevation:

Topography:

Klickitat County, Washington; ، 159 meters (520 feet)

South-facing, $8.8^{\circ}$ slope (United States Geological

Survey, 2013b)

Drainage:

Well-drained

Native Vegetation:

Grasses, shrubs, Ponderosa pine (Soil Survey Staff, 2012b)

Parent material: $\quad$ Field observations indicate skeletal composition - many cobbles (6 in) and few boulders (12 in.) encountered

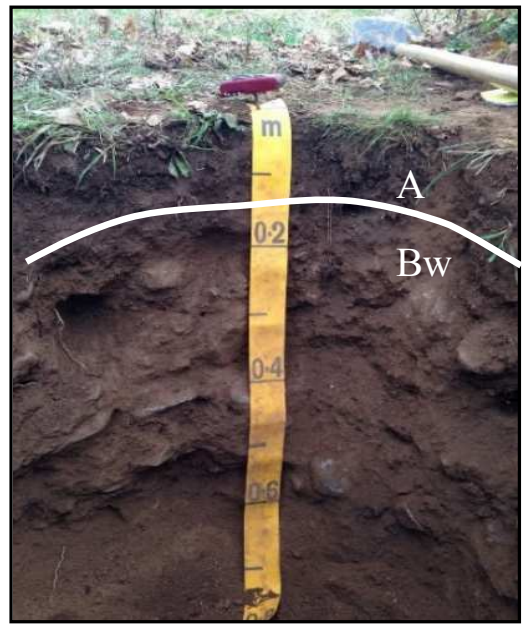
throughout horizons and are likely sourced from the Missoula Floods.

Described by: $\quad$ S. Burns, G. Ferreira, T. Casey, D. Demchak, November 11th, 2013.

Remarks

The NRCS Soil Survey mapped this site as the Dallesport Series (Typic Haploxeroll) (Washington Department of Natural Resources Staff, 2010). Field classification is not in agreement with the NRCS classification, although it is still likely part of the Dallesport Series. The soil series classification features a Mollic Epipedon where as a small ochric epipedon was described in the field.

\section{Soil Pit Description}

0-15 cm (0-6 in.). Brown (10YR 3/2) (dry); sandy loam; single grained fine subangular blocky structure; slightly hard (dry), friable (moist), non-sticky and slightly plastic (wet); few fine to medium roots; very few interstitial pores; $10 \%$ gravel; $\mathrm{pH}=7.6$; clear wavy boundary.

$\mathrm{Bw}$ 15-66+ cm (6-26 in.). Yellowish brown (10YR 4/3) (dry); sandy loam; single grained coarse subangular blocky structure; slightly hard (dry), friable (moist), non-sticky and slightly plastic (wet); very few roots; very few interstitial pores; $50 \%$ gravel; $\mathrm{pH}=7.0$. 
Appendix D - 3. Dallesport soil sub-region: Graves Vineyard

Field Classification: Typic Xeropsamment

Location:

Elevation:

Klickitat County, Washington;

Topography:

80 meters (262 feet)

Southwest-facing, $2^{\circ}$ slope

(United States Geological

Survey2013b)

Drainage: Well-drained

Native Vegetation: Bitterbrush, blue bunch wheatgrass and ponderosa pine (Soil Survey Staff, 2012b)

Parent material: $\quad$ Missoula Flood gravels, sand d (Washington Department of $\mathrm{Na}$ Resources Staff, 2010)

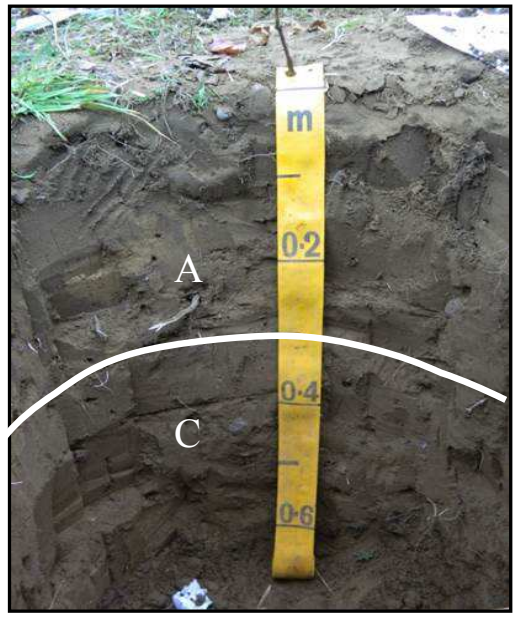

Described by: $\quad$ H. Hurtado, H. Whitney, D. Hansen, November 11, 2013

Remarks

The NRCS Soil Survey mapped this site as the Ewall Series (Typic Xeropsamment) (Soil Survey Staff, 2012b). Field classification is in agreement with the NRCS classification.

Soil Pit Description

A1 0-30 cm (0-11.8 in.). Dark brown (10 YR 3/3) moist; dark grayish brown (10 YR 4/2) dry; loamy sand; weak fine subangular blocky structure; very friable (moist), nonsticky and nonplastic (wet); $\mathrm{pH}=7.5$; diffuse wavy boundary.

30-67+ cm (11.8-26 in.) Dark yellowish brown (10 YR 3/4) when moist; dark yellowish brown (10 YR 3/4) when dry; loamy sand; weak fine subangular block structure; very friable (moist), nonsticky and nonplastic (wet); $\mathrm{pH}=7.4$; boundary unknown as bottom of horizon was not reached. 
Appendix D - 3. The Dalles soil sub-region: Hi Valley Vineyard (Dry Hollow Winery) Field Classification: Petrocalcic Calcixerept

Location:

Elevation:

Wasco County, Oregon

Topography: 338 meters (1109 feet)

Southeast-facing, $4.3^{\circ}$ slope (United States Geological Survey, 2013b)

Drainage: Well-drained

Native Vegetation: Ponderosa pine, Oregon white oak, bluebunch wheatgrass Parent material: $\quad$ Dalles Formation (Ma et al., 2009), colluvium weathered from tuffaceous sandstone (Soil Survey Staff, 2012a)

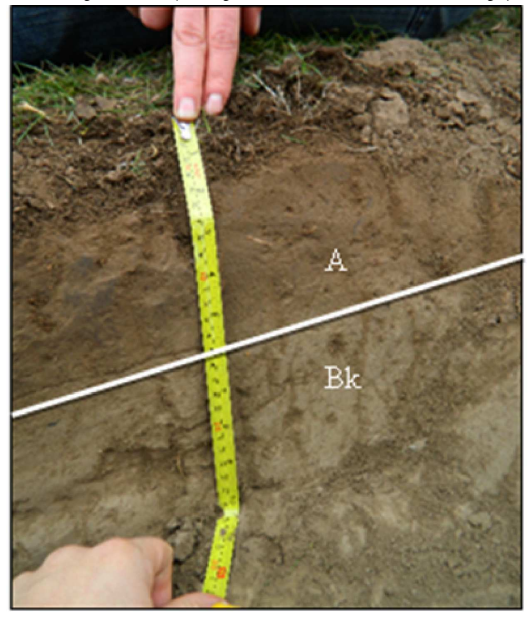

Described by:

D. Hansen, H. Hurtado and H. Whitney, November 11th, 2013

Remarks

Soil Pit Description The NRCS Soil Survey mapped this site as the Cherryhill Series (Ultic Argixeralf) (Soil Survey Staff, 2012a).There are no NRCS soil series in the competing series or associated series that note the calcic horizon. This soil is not representative of the Cherryhill Series.

A

0-10.5 cm (0-4 in.). Dark grayish brown (10 YR 4/2) when moist; dark yellowish brown (10 YR 4/4) when dry; sandy loam; massive fine subangular blocky structure; friable (moist), nonsticky and nonplastic (wet); $\mathrm{pH}=6.7$; clear straight boundary.

$\mathrm{Bk}$

10.5-22+ cm (4-8.6 in.). Brown (10 YR 5/3) when moist; grayish brown (10 YR 5/2) when dry; sandy clay loam; massive fine subangular block structure; extremely firm (moist), slightly sticky and slightly plastic (wet); $\mathrm{pH}=6.5$. 
Appendix D - 3. The Dalles soil sub-region: Volcano Ridge Vineyard

Field Classification: Ultic Haploxeralf

Location:

Elevation:

Topography:

Drainage:

Native Vegetation:

Parent material:

Described by:

Remarks

\section{Soil Pit Description}

A

BA

B1

Survey, 2013b)

Well-drained

Sandy mudflow

A. Busacca, 2007 of its clay content. nonplastic (wet).
Wasco County, Oregon

323 meters (1061 feet)

Northwest-facing, 22\% slope

(United States Geological

Ponderosa pine, Oregon white

oak, bluebunch wheatgrass

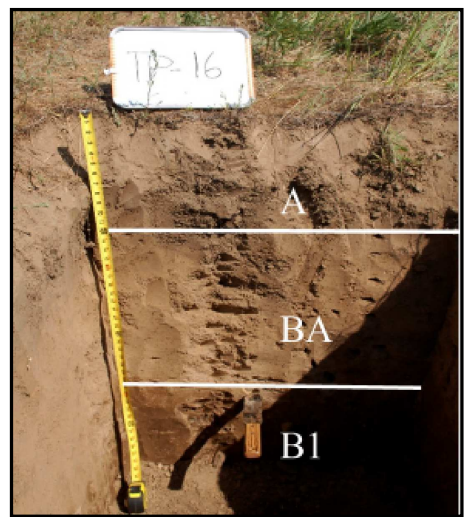

This soil pit was included to provide a typical soil profile for the Cherryhill Series. This series features sandy loam textures near the surface and sandy clay loam textures in the argillic (Bt) horizon. The Bt horizon is still moist at the end of May because

0-30.5 cm (0-12 in.). Very dark grayish brown (10YR 3/2) when moist; grayish brown (10YR 5/2) when dry; silt loam; weak fine subangular blocky structure; nonsticky and slightly plastic (wet).

30.5-81 cm (12-32 in.). Dark brown (10YR 3/3) when moist; brown (10 YR 5/3) when dry; dense; sandy loam; massive fine subangular blocky structure; friable (moist), nonsticky and

81-147 cm (32-58 in.). Dark yellowish brown (10YR 3/4) when moist; brown (10YR 5/3) when dry; dense; sandy clay loam; subangular block structure; thick and common clay films on ped faces and bridging grains. 
Appendix D - 3. Maryhill soil sub-region: Sunshine Mountain Vineyard

Field Classification: Calcic Haploxerolls

Location:

Wasco County, Oregon

Elevation:

303 meters (955 feet)

Topography:

Southwest-facing, $6.3^{\circ}$ slope (United States Geological

Survey 2013b)

Drainage:

Well-drained

Native Vegetation:

Bluebunch wheatgrass,

Sandberg bluegrass, sagebrush

(Soil Survey Staff, 2012a).

Parent material: $\quad$ Loess \& The Dalles

Formation (Ma et al., 2009;

Soil Survey Staff, 2012a)

Described by: $\quad$ S. Burns, D. Hansen and H.

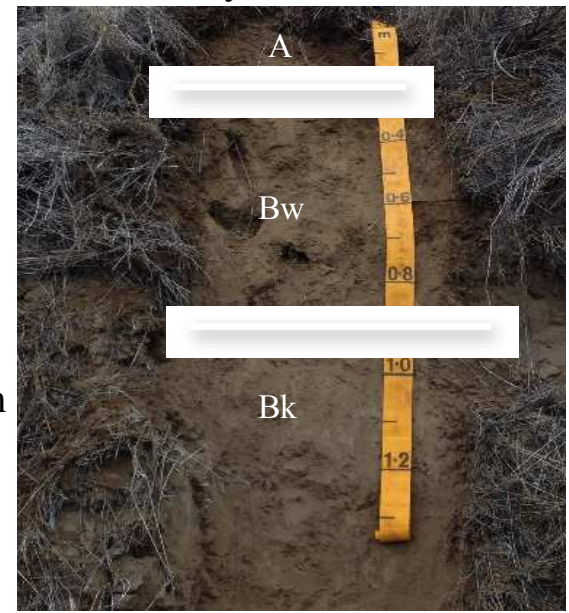

Hurtado, November 11th, 2013.

Remarks

The NRCS Soil Survey mapped this site as the Walla Walla

Series (Typic Haploxeroll) (Soil Survey Staff, 2012a). Field classification is not in agreement with the NRCS classification, and is likely the Chard Series (Soil Survey Staff, 2012a). The primary reason for the reclassification is the presence of the Bkhorizon.

\section{Soil Pit Description}

A

0-20 cm (0-7.9 in.). Dark yellowish brown (10 YR 3/4) when moist; brown (10YR 4/3) when dry; silt loam; weak fine subangular blocky structure; hard (dry), nons ticky and slightly plastic (wet); abundant crotovinas; $\mathrm{pH}=5.8$; clear wavy boundary.

Bw 20-90 cm (7.9-35 in.). Yellowish brown (10 YR 5/4) when moist; brown (10YR 5/3) when dry; silt loam; moderate medium subangular blocky structure; soft (dry), nonsticky and slightly plastic (wet); abundant crotovinas; $\mathrm{pH}=5.9$; clear wavy boundary.

Bk 90-200+ cm (35-79 in.). Brown (10 YR 5/3) when moist; grayish brown (10YR 5/2) when dry; silt loam; massive structure; extremely hard (dry); nonsticky and slightly plastic (wet); $\mathrm{pH}=$ 7.2. 